\title{
Effect of Individual Cultural Speeches on Accuracy and Cultural Content Knowledge of Intermediate Spanish Students
}

\author{
Guadalupe Madrid
}

Follow this and additional works at: https://researchrepository.wvu.edu/etd

\section{Recommended Citation}

Madrid, Guadalupe, "Effect of Individual Cultural Speeches on Accuracy and Cultural Content Knowledge of Intermediate Spanish Students" (2017). Graduate Theses, Dissertations, and Problem Reports. 7110. https://researchrepository.wvu.edu/etd/7110

This Dissertation is protected by copyright and/or related rights. It has been brought to you by the The Research Repository @ WVU with permission from the rights-holder(s). You are free to use this Dissertation in any way that is permitted by the copyright and related rights legislation that applies to your use. For other uses you must obtain permission from the rights-holder(s) directly, unless additional rights are indicated by a Creative Commons license in the record and/ or on the work itself. This Dissertation has been accepted for inclusion in WVU Graduate Theses, Dissertations, and Problem Reports collection by an authorized administrator of The Research Repository @ WVU.

For more information, please contact researchrepository@mail.wvu.edu. 
Effect of Individual Cultural Speeches on Accuracy and Cultural Content Knowledge of Intermediate Spanish Students

\author{
Guadalupe Madrid \\ Dissertation summitted to the College of Education and Human Services \\ at West Virginia University \\ in partial fulfillment of the requirements for the degree of \\ Doctor of Education \\ in \\ Curriculum \& Instruction \\ Joy F. Saab, Ed.D., Co-Chair \\ Sam Stack, Ph.D., Co-Chair \\ María Amores, Ph.D. \\ Erin Leatherman, Ph.D. \\ James Rye, Ph.D. \\ Department of Curriculum and Instruction/Literacy Studies
}

Morgantown, West Virginia

2017

Key words: Cultural Speeches, Accuracy, Planning Task, Oral Task, Guided Task Copyright 2017 Guadalupe Madrid 


\author{
Abstract \\ Effect of Individual Cultural Speeches on Accuracy and \\ Cultural Content Knowledge of Intermediate Spanish Students
}

Guadalupe Madrid

This quantitative study completed at an American university in Spring 2014 in intermediate Spanish classes measured if two individual cultural speeches (ICS tasks) had an effect not only on second language (L2) students' accuracy in Spanish during the oral presentation, but also their cultural content knowledge when answering the culture section of the final exam. The ICS task was presented in Spanish, orally without reading, so that students had the opportunity to speak Spanish and share cultural content knowledge with their classmates. The ICS task design was supported by The Robinson Cognition Hypothesis (2007), Ellis (2009) and Skehan and Foster's (1997) findings. The sample was composed of 57 Spanish 204 students of three different instructors. Each instructor had an experimental group that performed the ICS tasks and a control group that followed the regular program. One-way ANOVA and Mann-Whitney tests were the statistical methods used to analyze the dependent variable accuracy with three measures: global accuracy, verb accuracy and articles accuracy and the dependent variable cultural content knowledge in all control and experimental groups after the independent variable ICS task was applied. Because the variable accuracy has three measures, a MANOVA test was run to protect against error inflation. The result revealed that the ICS task had statistical significance in global accuracy ( $\mathrm{p}$ value $=0.032$ ) evaluated by error free sentences. The specific accuracy of verbs was significant ( $\mathrm{p}$ value $=0.006$ ) and evaluated according to appropriateness verb and conjugation. Cultural Content knowledge, as measured by the cultural questions of the final exam, was statistically significant $(\mathrm{p}$-value $=0.019)$. However, the specific accuracy related to the use of articles evaluated according to gender and number agreement was not significant $(p=0.271)$. These results demonstrated that performing two ICS tasks increases the number of error-free sentences and improves verb accuracy and cultural knowledge as measured in an oral presentation and cultural questions in the final exam. 


\section{Dedication}

For my son Francisco Javier,

who gave me the tenderness to remember him every day and the strength to endure his absence and continue life. 


\section{Acknowledgements}

I would like to express my immense gratitude to the two co-chairs of my committee: Dr. Joy Saab, former chair of the Department of Curriculum \& Instruction/Literacy Studies at West Virginia University, who trusted me and gave me the opportunity to earn a doctoral degree; and Dr. Sam Stack, current chair, who provided the support through the process of writing my dissertation and during adversities.

I am profoundly grateful to Dr. Erin Leatherman, of the Department of Statistics at West Virginia University, who was very generous with her time and knowledge throughout the statistical analyses of this investigation.

I express my thanks to Dr. Maria Amores, the coordinator of the Basic Spanish Program in the Department of World Languages, Literatures, and Linguistics at West Virginia University, who provided the linguistic orientation that allowed me to complete a defendable dissertation.

I also give my appreciation to Dr. James Rye, professor in the Department of Curriculum \& Instruction/Literacy Studies at West Virginia University, for being a member of my committee after his retirement.

I would also like to acknowledge the vital help of Spanish instructors Ana Laura Gil, Laura Llamas, and Susana Madinabeitia who each encouraged their students to participate in this study and followed the process required for this investigation to be successful.

I extend many thanks to Ms. Jean Dailey and Ms. Evangeline Cade for their willingness, patience, and hard work while proofreading my many changes to this manuscript. 
I would also like to thank Dr. Constinia Charbonnette, Director of Graduate Student Funding and Success at West Virginia University, who provided me precious support to accomplish the courses of the doctorate.

I really appreciate the help of Dr. Jane Cardi. I cannot forget the support provided by her when I started the doctorate.

Furthermore, I would like to mention two very important people: Dr. Bill Bryan and Ms. Dara Erazo, who provided extraordinary support in the final hours leading up to my defense, enabling my desirable achievement.

Last, but certainly not least, I am very grateful to Dr. Domingo Mata, my husband, who, with his research experience, taught me the perseverance to continue and provided the support needed to finish, and the desire to do it well. 


\section{Table of Contents}

ACKNOWLEDGEMENTS

LIST OF TABLES

LIST OF FIGURES
Page

iv

$\mathrm{X}$

xiii

Introduction

1

Background of this Study

1

Differences Between First Language and Second

1

Language in the Speech Process

Accuracy of Oral Production

4

Task Based on Oral Production

6

Cultural Content Knowledge

7

Foreign Language Syllabi Consideration

8

Problem Statement

9

Purpose 
Research Questions $\quad 11$

$\begin{array}{ll}\text { Limitation of this Study } & 13\end{array}$

Nomenclature and Definition of the Terms 15

$\begin{array}{lr}\text { Chapter II } & 18\end{array}$

Literature Review 18

Theories and Approaches in SLA that Support Output, 18 Task, and Focus on Form for Developing L2 Accuracy

Developing Accuracy in the Target Language through 30 Task-Based Oral Production

ICS Task Design According to the Research 
Random Selection of the Experimental and Control 48

Groups

Procedure

The task

Research Design

Instruments to Measure Accuracy

Instrument to Measure Cultural knowledge 
Knowledge

Research question \# 2 Discussion

Research Question \# 3 Discussion

\section{APPENDIX}

Appendix A

Poster Project Information and Procedure

Appendix B 
Appendix F Calendar of the ICS task

Appendix G

Questionnaire for the Instructors

Appendix $\mathrm{H}$

Demographic Information Instrument

Appendix I

Sample of the Final Exam 204

Appendix J

Instrument used for the Video Script

Appendix J1 -J57 Video Scripts Information of the Participants

128

\section{List of the Tables}

\section{Page}

Table $1 \quad$ Variables Studied in this Investigation

Table 2 Transformation Activity

Table 3

CTL Activity Exam

Table 4 Model of Second Language Acquisition Process

Table 5 The Cognition Hypothesis

Table 6 Task Type Pre-Planning Task and Post task

Table 7

Effect of Task Planning

Table $8 \quad$ Selection of the Groups 
Table 9 Timeline of the Study

Table 10 Design of the Experimental Study of Accuracy

Table 11 Design of the Experimental Study of Cultural Content

Knowledge

Table $12 \quad$ Global Accuracy Instrument

Table $13 \quad$ Specific Accuracy Instrument

Table $14 \quad$ Cultural Content Knowledge Instrument

English

Table 16 Questions From the Cultural Section of the Final Exam in

Spanish

Table 17 Information Entered in the SPSS

Table 18 MANOVA Test

Table 19

ANOVA Global Accuracy Descriptive

Table 20

Levene Test of ANOVA Global Accuracy

Table 21

ANOVA Test Global Accuracy

Table 22

Mann Whitney Test for Global Accuracy 
Table 23 ANOVA Verbs Accuracy Descriptive

Table $24 \quad$ Levene Test of ANOVA Verbs Accuracy 


\section{List of the Figures}

Page

$\begin{array}{lll}\text { Figure } 1 & \text { ICS task Semantic Map } & 14\end{array}$

Figure 2 Definition of Culture according to National Standards (1999)

Figure 3 The Iceberg Theory of Culture

Figure 4 Distribution by age of the Groups that Participated in this Study

Figure 5 Distribution by sex of the Groups that Participated in this Study

Figure 7 Distribution by Academic Level of the Groups that Participated in this Study

Figure 9 Boxplots for Global Accuracy

Figure 10 Histogram of ANOVA for verbs Accuracy

Figure 11 Boxplots for Verbs Accuracy 
Figure 14 Histogram of ANOVA for Cultural Content Knowledge

Figure 15 Boxplots for Cultural Content Knowledge

Figure 16 Historical overview that in essence illustrates some changes of the Curriculum, Learning Theories and Assessment 


\section{Chapter I}

\section{Introduction}

This quantitative study investigates the effect that two individual cultural speeches (ICS tasks) have on the accuracy of students' oral production, as measured by their performance in a poster project presentation during their fourth semester of Spanish. It also examines the effect of these ICS tasks on the acquisition of the cultural content knowledge, as measured by students' performance on the culture section of the final exam. The ICS task constitutes the treatment to be applied and the independent variable of the study whereas the poster project and the final exam are the post-tests to be used to measure the dependent variables accuracy and cultural content knowledge. The poster project (see Appendix A) is a task assigned to all intermediate Spanish 204 courses that consists of an inquiry into a cultural topic carried out by small groups of students and presented orally, to the class during the last week of the semester.

This introduction begins with a background of the study, and I overview key areas related to the research on accuracy in L2 learners' oral production that are relevant to this study, how cultural content knowledge is involved in foreign language teaching and critical to ICS tasks, and the language syllabus structure used specifically in this research. The chapter then presents the problem statement, purpose, limitations of this study, and defines key terms used in the study.

\section{Background of this Study}

\section{Differences Between First Language (L1) and Second Language (L2) in the Speech Process}

The most frequently used and cited mechanism of oral production for research is Levelt's model of first language (L1) speech production. Oral production according to Levelt s' (1995) 
model could be synthesized as follows: "people produce speech first conceptualizing the message, formulating or encoding its language, articulating it and finally, engaging in a selfmonitoring, which enables them to monitor their speech and reformulate it if/when necessary" (Ahmadian \& Tavakoli, 2010, p.36).

According to Wang (2014) “speaking in one's native language is an easy, fluent, and automatic process" (p.27). Native speakers' speech information flows from the Conceptualizer, to the Formulator to the Articulator for speech to be produced that is to say, "when a large unit of speech intention has been formed, the brain searches for a mapping between the pre-verbal message and specific target lexical nodes based on the relevant semantic and syntactic information in the lexicon" (p.27). A simple and specific example of lexical node after the preverbal message would be "a verb" (e.g. play), the encoded morphology could be "the time of the verb" (e.g. past time: played) and these two elements activate phonetic encoding in order to articulate speech (Levelt, 2001 as cited by Wang, 2014, p. 28). There is a similarity in L1 speech production and L2 speech production (after certain level of proficiency) regarding "a parallel and automatic process," it was demonstrated that "once the first syllable of a word is phonologically encoded, its articulation can start in the articulator, and the small units of each phonetic word are articulated," and subsequently, "we perceive the speech" (Kormos, 2011, p.41; Wang, 2014, p. 28). A relevant aspect of speech production is the memory store called "long term memory," which contains, both episodic and semantic memory. Semantic memory is related to linguistic concepts and has a hierarchical structure that involves three levels: semantic, syntactic and morpho-phonological information. L1 speech production procedure links the meaning and the mental representation of the pre- verbal message in the hierarchical structure, without conscious awareness through implicit knowledge, it is an automatic procedure because L1 has enough 
working memory (Kormos, 2011). It explains the "Procedural Memory" which is linked to the automatic processing language of the L1 and "concerns the control of long established, motor and cognitive skills or habits (Wang, 2014 p.28). Unlike L1 speech production, which is an automatic skill, the L2 speaking process presents a host of difficulties. One of the reasons is that 12 the speakers have a limited working memory that slows the speech procedure particularly in the articulatory phase. As language learners acquire some level of proficiency in the phonetic encoding of the target language, articulation becomes more automatic (Wang, 2014). Wang also claimed that L2 speech production is slower than L1 because the hierarchical process of linking the preverbal message with its representation requires greater effort. Kormos (2011) pointed out that L2 learner depends on their "declarative memory" where explicit rules, as opposed to implicit procedure, are stored. Declarative memory requires conscious awareness in order to apply the rules. L2 speakers also face the difficulty of resources deficit especially during the conceptualization stage, when they may encounter a gap in the mental lexicon, when this occurs, learner must revise and re-conceptualize in order to match the speech with the available resource, for example "finding alternatives to express ideas" Wang (2014, p.31). Finally, Ullman (2001) as cited by Kormos (2011), pointed out that a difference between L1 and L2 speeches processing was presented from neuro-imaging research and it argued that in L2 "grammar is stored in a brain region different from the area which is responsible for the processing of automatized rules of grammar" (p.42). However, to establish this difference between L1 and L2 based on neuroimaging research, another "modified and extended model of oral L2 production" (p.42) is needed. 


\section{Accuracy of Oral Production}

In recent research on second language acquisition (SLA), there has been greater attention paid to three measurements of spoken language: complexity, accuracy, and fluency (CAF), which are characteristics that define oral production. Skehan and Foster (1999) defined complexity as" the capacity to use more advanced language with the possibility that such language may not be controlled so effectively and this may also involve a greater willingness to take risk" and fluency was defined as "the capacity to use the language in real time" to emphasize meanings on more lexicalized system. Accuracy refers to " the ability to avoid error in performance, possibly reflecting higher levels of control in the language, as well as a conservative orientation, that is, avoiding of challenging structures that might provoke error" (p.96). Similarly, Barrette and Salaberry (2011) defined accuracy as appropriate uses of grammatical forms during language production.

A significant issue that continues to challenge language researchers and educators is how to ensure that learners develop CAF in oral production (Housen \& Kuiken, 2009) and task based instruction has been proposed for that purpose (Barrette \& Salaberry, 2011). Skehan (1998) defined a task as an activity in which 1) meaning is primary, and learners are not given other people's meanings to regurgitate; 2) there is some sort of relationship to comparable real world activities; 3) task completion has some priority; and 4) the assessment of the task is in terms of outcome.

There has been a discussion in the SLA research as to the effects of different types of task characteristics (e.g., pre-task planning, cognitive demand of the task, task repetition) on CAF. To 
date, research findings (Ellis, 2009; Robinson \& Gilabert, 2007; Skehan \&Foster, 1997;

Ahmadian \& Tavakoli, 2010; Ortega, 1999) claim the following:

1. Repetition of the same task (or a very similar task), pre-task planning and tasks based on concrete or familiar information and public presentations lead to greater fluency and accuracy.

2. Tasks with high cognitive demand, pre-task planning, narrative tasks, guided careful online planning, form-focused feedback and form-focused guided planning (where students notice a targeted structured positively), and post task condition (e.g. public performance), impact accuracy.

3. Complexity is enhanced by tasks with high cognitive demand, tasks requiring information manipulation, task repetition (lexical complexity), pre-task and guided careful online planning, and form-focused guided planning.

This study focuses on the accuracy component of CAF examined during an oral poster project presentation for two reasons. First, accuracy (or correctness) is the most observable part of CAF because is measured by errors or "deviation from the norm usually characterized as errors" and, it is used to compare the language learner's accuracy proficiency to native-like accuracy according to the errors made (Housen \& Kuiken 2009, p.3; Palloti 2009). Second, accuracy is a component of the "rival claim" between The Cognition Hypothesis and Trade-off Hypothesis about which characteristic of the task (task difficulty or task condition factors) most impacts CAF. The Cognition Hypothesis claims that task should be sequenced in a manner of increasing cognitive complexity based on three components: complexity, conditions and difficulty and along two dimensions: resource-directing and resource-dispersing to promote more accurate and complex speech production (Robinson \& Gilabert, 2007). On the other hand, the 
Trade-off Hypothesis argues that accuracy and complexity are not function of the task difficulty, as Robinson's Cognition Hypothesis maintains, but rather of the task conditions such as planning task and post- task (Skehan \& Foster, 1997). The ICS task, proposed in this study as the independent variable, involves elements of these two hypotheses through cognitive demand and planning. Accordingly, a summary of the effects of task characteristics on accuracy in oral production follows.

\section{Tasks Based on Oral Production}

According to Ahmadian and Tavakoli (2010), task planning is indispensable to language production: "When there is no time restriction, learners can take time to attend to form and to formulate more accurate structures and correct the inaccurate ones” (p. 37). Rahimpour and Hazar (2007) found that a variation in task types presents a different L2 performance in oral production in terms of CAF. Thus, the finding showed that accuracy is greater when L2 learners perform activities related to the There and Then (where students used past time) rather than the Here and Now (where students used present time) because more complex tasks "will lead learners to stretch their interlanguage resources" (Discussion, para. 1). Ellis (2009) showed the effect of pre-task planning (with and without rehearsal) on the fluency, complexity and accuracy of L2 oral performance in a meta-analysis. The results revealed a wide range of different effects on CAF; however, rehearsal (repetition) was found to be beneficial to accuracy, which is the concern of this investigation.

The ICS task involved various elements previously studied by researchers: the first element was the pre-task that consists of planning the task (Ellis, 2009; Ortega, 1999); the second element was the post-task which was the oral presentation (Skehan \& Foster, 1997); the 
third element was the strategic task (Ellis, 2009), in which students received orientation by the instructor about the form and content of the task; and the fourth was the cognitively demanding element because the topic could be unfamiliar (Robinson \& Gilabert , 2007). The strategy of the ICS task was designed to improve not only speaking, but also cultural content knowledge. The role of culture in second language teaching and learning is discussed in the following section.

\section{Cultural Content Knowledge}

Language and culture are inextricably interrelated (Schulz, 2007, p.9).

The introduction of the National Standards ACTFL (2006) in the late 20th century presented five goals in the teaching of foreign languages entitled the five Cs: communication, culture, connections, comparisons, and communities. These standards began influencing foreign language education in grades $\mathrm{K}-12$ and were designed to guide learners toward becoming productive contributors and participants in a linguistically and culturally diverse society (Moeller \& Nugent, 2014). The cultural components in the foreign language field commonly include three components: the practices, products and perspectives that the society accepts, performs and creates respectively (National Standards ACTFL, 2006).

The culture goal refers to the expectancy that students gain knowledge and understanding of other cultures and involves two standards. In standard 2.1, "students demonstrate an understanding of the relationship between the practices and perspectives of the culture studied," and in standard 2.2, "students demonstrate an understanding of the relationship between the products and perspectives of the culture studied" (National Standards ACTFL, 2006, p.50, 51). These standards have developed not only out of a desire to promote cross-cultural understanding including positive attitudes toward other cultures and the lessening of ethnocentrism, but also the 
pedagogical vision of what students know and are able to do with another language (National Standards ACTFL, 2006).

The increasing focus on culture in the foreign language classroom is reflected in syllabus design that integrates language and culture, such as the syllabus used in the courses in this investigation. The syllabus also involves the poster project that is one of the post-test of this study. Therefore, it is pertinent to present some considerations regarding foreign language syllabus design.

\section{Foreign Language Syllabi Considerations}

According to Nunam (1988), in the 1960s the foreign language syllabus was crafted in grammatical terms, and language learning consisted of memorizing "a finite set of rules that could be combined in various ways to make meaning". However, there was a movement away from grammatical syllabi to communicative syllabi in support of new research and theories in SLA, such as Krashen's Natural Approach, in the 1970s. By following the natural approach, the syllabi were based on communicative activities related to real context topics, which promoted subconscious language acquisition through the natural order rather than conscious learning based on instruction. Most contemporary language syllabi keep the communicative design and are a combination of a situational syllabus and a task-based syllabus. A situational syllabus is based on real or imaginary situations where students are engaged in activities that encourage them to communicate. A task-based syllabus involves a task where the learner has "the goal of drawing on resources to complete some piece of work" through a cognitive and communicative process (Nunam, 1998, p.56). 


\section{Problem Statement}

This section will explain previous research related to speaking and culture which support the variables studied in this investigation and will also state the research questions, the set of hypotheses, the limitations of this study, and a definition of terms related to the field of this investigation.

Krashen (1982) posited that "real language acquisition develops slowly and speaking skills emerge significantly later, even when conditions are perfect, and the best methods are those that supply comprehensible input, in low anxiety situations containing messages that students really want to hear" (What the Three Approaches Have to Say About Methods, para.1) However, more recent approaches have highlighted the fundamental role of output in second language acquisition as well as the importance of providing learners with tasks that require them to pay attention to form and meaning (Swain, 1985;Williams 1992). Ortega (1999) found that in a meaningful context, pre-task planning induces the students to pay attention to the form. Moreover, much current research on task-based performance has shown that different types of planning promote learner performance in different areas, that is, fluency, complexity, and accuracy (Skehan, 2014; Wang, 2014). Robinson (2009), for his part, claims that pedagogic tasks should be increased in cognitive complexity to promote accuracy and complex speech. In summary, for over two decades, studies have shown that manipulating the task generally improves learners' oral production performance, but, to date there are still significant questions to be answered. For example, Ellis (2009, p.505) asked: "What effects accrue from planning for learners of different proficiency levels in comparison with native speakers? Robinson (2007) suggested continuing future research on the "effect of task complexity on learning and performance" (p.211). 
The National Standards (ACTFL, 2006) affirmed, "in the process of foreign language learning, the mastery of the second language occurs when L2 students acquire mastery of the culture" (p.27). Unfortunately, the impact of the standards has not been assimilated across university levels (Allen, 2009). It was observed (MLA Ad Hoc, 2007) that foreign language curriculum at the university level generally starts with language learning in lower division courses and moves towards content-based courses in upper division courses that focus mainly on literature and civilization. The authors of the Modern Language Association Report advocated for a broader and more coherent curriculum in which language, culture, and literature are taught as a continuous whole throughout the different levels of language classes. According to Byrd et al (2011), historically, culture has not been given the prominence it deserves within language curriculum, methodologies, and instructional techniques. A survey conducted by the Social Science Education Consortium in 1999 revealed that cultural lessons are not well integrated with language instruction and lack the depth that would be needed to truly illustrate the relationship between culture and language (Schulz, 2007). The present study is an attempt to fill in those gaps, as stated in the following sections of this chapter.

\section{Purpose}

Tasks have a purpose. For example, Vygotsky (as cited by Lee, 2012) claimed that in the foreign language classroom, interactions between learners, learners and teachers, and learners and course materials provide opportunities for images, beliefs, stereotypes, and representations to come into contact with each other and thus to be potentially reassessed, reorganized, and subsequently internalized. Thus, the ICS task proposed in this study is an oral skills task that is perfectly applicable in the classroom because it can be added to the syllabus and assessed in the 
oral activities category so that students improve oral proficiency. Students can be engaged in this activity as the procedure is guided, and they receive sufficient time for planning the ICS task.

The investigator designed two ICS tasks as the independent variable. These ICS tasks were presented to the class during the last five weeks of the semester (before the poster project presentation) and were related to one cultural topic. The objective was twofold: first, to measure the dependent variable accuracy (in terms of global accuracy, verb accuracy, and article accuracy) during the poster project presentation and second, to assess the acquisition of cultural content knowledge, as measured through the points earned on the cultural section of the final exam. Table 1 presents the three variables formulated.

Table 1

Variables Studied in this Investigation

\begin{tabular}{cc}
\hline Independent Variable & Dependent Variables \\
\hline ICS Tasks & Accuracy \\
& Cultural Content Knowledge \\
\hline
\end{tabular}

\section{Research Questions}

As was explained before, the strategy of using an ICS task in this study is based on the findings of various researchers who suggested that by creating pre-task planning (Ellis, 2009) and by increasing the cognitive complexity in tasks (Robinson \& Gilabert, 2007), L2 students should be more accurate in language production. Also, it was pointed out at MLA Ad Hoc (2007) that "more students will continue language study if courses incorporate cultural inquiry at all levels" (p.4) consequently, in this study three main research questions were formulated: 
1. Does a set of two ICS tasks in the experimental group as opposed to the absence of these tasks in a control group result in a statistically significant difference in accuracy in the oral poster presentation?

2. Does a set of two ICS tasks in the experimental group as opposed to the absence of these tasks in a control group result in a statistically significant difference in the cultural content knowledge as measured by the final exam?

3. How, if at all, does the cultural content instruction differ across sections and what effects do these potential differences in instruction have in this study? This research question is a qualitative piece added to this investigation that was analyzed through a questionnaire given to the instructors.

Therefore, in this study it was hypothesized that a set of two individual cultural speeches (ICS task) related to Hispanic cultural topics improves not only accuracy, but also the cultural content knowledge in the Spanish language of intermediate Spanish students.

The appropriate set of hypotheses for this study is as follows:

For Accuracy

1) Ho: There is no effect of the ICS task on L2 learners' accuracy in oral poster presentations.

2) H1: There is an effect of the ICS task on L2 learners' accuracy in oral poster presentations. For Cultural Content Knowledge

1) Ho: There is no effect of the ICS task on L2 learners' cultural content knowledge in the final exam.

2) H1: There is an effect of the ICS task on L2 learners' cultural content knowledge in the final exam. 


\section{Limitations of this Study}

There were two main limitations in this study. A first limitation was that there are not universal instruments to evaluate oral production in terms of accuracy. The instruments used in this study were taken from previous linguistics investigations, such as the instruments used by Skehan and Foster (1999) and Rahimpor and Hazar (2006), which are presented in tables 12 and 13 in page 56. These were modified and applied to measure accuracy in oral production. Accuracy was evaluated in terms of both global accuracy and specific accuracy. Global accuracy refers to the number of error-free clauses out of the total number of clauses. For specific accuracy, grammatical items, article and verb use, were measured. An example of using this adopted measure is represented in a study of Rahimpour and Hazar (2006) that measured the effect of a planning time task and the interactional feedback on accuracy, complexity and fluency. The accuracy was achieved by calculating the percentage of error free-clauses in the total numbers of the clauses, which is very similar to the accuracy instrument used in this investigation. The data were placed into SPSS for statistical analyses that revealed a high average of accuracy when student performed the planning time task and feedback condition task. Another example is a study led by Skehan and Foster (1999) with 40 part time students of English as a foreign language at a college. This study measured the effect of tasks planning in CAF by using a similar instrument to the instrument used in this investigation based on error-free clauses. The results revealed that narrative tasks had a significant effect in accuracy. These two studies demonstrated effectiveness of measuring accuracy through error-free clauses in planning tasks that are similar to the ICS task applied in this investigation. 
A second limitation is related to the criteria used to measure cultural content knowledge, which leaves out much information about the cultural content presented in class and learned by students. It seems that there is a new tendency to measure cultural content knowledge that replaces the short answer questions. Regarding this emerging tendency, Schulz (2007) claimed that "culture is not seen as set of static factual information, but as a process that is dynamic, developmental, and ongoing and that has cognitive as well as behavioral and affective dimensions" (p.12).

To summarize chapter I, figure 1 is a semantic map that proves the elements measured and activities completed by L2s learners involved in the ICS task. It, also shows the oral task approach and the syllabus-task approach, as a theoretical framework, that is elaborated in the next chapter to support the variables investigated.

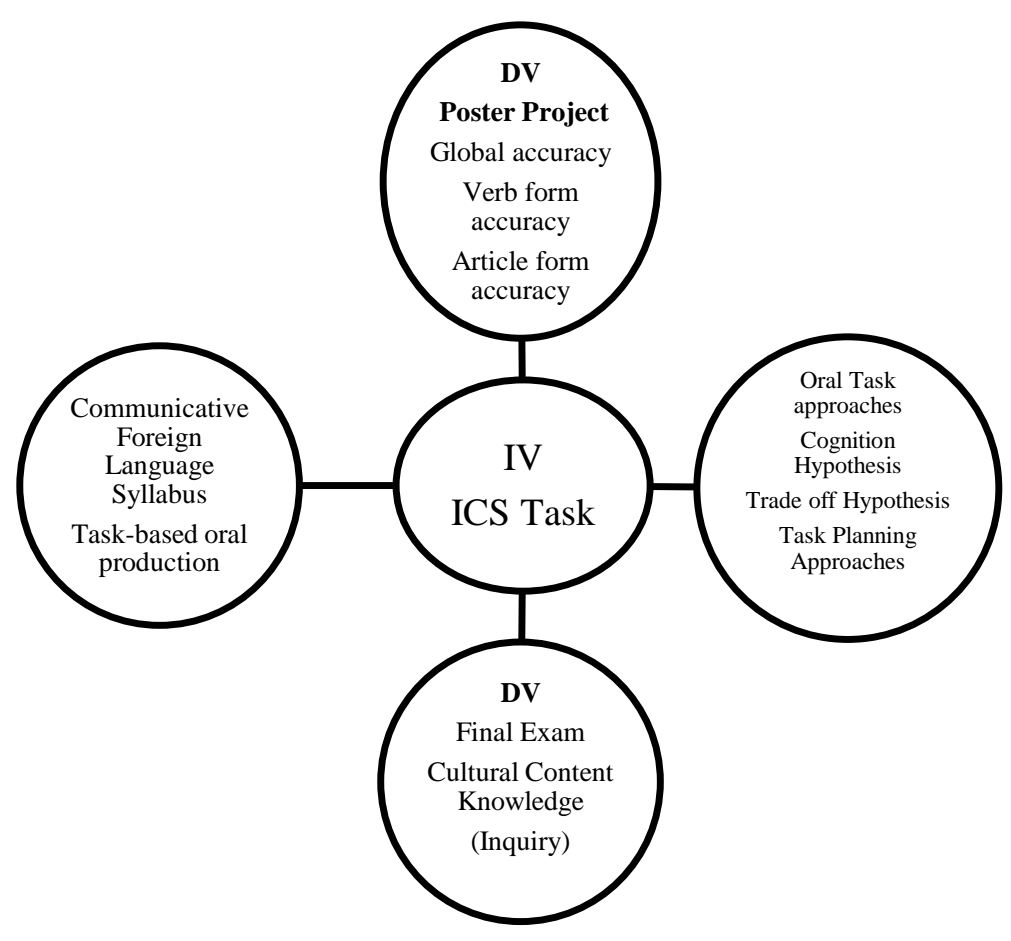

Figure 1. Semantic Map. IV= independent variable. DV= dependent variable. 


\section{Nomenclature and Definition of the Terms}

The following definitions are provided to ensure uniformity and understanding of these terms throughout the study:

Applied linguistics. It refers to the study of a second foreign language learning and teaching (Richards and Schmidt, 2013).

CAF. Complexity, accuracy, and fluency have proved useful measures of second language performance (Skehan, 2009).

Cultural content knowledge. In this study, is considered by the knowledge about culture that L2 students are expected to have acquired by the completion of the course.

Clause/ sentence. In this study, the term clause and sentence are used interchangeably.

Explicit learning. Is defined as the learning of information in a conscious and often in effortful manner (VanPatten \& Williams 2007).

Fossilization. Is defined as cessation of learning, in spite of rich exposure to input, adequate motivation to learn, and abundant opportunity for communicative practices (Han, 2004).

Grammar form. A grammatical element of the language.

GTAs/instructor. Graduate Teaching Assistant and Spanish instructor are used interchangeably in this study.

ICS task. The individual cultural speech that is proposed as a task in this study that produce an effect in oral production. 
IL/interlanguage. Is related to the path between the source or native language and the target or second language (Master, 1987).

Input. It refers to the language that a learner is exposed to in a communicative context (Gass and Makey, 2007).

Inquiry. Is the act of asking for information/ Is an official attempt to discover the facts of something (Cambridge Dictionary).

Implicit learning. Is the learning of information without the intent to learn it, usually in a unconscious manner.

L1. Related to the learner's first language (mother tongue).

L2. Related to the learner's second language (target language).

Language learning. Is an intentional process that results in conscious metalinguistic knowledge (Krashen, 1982).

Language acquisition. Is an incidental process that results in tacit linguistic knowledge (Krashen, 1982).

MLA. Modern Language Association.

Metalinguistic. L2 students reflect upon the language learned and internalize their linguistic knowledge (Swain, 1993).

Negotiation for meaning. Is the attempt made in a conversation to resolve a lack of understanding (VanPatten \& Williams 2007).

Noticing. When L2 learner notices their gap in their Knowledge (Swain, 1993). 
Output. The language that L2 produce and seem to have a significant role in the development of syntax and morphology (Zhang, 2009).

Oral production/ speech production. In this study, are interchangeable terms. Relate to the Spanish spoken by L2 students when performing the ICS task or in the completion of any other spoken task.

PI. Processing Instruction Approach.

SLA. Second Language Acquisition.

Working memory. This term refers to the individual capacity of the learner for temporarily maintaining language information in memory for executive function (Payne \& Whitney, 2002). 


\section{Chapter II}

\section{Literature Review}

This literature review presents, first, a brief summary of SLA research and its proposed methodologies. Second, I review research on task-based oral production and its effects on accuracy in oral performance. Third, recent insights that not only promote language and culture as a whole, but also promote inquiry into culture topics so that students progress in their knowledge of culture content are examined. Fourth, even though syllabus design is not a variable studied in this investigation, it is pertinent to review contemporary language syllabi because they constitute the curricular element that supports the task design to be applied in this study.

\section{Theories and Approaches in SLA that Support Output, Task, and Focus on Form}

\section{for Developing L2 Accuracy}

Over the course of time, foreign language teaching methodology has moved from dogmatic points of view to a more eclectic position utilizing a variety of approaches that have influenced contemporary language teaching (Griffiths and Parr, 2001). Beginning around the time of the Second World War, the predominant approach to language teaching was Audiolingualism (ALM), based on the Behaviorist Theory (Richards \& Rogers, 2013). The Audiolingual Method attempted to create native-like speakers through extensive repetition and a variety of elaborate drills in a way that made responses automatic and habitual. The acquisition of the language was based on the replacement of first language habits with second language habits. ALM relies on assumptions that language learning is related to habit formation, so repetition, imitation, and reinforcement were key. Demirezen (1988) affirmed: "the Behaviorist Theory stresses that human and animal learning is a process of habit formation. A highly 
complex learning task, according to this theory may be learned by being broken down into small habits "(p.136). Also, "all learning is the establishment of habit as the result of reinforcement and reward "(p.137). Therefore, the Behaviorist Theory proposed "that language is controlled by the consequence of behavior" (p.137), supporting the idea that language is like any other habit and new habits must be instilled in the learner to achieve L2 proficiency.

With ALM (see Table 2) the instructor gave the students activities where students had to substitute or transform the input quickly and accurately (Lee \& VanPatten, 2003, p.9).

Note the following example of a transformation exercise using the ALM approach:

\section{Table 2}

Transform Substituting the Present to the Past

Present Past
1) I eat
1) I ate
2) He goes
2) He went
3) We sleep
3) We slept

Note. This example was adapted from Transformation Activity. Lee and VanPatten (2003, p.10).

Students did well in the transformation activity shown in table 2. However, according to Lee and VanPatten (2003), this type of task does not provide the students opportunities to communicate in a meaningful or real context that involves the exchange of messages. The nature of ALM instruction was such that the students did not need to know what they were saying, just that what they were saying was correct. According to Lee and VanPatten (2003): 
Learners must be given the opportunities to construct communicative interactions in the classroom as they would outside the class to interpret, express and negotiate meaning. In short, to move students beyond the role of recipient, we must give them both the responsibility and the appropriate materials (p.10).

Since the Audiolingual Method proved to accomplish less than it had promised, “communication" began to play a central role in language pedagogy. To date, SLA approaches have continued to emerge over time because one of the most controversial aspects of language teaching methodology has been determining what exactly is necessary to encourage students in the classroom to communicate in the target language (Griffiths \& Parr, 2001). In recent times, the methodology has moved toward a goal of inculcating students with communicative competence, which includes not only grammar and lexical competence, but also experiential activities focused on sociolinguistic and discourse competence (Canale \& Swain, 1980). Furthermore, modifications in the roles of teachers and students have influenced the dynamic in the classroom from teacher centered, in which teachers control the subject matter and the social interactions in the class, to student centered, in which students play the role of active learner through interaction and communication in the target language during class time (Lee \& VanPatten, 2003 p.10).

After the Audiolingual Method, Communicative Teaching Language (CLT) came into vogue, and instructors began to provide students with opportunities for communication. Students started to use the language to interpret and express real-life messages. The transformation activities used in ALM (see Table 2) changed to more open-ended activities, illustrating the shift from ALM to CLT (Lee \& VanPatten, 2003). 
Lee and VanPatten (2003) stated that the instructor in CLT provided L2 students with opportunities to interact and practice (see Table 3). The CLT approach focuses on L2 students working in pairs or small groups so they can communicate through interaction and negotiation of meaning in the target language. Early attempts at CLT approach involved teacher-led conversations (see Table 3) with open-ended questions that engaged students in using the second language. However, even though the conversation had a much more natural feel, they were not fully communicative because the instructor had still an authoritative role as shown in table 3; this exchange is a practice of the past tense.

Table 3

CLT Activity Example

Instructor: What did you do last week?

Raul: I went to Florida. To the beach. We ate in a lot of restaurants

Instructor: That sounds like a fun week. Gloria, what did you do last week/

Gloria: Not much. My husband and I read. We watched TV.

Instructor: Did you go to Florida?

Gloria: No.

Instructor: Did you go to Florida last week John?

John: Me? No. I went to Bloomington to visit my parents.

Note. A piece of a conversation between instructor and L2 students taken from Lee \& VanPatten (2003 p.13). 
According to Williams (1985), CLT was the method that enhanced language learners' communication more than previous methods that geared instruction primarily toward the learning of linguistic structures. However, despite the goal of CLT to afford students a more central role in their learning, in the activities presented in both ALM and early CLT methods, the instructor assumes an authoritative role, and students repeat (see Table 2) or merely answer questions (see Table 3), (Lee \& Van Patten, 2003 p. 10-11).

Krashen (1982) stated that these language teaching methods failed because they were "not theories of language acquisition "(Interaction Among Approach to Practice, para. 7) rather, they were "theories of the product of the language." Thus, the concern involved in these language teaching methods was about students competence, through application of material in the classroom, and not about "a theory of how the adult got that competence" which is the most important idea of the process of acquisition (Interaction Among Approach to Practice, para. 8). In the second half of the 20th century, a "new dynamic language class" emerged with a new theory proposed by Krashen (Lee \& VanPatten, 2003), and the relationship of theories to practice showed that the solution to language teaching is not based on using "expensive equipment, exotic methods, or sophisticated linguistic analyses" (The Relationship of Theory to Practice, para 2), but on full utilization of the language for real communication by the learners, and also on theories on how a language is acquired.

Krashen's Theory of Second Languages Acquisition (1982) consists of a set of five hypotheses:

1) The Acquisition Hypothesis, which presents two systems activated in the learning process of a second language: a) the acquired system and b) the learned system. The acquired 
system is the product of a subconscious process very similar to the process that children use when they acquire their first language. This learning process requires meaningful interaction in the target language and natural communication in which speakers are concentrated not on the form of their utterances, but on the communicative act. The learning system is a conscious process that pays attention to the use of grammatical rules.

2) The Natural Order Hypothesis points out that learners acquire certain grammatical structures earlier than others because the acquisition of grammatical structure follows a predictable order.

3) The Monitor Hypothesis posits that it is the learned system that causes the learner to "monitor," or regulate, his or her production to alter the output of the acquired system before or after the utterance is spoken. The monitor requires three conditions in order to operate: a) time, in order to use conscious rules effectively, b) attention to the correctness of the form, and c) knowledge of the rule.

4) The Input Hypothesis predicts that natural, communicative, and comprehensible input facilitates L2 acquisition, as opposed to classroom exercises that aim to teach the target structure. "Comprehensible input" is defined as input that is just above the learners' current linguistic ability (Krashen, 1982). This hypothesis is related to the concept that language are acquired and not just learned. In order for acquisition to happen learners have to receive input just beyond their current level or i+1 (Nolan, 2001). Krashen's theory (1982) that is currently most prominent in the field of SLA claims that input is the greatest sole determiner of language acquisition.

5) The Affective Filter Hypothesis states that attitudinal factors are related directly to acquisition; these affective variables are motivation, self-confidence, and anxiety. A revision of 
Krashen's Theory done by Schutz (2005) stated that "low motivation, low self -esteem, and debilitating anxiety can combine to raise the affective filter and form a mental block that prevent comprehensible input from being used for acquisition. In other words, when filter is up it impedes language acquisition" (p.3).

Krashen (1982) maintains that language acquisition does not require extensive conscious use of grammatical rules and "the best methods are therefore those that supply comprehensible input in low anxiety situations containing massages that students want to hear" (p.7).

Lee and VanPatten (2003), based on Krashen's theory, developed the Processing Instruction Approach (PI). In this approach, the input is structured, meaning that the input is manipulated and prepared to highlight particular grammatical features (Fang, 2010). The way that learners naturally attend to the input has been describe by Lee and VanPatten (2003). First, learners tend to focus on words as the primary source of meaning, rather than grammar. Second learners attend more to the lexical items in initial position of the sentences. For example in the sentence: yesterday I talked to my brother learners will glean pastness from the adverb yesterday rather than from the morphological ending ed.

In order to maintain L2 students' focus on the grammatical form in the input Lee \& Van Patten (2003) developed the following guidelines:

1) Teach only one thing at a time, that is to say, each grammar rule must be presented piece by piece. Maximum efficiency is achieved when only one form and one function are the focus at any given time (e.g. the third person of the present tense). 
2) Keep meaning in focus through activities where L2 learners must attend to each utterance and make the connection between the form and the meaning in order to complete the task.

3) The L2 learner must do something with the input (e.g. complete true false activities, provide at least one word response, etc.) that requires them to comprehend the input.

4) Use both oral and written input. Because of individual differences in acquisition, some L2 learners benefit more from aural input while others benefit more from written input.

5) Move L2 students from sentences to more extended discourse; it is important to begin with shorter sentences because longer sentences overwhelm the learner and cause them to dismiss the form (VanPatten, 2003; Fang, 2010).

6) Keep the learner's processing strategies in mind; "Learners should focus attention during processing on the relevant grammatical items and not on other element of the sentences," e.g. avoiding the use of temporal adverbs in sentences so that L2 students pay attention to the form of the verb rather than to the lexical items (Lee \& VanPatten, 2003, p. 158).

There are three components in the process of second language learning: I) input and intake, II) the developing system, and III) output (See Table 4). Input has a crucial role in acquisition. The initial stage involves both input and intake, which is necessary for the comprehension of the form, which ultimately builds the form-meaning connections needed for students to develop an implicit linguistic system (Fang, 2010). Input has an inherent "communicative value" which means that not only the lexis but also the form encode the 
meaning needed for communication. Intake, on the other hand, is the linguistic data the learners attend to in the input. The more communicative the input is, the more intake occurs, which subsequently leads to the development of the linguistic system so that acquisition of the second language takes place (Lee \& VanPatten, 2003).

Table 4

Model of Second Language Acquisition Process

\begin{tabular}{ccc}
\hline I & II & III \\
INPUT -INTAKE- & DEVELOPING SYSTEM- OUTPUT \\
Listening / Reading & Acquisition & Speaking / Writing \\
& ICS task (independent \\
& variable investigated)
\end{tabular}

Note. Modified from Fang (2010) based on VanPatten (1995)

Payne and Whitney (2002) claimed, "input alone is not sufficient to obtain high level of proficiency development in a second language" (p.7). Harley (1993) as cited by Payne and Whitney (2002) pointed out that L2 students exposed to rich input present weaknesses in grammatical accuracy. It is convenient to clarify that input and output are differences process. In the input processing L2 learners make "form-meaning connections" and take the linguistic data called "intake" that is hold in the "working memory" (VanPatten 2003, p.31). Regarding to output, Terrell stated (as cited by Lee \& VanPatten, 2003) that output-process is the ability of learners to access their implicit linguistic system. Therefore, L2 learners need input to "build a 
developing system but also opportunities to create output in order to work on fluency and accuracy" (Lee \& VanPatten, 2003, p.170).

Swain (1985), in her Output Hypothesis, claimed that despite years of exposure, input alone does not assure that L2 students will achieve near-native proficiency. Her conclusions came as a result of extensive research with a French immersion program in Canada in which students had receptive knowledge of French, but not productive knowledge because of a lack of output. Furthermore, producing the target language serves as the trigger that force the learner to pay attention to the linguistic structure and lexical items in order to produce his or her intended meaning. Swain showed that there are three mental processes connected to producing language. The first is the noticing function: Swain maintained that it is the function of "noticing" during output that helps L2 students notice the gap between what they want to say and what they can say. Language learners realize what they do not know, or only partially know, when they attempt to use language beyond their productive level. Thus, L2 students know what they want to say, but are unable to communicate it. The second mental process is the hypothesis testing function: here, the L2 students receive feedback by reformulating their statement or through interaction with the teacher and peers resulting in more noticing. The last mental process is the metalinguistic function: the L2 students reflect upon the language learned and internalize the linguistic knowledge. Swain (2000) completed a pilot study with 48 students from French immersions program. Students were given three different diptoglosses during school term (a diptogloss is a text that is read to the students and then they work in groups writing down some words, and reconstruct the text). The diptogloss was applied in three sessions with a week apart. The diptogloss was read twice, the first time students just listened and the second time students took notes and then worked in pairs to re-construe the diptogloss. Once the participants started 
working, the talk of each group was transcribed. The student used tools at their disposal (dictionaries, books) teacher noticed students dialogued about they did not know. These results were analyzed and indicated that the dictogloss create opportunity to metatalk (which is the metalinguistic function of output used by learned in order to reflect on their target language use). The metatalk has an effect in the interlanguage because students noticing the gap between they want to say and they are able to say.

Furthermore, Williams (1995) stated that, "many researchers and teachers have begun to wonder if it is enough to provide students with rich, varied and interesting input and opportunities to interact and practices. Williams posited "it is probably that some degree of focus on form could lead to improved more accurate performance" (p. 12). Williams affirmed that even though L2 students in the CLT Canadian Immersion Program:

have had masses of comprehensible input and lots of opportunities to communicate about high interest material in a comfortable environment. They are given ample time and opportunity to formulate and test out hypotheses. So what could be wrong? Why do they fail to come even close to native speaker standards of accuracy in so many areas, even after years in the classroom? It is precisely those characteristics of CLT listed above that may, in part, be responsible for this shortcoming (12).

On the basis of this experience of immersion and acquisition "a strong claim has been made that focus on form may be necessary to push learners beyond communicatively effective language toward target-like second language ability" (Doughty \&Williams, 1998 p. 2). Focus on form according to Long (1991), is a component of task-based teaching which requires instructors to give little extra guidance to their students as they accomplish the task and attend to the 
grammatical form. Ortega (1999, p.11) pointed out that "focus on form is a range of pedagogical interventions that seek to attract and direct learners' attention to specific formal aspects of the language code in the context of meaningful language use." It is important to clarify that focus on form is not a return to the old way of making grammar practice a central focus of the class Williams (1995), focus on form rather entails a prerequisite engagement in meaning before attention to linguistic feature that can be expected to be effective (Doughty \&Williams, $1998 \mathrm{p}$. 3). Long (1991) established the difference between focus on forms that represents the traditional language teaching focused in grammar, and focus on form, that represents the teaching of linguistic form involved in communication.

There are some studies that support the independent variable ICS task as a task focus on form that has an effect in accuracy during oral production. In a pilot study Salaberry and LopezOrtega (1998) demonstrated with 74 college students enrolled in intermediate Spanish courses, that attention to form is a good predictor of accuracy among L2 learners with at least some grammatical structures, especially in narrative. Lindseth (2016) in a study examined the effects of form-focused instruction (FFI) on the acquisition of subject-verb inversion word order in declarative sentences in German during spontaneous speech. The participants of the study were 13 students registered in a semester-long abroad program in Germany and the students had a least third semester college level instruction in German. All 13 participant attended classes for 15 hours per week and were enrolled in the same courses. All students had in this program 1 hour of grammatical consultation during which they receive instruction in case of questions about structure or vocabulary. The study had one experimental and one control group and the same instructor taught both groups. The experimental groups received a planned grammatical consultation hour on subject-verb inversion and the control group followed the regular 
instruction in the grammatical consultation. The data revealed that the experimental group, which received an intensive planned FFI, had a statistical significance in accuracy of the use of inversion structure.

In summary, Communicative Language Teaching has greatly impacted the field of second or foreign language instruction, radically changing the language classroom and producing students who have been more successful than their predecessors who received instruction in grammar alone (Williams, 1995, p. 12). According to Wang and Castro (2010), both input and output are integral to Communicative Language Teaching in a foreign language context, such as the one in this study. The focus of this investigation is the ICS task (see table 4 in page 26), which is primarily concerned with output, particularly oral proficiency in terms of accuracy. The research cited in this section demonstrates the importance of focus on form tasks in improving students' accuracy in output. The following section examines such tasks.

\section{Developing Accuracy in the Target Language through Task-Based Oral Production}

Accuracy in language learner output is one of the main foci of this study; therefore, it is important to clarify this term. Accuracy is linked to "the ability to express a particular meaning via a particular form or structure" (Lee \& VanPatten, 2003, p.169). Skehan (1998b), as cited by Ellis (2005), defines accuracy as "the ability of the learner to perform in accordance with target language norms," and Skehan also states that accuracy "reflects the learner's attempt to control existing resources and to avoid errors" (p.15). The goal of this investigation is to measure the effects on L2 accuracy of "task-based oral production," specifically the ICS task. Therefore, the ICS task is the independent variable, while accuracy in oral production is the dependent variable. 
The design of the ICS task draws upon research from various approaches to second language pedagogy.

One of these approaches is the Cognition Hypothesis (Robinson, 2001), which claims that "pedagogic tasks" should be designed and sequenced for learners on the basis of increasing cognitive complexity. According to Robinson and Gilabert (2007), tasks that place greater cognitive demands on the learner lead to greater accuracy and complexity in output due to the heightened "functional and conceptual communicative demands" of the situation (p. 162). Therefore, Robinson (2001) proposes the Triadic Componential Framework for pedagogic L2 tasks to delineate components of Task Complexity, Task Conditions and task Difficulty in two dimensions: resource directing and resource dispersing. Task complexity involves cognitive factors, for example, reasoning as resource directing factor and planning task as resource dispersing. Task Condition, which involves interactive factors, for example, few participants as resource directing and same proficiency as resource dispersing; and Task Difficulty, involves learner (ability) factors, for example, working memory as resource directing and aptitude, anxiety and openness, as resource dispersing. There are some similar statements that support the Cognition Hypothesis. For example Kormos (2006) established a relation between speech production and the Cognition Hypothesis and pointed out that "sequenced task on cognitive complexity allows students be able to progress from simple linguistic task performed in a classroom to complex communicative task that students will face in real life settings" (p.53). Kormos pointed out that cognitively complex tasks 'might direct learner' $\mathrm{s}$ attention to noticing the gap in their existing knowledge and might create motivation to acquire the structure that would have been needed to successfully complete the task" (p.54). Later, Mavrou (2013) claimed that the Cognition Hypothesis predicts that the greater the exigencies of the task, the more 
language learners will be encouraged to draw upon more complex linguistic resources, resulting in language production that is more accurate and complex. Table 5 summarizes the relevant aspects of Cognition Hypothesis:

Table 5

The Cognition Hypothesis (Robinson \& Gilabert, 2007)

\begin{tabular}{|c|c|c|c|c|}
\hline \multirow{3}{*}{$\begin{array}{l}\text { Triadic } \\
\text { Componential } \\
\text { of the task }\end{array}$} & $\begin{array}{r}\text { Task } \\
\text { Complexity }\end{array}$ & $\Rightarrow$ & $\begin{array}{l}\text { Cognitive demand } \\
\text { +direct and - disperse } \\
\text { resources }\end{array}$ & $=$ Accuracy/complexity \\
\hline & $\begin{array}{r}\text { Task } \\
\text { Condition }\end{array}$ & $\Rightarrow$ & $\begin{array}{l}\text { Interaction +direct } \\
\text { interaction and - } \\
\text { disperse interaction } \\
\text { resources }\end{array}$ & $=$ Accuracy/complexity \\
\hline & $\begin{array}{l}\text { Task } \\
\text { Difficulty }\end{array}$ & & $\begin{array}{l}\text { Learners factor } \\
\text { ability+direct ability } \\
\text { learner factors and - } \\
\text { disperse ability } \\
\text { learners factors } \\
\text { resources }\end{array}$ & $=$ Accuracy/complexity \\
\hline
\end{tabular}

Note. Cognitive Complexity (Robinson \& Gilabert, 2007).

In an effort to support the Cognition Hypothesis, Gilabert conducted a study on the effect of task complexity on "self-repair behavior" (Robinson \& Gilabert, 2007, p. 173). The participants in this study (42 Spanish L1 learners of English) were grouped by proficiency, resulting in two groups: the high proficiency group and the low proficiency group. Both groups were asked to complete three task types, narrative task, instruction giving task, and decisionmaking task, each at two different levels of complexity. The narrative task, consisted of telling 
one story in the "here and now" and another in the "there and then" (presumably the more cognitively demanding task). For the instruction-giving task, learners were required to complete a "map task," that is, to provide directions along three different axes to increase the complexity of the task. For the decision-making task, the cognitive load was heightened by increasing the complexity of the task through interconnectedness of the events involved. Gilabert hypothesized that "increased task complexity would result in a larger frequency and amount of self-repairs" (p.173). The results of the statistical analysis showed a positive correlation between task complexity and self-repair behavior, especially when performing the narrative task (achieving a greater accuracy), less accuracy was revealed in the giving instruction task and decision-making task.

The Trade-off Hypothesis (Skehan, 2009) also supports the task design employed in the present study, despite Skehan's opposition to the Cognition Hypothesis. He maintains that attending especially to one or two of the factors of CAF (complexity, accuracy, and fluency) reduces the amount of working memory available to support the others and that simultaneously attending to all three is rare (Skehan, 2009).

The Trade-off Hypothesis posits that facilitating the improvement of both accuracy and complexity does not depend on the cognitive demand of the task, as claimed by the Cognition Hypothesis, rather it is a result of a number of variables regarding the task and its conditions (Skehan, 2009). Skehan 2001, as cited by Skehan 2009 (p.511-512) offers some research-based generalizations regarding various task factors and their effects on student performance such as:

1) tasks based on concrete or familiar information advantage accuracy and fluency;

2) tasks containing clear structure advantage accuracy and fluency; 
3) interactive tasks advantage accuracy and complexity;

4) tasks requiring information manipulation lead to higher complexity; and

5) post-tasks condition such as public performance or transcription of one's own performance raise accuracy.

Skehan (2009) discussed various studies that support the Trade-off Hypothesis and joint accuracy and complexity results during oral performance. The first of these studies investigated different types of planning: solitary, group based, or teacher led. The results revealed that teacher-led planning improved both complexity and accuracy, unlike the other planning conditions. A second study analyzed by Skehan was Ellis's (2005) study, which distinguished planning with complexification (online, or impromptu planning) and planning with rehearsal. The result was that planning with complexification was correlated with greater complexity and planning with rehearsal "was associated with increases in accuracy" (Skehan, 2009,521). Thus, supporting the idea that "complexity, accuracy and fluency enter into competition with one another given the limited attentional capacity of second language users" (Skehan and Foster, 1997, p.185).

Another task-type study, carried out by Skehan and Foster (1997) and conducted with 40 EFL college students, consisted of the effect of planning tasks and post-tasks with different conditions to measure complexity, accuracy, and fluency. The participants were members of four different classes; two classes were assigned to the "planning" condition (i.e., they were given ten minutes of planning time), and two were assigned to the "non-planning" condition. Within each of these groups, pairs were randomly selected for the "post-task" or to the "non-post-task" condition. The post-task entailed repeating their presentation in front of the whole class. The tasks were a personal task (describing to a partner what was surprising about life in Britain), a 
narrative task (telling a story to a partner based on a cartoon strip) and a decision-making (giving advice to hypothetical people and defending the suggestions). The result in terms of accuracy showed that in the post-task condition L2 learners improved because they paid attention to their language, as they knew they would have to submit to subsequent public scrutiny. In addition, planning led to greater accuracy for the personal information exchange and narrative tasks. The decision-making task showed a greater effect on complexity and less effect in accuracy.

Skehan (2014) has taken up the subject of planning again much more recently to summarize the current ideas regarding the positive and negative influences of planning in second language performance. Skehan, at the time of planning a task, links accuracy (one of the independent variables in this study) to repetition of the task, structure of the task and processing of the task. Repetition according to Skehan has a strong effect in accuracy because "the first performance enables ideas and language to be made more salient and trigger deep lemma activation which is still available for subsequent performance" (p.243). Structure of the task, raises accuracy (for example a "there and then" activity) because it clarifies the conceptualizer (what the speaker wants to say) and then the formulation (lexicon and syntax) of the speech.

In a previous study, Ellis (1987) investigated the effect of planning on L2 production. The focus of this research was the effect of the time allotted for pre-task planning and "coplanning" on learners' accuracy while completing a narrative task. Ellis hypothesized that increased planning time would lead to greater morphological accuracy. The 17 ESL learners who participated in the study were given a storytelling task. They were instructed to use the past tense form in each narrative and to begin with the phrase "One day..." In the first task, participants were provided with a set of six pictures to use as a prompt to write a story within the one-hour time limit. After writing the narratives, they started with the second task, which was to retell 
their written narratives out loud twice. Data were only collected from the second telling of the story. For the third task, participants were granted only two minutes to prepare a second oral narrative based on a different set of pictures. The results demonstrated a consistent positive correlation between one-hour planning time and accuracy since the planning provides more time to the L2 learner to devote attention to the form.

Table 6

Study (Skehan \& Foster 1997) Task Type pre-planning and Post Task

Task \begin{tabular}{ll}
\hline Planning Task & $\Rightarrow$ raised accuracy \\
Narrative Task & $\Rightarrow$ raised accuracy
\end{tabular}

Decision Making Task

Post- Task $\left\{\begin{array}{l}\text { Personal Task } \quad \Rightarrow \quad \text { raised accuracy } \\ \text { Narrative Task } \quad \Rightarrow \quad \text { raised accuracy } \\ \text { Decision Making Task }\end{array}\right.$

Note. The planning with time condition, and post-task with public presentation condition push language learners to greater accuracy (Skehan \& Foster,1997). 
Later, Ellis (2009) showed the effect of various types of task planning: pre-task planning and within-task planning on the fluency, complexity and accuracy of L2 oral performance (see Table 7). Pre-task planning is done before L2 students perform the task and can be rehearsal or strategic planning. Pre-task rehearsal is when the L2 students have the opportunity to perform the task two or more times, and strategic pre-task planning is when L2 students plan what content to express and what language to use, but without the opportunity to perform the task beforehand. Within-task planning occurs while learners are actually performing a task; students may feel pressured if they have to perform the task with limited time, and that pressure can be relieved when students have an unlimited amount of time to perform the task (Ellis 2009). Although learners' fluency seems to improve with any type of planning, the effect of planning on accuracy and complexity is less straightforward depending on a variety of factors, including the type of planning as well as learner-related factors. Ellis, in a meta-analysis in nineteen studies, investigated the effect of rehearsal and strategic planning on L2 fluency, complexity and accuracy under different conditions. The results related to accuracy in three studies revealed that rehearsal has a beneficial effect on learners' subsequent performance of the same task. Thirteen of the studies found that planning enhances accuracy, but six found no effect. One factor that does appear to influence the result for accuracy is learner's proficiency when planning; thus, it was found that planning has much less effect with advanced level learners than with learners of low proficiency. Regarding the guided-planning condition, the research suggests that guided planning can have an effect on accuracy. Just as Skehan (2014) concluded, the result of this meta-analysis demonstrated that a variety of planning factors including familiarity, pre-task planning, online planning, and structure processing give to the planning a wide range and 
different effects in CAF. Variables such as repetition, structure, processing, and post task condition have more notable effects in accuracy which is the concern of this study.

Table 7

Effect of Task Planning (Ellis, 2009)

Task

Note. Strategic Pre-planning, rehearsal and guide planning conditions are characteristics of the ICS task studied in this investigation.

Ortega (1999) also investigated the hypothesis that pre-task planning results in higher quality L2 production. Sixty-four native English speakers in advanced Spanish as a Foreign Language classes participated in this study. They were randomly arranged in four experimental groups with eight dyads each. Each member of the dyad was randomly selected to be the listener or the speaker. The speaker was given two comparable storytelling tasks under two different conditions: one with minimal pre-task planning and the other with ten minutes of pre-task planning time. Under both conditions, the speaker was given an eight-picture story strip and listened to an L1 recording of the story to ensure rather uniform narratives and to lighten the cognitive load. However, in the planning condition, the speaker was also given 10 minutes to 
prepare his or her narration. The speakers were permitted to take notes but they were not permitted to read from the notes while telling the story. Listeners were required to complete a number of written tasks during and after the narration. Finally, the speaker participated in a retrospective interview regarding his or her planning process. Ortega found that planned speech was more accurate than unplanned speech. Planned speech was also more fluent and complex than unplanned speech. Finally planned speech and unplanned speech did not differ significantly in lexical ranges.

\section{ICS Task Design According to the Research}

In order to categorize the ICS task as task-based oral production that increases student accuracy, elements of task design proposed by the Cognition Hypothesis (Robinson \& Gilabert, 2007), The Trade-off Hypothesis (Skehan, 2009), and the results of Ellis's (1987, 2009) and Ortega's (1999) investigations discussed above were employed.

Regarding the Cognition Hypothesis, it can be said that, despite the presence of "resource dispersing variables" (such as the provision of planning time and instruction), which moderate the cognitive character of the ICS task, this task could be considered a "cognitively demanding" task because the cultural context to investigate might be totally or partially unfamiliar to L2 students, can be situated in past or present time, may include interconnected events, and the language learner has to use reasoning, attention, and memory to complete the task.

In addition to the consideration given to the Cognition Hypothesis reflected in the cognitive demands placed on the student in the task at hand, the design of the ICS task is such that it also incorporates insights from the Trade-off Hypothesis. In order to direct students' attentional resources towards accuracy, the ICS task is a pre-planning task with a post-task. The 
students have time to investigate and prepare the task beforehand, and they are then required to present the task orally to the class.

The ICS task is related to the tasks studied by Ellis (2009) in that it incorporates elements of strategic pre-planning and rehearsal because the L2 student plans the content and the language to use with instructor guidance and has opportunity to rehearse before completing the task. Finally, Ortega's (1999) research about "planned speech" and its effects on accuracy provides further evidence to support the design of the ICS task. Nevertheless, there is still no definitive answer regarding the extent of the effect of the type of task employed and planning on language learners' accuracy in oral production (Ellis, 2009, p. 497). Skehan (2014) echoed this sentiment regarding planning, stating that "we have to wait and see what future research tell us about the sort of fine-grained relationships with different aspects of performance that these new concepts might reveal"'(p. 213).

It is the intention of this study to contribute to this body of research, providing some conclusions about the effect of a task on accuracy. Therefore, based on the foundation of the research cited in the previous section, the ICS task includes elements of instructor guidance, preplanning (with optional extra interaction with the instructor or other students), cognitively demanding elements, and the required public presentation of the completed task. Participants' accuracy in their individual performance in the final poster project, after having carried out both ICS tasks, was evaluated to measure the effect of the ICS task on their accuracy in oral production.

It is the purpose of the author not only to demonstrate the efficacy of the ICS task in improving students' accuracy (as well as their cultural content knowledge), but also to illustrate 
its place in the modern language syllabus. Therefore, the following section briefly examines the history of foreign and second language syllabus design and locates the ICS task within current ideologies in this field.

\section{Syllabus Design and Task-Based Oral Production}

Richards (2003) stated that a syllabus "is a specification of the content of a course of instruction and lists what will be taught and tested" (p. 2). Syllabus planning takes into account the preparer's perspective of and familiarity with the content area (or areas), related theories and research, and the current trends in SLA as well as his or her own experiences (Richards, 2003).

It is pertinent to explain that in the language curriculum development field, the language syllabus has progressed from a grammatical language syllabus to a communicative language syllabus, which involves the term 'task-based oral production,' used in this study to define the ICS task. Modern approaches to curriculum development began around the 1960s after other approaches had experimented with a variety of syllabus designs. Language curriculum development refers to the field of applied linguistics, and it describes and interrelates a "set of processes that focuses on designing, revising, implementing, and evaluating language programs" (Richards, 2003, p. 2).

Richards (2003) explained that many approaches have been followed to create a language syllabus framework. The structural syllabi that prevailed at the beginning of the 20th century were replaced by the communicative syllabus in the 1970s because of the need for developing communicative competence rather than the rote learning of linguistic structures. Since that time, the field of SLA has been quite critical of grammatical syllabi for a number of reasons, including that they reflect only a part of language use, they create a very artificial context for language 
acquisition, they generally present only isolated phrases or sentences and do not address discourse, they elevate form above meaning, and they deemphasize communicative skills (Richards, 2003).

Communicative syllabi, on the other hand, tend to be organized around a functional, situational, task-based, content-based, and/or skill-based framework rather than a structural one. The syllabus designs most pertinent to this study are the task-based syllabus and skill-based syllabus. A task-based syllabus is organized around tasks that students have to complete in the target language such as finding solutions for a puzzle, giving directions, etc. These tasks involve cognitive and communicative processes. However, a skill-based syllabus groups the linguistic competencies together (vocabulary, grammar, pronunciation) in unspecific settings, so that students develop the abilities for reading, writing, and speaking (Reilly, 1988; Richards, 2003). In this study, a "skill-based syllabus" is the structure that supports the ICS task - the skill represented is oral production.

The ICS task is not only designed to improve students' communicative competence, but also to increase their knowledge of the target culture. The last section of this literature review is related to cultural content knowledge, one of the dependent variables investigated. It starts by presenting the importance of culture and a definition of the term and then the approaches to culture from a language teaching/learning point of view.

\section{Definition of Culture and Cultural Approaches in Foreign Language Teaching/Learning}

All forms of communication necessitate a certain level of socio-cultural understanding and competence "to produce and negotiate, to understand and interpret, and to create and present appropriate and meaningful communication" (National Standards ACTFL, 2006 p.15). Thanks to 
the field of ethnography, it has been shown that a number of different speech events are tied to specific culturally dictated structures that may vary from one group to the next; language learners must be aware of these structures in order to communicate appropriately in those situations in the target culture. Everything from daily interactions in shops or on the phone, to much more specialized speech acts use culture-specific variations (Schulz, 2007).

Kramsch (2014) pointed out when language "is used in context of communication, it is bound up with culture in multiple and complex ways" (p.3). Kramsch also stated, "The way in which people use the spoken, written, or visual medium itself creates meanings that are understandable to the group they belong to, for example, through a speaker's tone of voice, accent, conversational style, gesture and facial expressions" (p.3), and speakers perceive the limitation of using cultural values as a rejection of their social group.

According to (Kramsch, 1995) from a humanistic point of view, culture focuses on the way a social group represents itself through art, literature, and social institutions. From a social sciences point of view, it refers to ideals, values, beliefs, and ways of thinking. Both definitions have created different approaches to the study of culture: the historical approach and the ethnographic approach. The historical approach is based on the written tradition of the texts: "It understands the present and imagines the future in the light of the past" (p.2). The ethnographic approach is based on observation, data collection, and analysis of phenomena in the natural setting, and "it understands the present by viewing current events: it derives its authority from the discovery of laws that regulate social life" (p.2).

Phillips (2015) stated at the ACTFL pre-conference workshop, that when foreign languages instructors create resources with cultural content by using the Ps framework students' 
knowledge and understanding improve. Figure 2 shows the three Ps framework that summarizes the concept of culture in foreign language education.

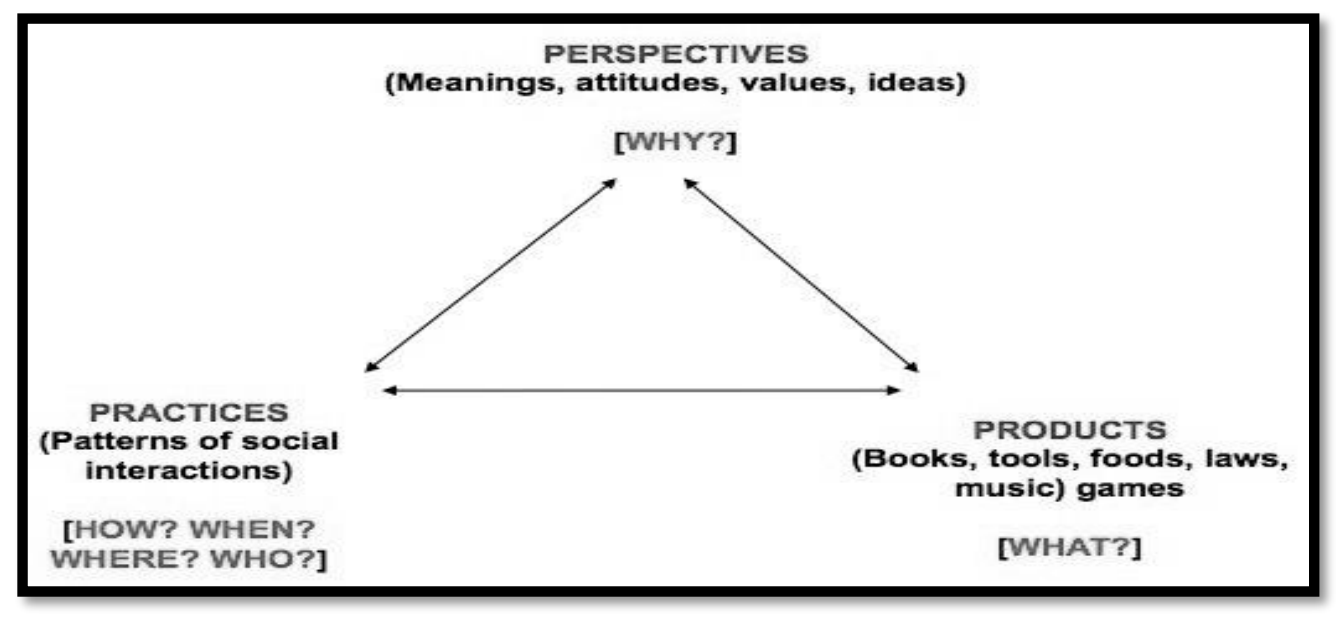

Figure 2. Definition of Culture according to National Standards (1999). Source: Allen (2013) ACTL Pre-convention Workshop.

Practices are defined as the patterns of behavior that are accepted by a society.

Products are what society creates, both tangible (e.g. artworks and music) and intangible (e.g. rituals and traditions). Finally, perspectives are the underlying ideas, attitudes, meanings, and values that explain why a society performs its practices and creates its products (National Standards ACTFL, 1996).

The inquiry about culture topics that L2 students have to do to accomplish with the ICS task, has a relationship with Allen (2013) that pointed out, in foreign language teaching the culture competence is earned for L2 students when they learn to see relationships/links between products, practices, and perspectives through strategies applied in the classroom.

On the other hand, Nieto (2010) pointed out that the first steps to integrate culture into the teaching of foreign languages have been the presentation of diverse situations such as 
holidays and shopping places, which were created according to the communication needs of the learners. Even though these situations are elements of culture, it is not enough.

Hall (1976) developed the iceberg analogy of culture. Hall reasoned that the external or visible part of the iceberg is the conscious behaviors (see Figure 3).

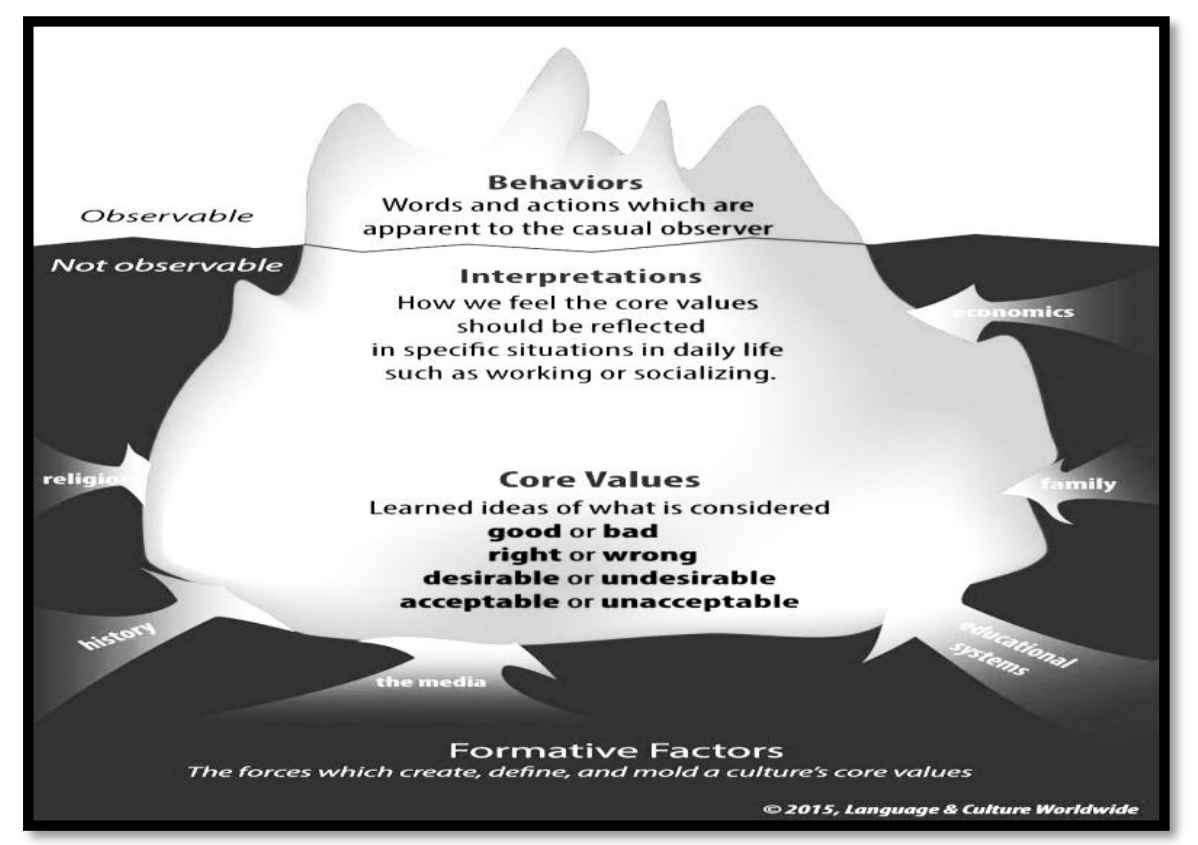

Figure 3. The Iceberg concept of cultural competency involves moving up and down, linking the visible phenomena to invisible values (Allen, 2013).

In the Iceberg concept of culture, elements of the culture like clothing, music, language, gestures, food, rituals, etc., are the tip or visible part of the iceberg. This visible part has its foundation in a larger invisible part underneath the waterline related to the core values. The behavior of different cultures may appear less foreign and less threatening with an understanding of the core values. In other words, only a smaller proportion of cultural aspects is more visible and more obvious than other aspects that are just as essential to our understanding of how cultures work (Penstone, 2011). 
Schulz (2007) proposes five fundamental objectives for cultural learning in the foreign language classroom that involve not only the insights presented before, but also cultural aspects that L2 learners face when completing the ICS task:

1. Students become aware of the impact that history, the economy, geography, society, politics, and religion can have on cultural perspectives, products and practices and can show their awareness in a measurable way.

2. Students grow in their ability to perceive how sociolinguistic and situational factors affect both verbal and nonverbal communication.

3. Students not only identify stereotypes and generalizations about their native culture and the target culture, but also evaluate these ideas with supporting evidence.

4. Students understand that each culture/language has its own "images, words, phrases, proverbs, idiomatic formulations, gestures, etc.” (p. 17) and can demonstrate that knowledge.

5. Students are able to identify the causes of misunderstandings in intercultural communication.

The next chapter III presents the timeline and the design of this study, population, participants, selection of the groups, the characteristics and procedure of the ICS task that is the independent variable, and the instrument that measured the independent variables accuracy and cultural content knowledge. 


\section{Chapter III}

\section{Methodology}

This chapter presents the methodology for this study, which consisted of the application of the independent variable (the ICS task) on two dependent variables (accuracy and cultural content knowledge of intermediate 204 Spanish students). The independent variable has an experimental level and a control level.

First the population, participants, sample, and the random selection of the experimental and control groups are described, followed by the procedure of the ICS task, design, and instruments. Finally, the results of one-way ANOVA that was used to measure the effect of the independent variable (ICS task) on the dependent variables (accuracy and cultural content knowledge) are presented.

\section{The Population}

The population for this study was all L2 students registered for Intermediate Spanish 204 in the Spring semester of 2014 in the American university chosen for this study. It is important to say that a requirement for Spanish 204 students is to have previously passed the beginning 101, 102 and intermediate 203 Spanish courses. Those students who for any reasons present doubt about their level of proficiency, must take a placement test which is based on the Oral Proficiency Test (OPI) of the ACTFL. There were 350 students registered in the Spanish 204 courses for Spring 2014. These students were registered in 14 sections offered at various times between 8:30 a.m. and 8:15 p.m., from Monday through Friday. There were seven instructors, and every instructor had two sections (see Appendix D). 
It is important to clarify that the sections given on Tuesday and Thursday were 75 minutes in duration, therefore, these courses did not participate in this investigation in order to keep the same time (50 minutes) for all classes. Thus, the 94 students registered in the four sections on Tuesday and Thursday, were excluded from this study. For that reason, a total of 256 students registered in 10 sections scheduled on Mondays/Wednesdays /Fridays between 8:30 a.m. and 3:20 p.m. were available for this study (see the outline in appendix D that summarized the characteristics of all the sections involved in this study).

\section{Participants}

The sample consisted of 57 students. After the instructors explained the study to the class and gave students the Consent Information and HIPAA Form, 57 students agreed to participate in this study. During the data analysis phase of this study, three students ( 2 controls and 1 experimental) were eliminated from this study because their video recorded speeches were incomprehensible or very dark.

The students who participated in this investigation were from three different instructors sections: A, L, and S. Instructor A got 37 students to participate in the investigation (12 students for the experimental group and 25 students for the control group). Instructor L got 16 students to participate in the investigation (1 student for the experimental group and 15 students for the control group). Instructor S got 4 students to participate in the investigation (1 student for the experimental group and 3 students for the control group).

\section{Random Selection of the Experimental and Control Groups}

The random selection for the experimental and control groups (sections) was done by using the Research Randomizer Program free web page www.randomizer.org. One experimental 
and one control section for each graduate teaching assistant (GTA) was involved in the study on Mondays, Wednesdays, and Fridays.

Before using the randomizer, the investigator assigned a zero (0) for the control group and one (1) for the experimental group. Then the first number to appear from the randomizer was used for the first section that the instructors were teaching, and the other number was used for the second sections that the instructors were teaching. Once entered into the randomizer program the investigator used on set, two numbers, a range from 0 to 1 and clicked the link "randomize now". The results were as the following table indicates:

Table 8

Selection of the Groups

Instructor/GTAs Spanish 204 Spring $2014 \quad$ First Course taught

Second course taught

\begin{tabular}{llll}
\hline A & 0 & 1 \\
L & 1 & 0 \\
S & 0 & 1 \\
\hline
\end{tabular}

Note: Random selection of experimental and control courses taught by the instructor that participate in this study. In this table, $0=$ control course and $1=$ experimental course.

Table 8 explains that for instructor " $\mathrm{A}$ " the experimental course was the second course taught where 12 of the students in the class agreed to participate in the study, and the control group was the first course taught where 25 of the students in the class agreed to participate in this study. For instructor " $L$ " the experimental course was the first course taught where 1 student agreed to participate in this study and, the control course was the second course taught where 15 
students accepted to participate in this study. For instructor "S" the experimental course was the second course taught where 1 student agreed to participate in this study, and the control course was the first course taught where 3 students agreed to participate in this study. As mentioned before, all three instructors taught both courses on Mondays, Wednesdays, and Fridays.

\section{Procedure}

The study lasted six weeks, beginning the third week in March 2014 and ending the last week in April 2014, when students presented the poster project (see Table 9). A meeting with the basic Spanish program coordinator and graduate teaching assistants (GTAs) in Spanish 204 was held before the investigation started. The investigator gave instructions to the GTAs about how and when the tasks had to be applied, to ensure that each GTA had the same preparation to complete the task in the classroom (Appendix F outlines the calendar given to GTAs to accomplish the ICS task)._Monday, Wednesday, and Friday were the days for the application and supervision of the ICS task. Tuesday and Thursday were the days to give support to the students/instructors about the ICS task, and also to give the instructors the questionnaire about cultural content knowledge of their instruction, related to the third research question.

The questionnaire answered by the instructors added a qualitative piece to this study. This questionnaire helps the investigator determine whether the cultural content that instructors include in their instruction has an effect on the cultural content knowledge of L2 students. The investigator used this information to answer the third research question by analyzing not only if there are similarities or differences on the teaching of culture during class time, but also if the cultural background of the GTAs affects the teaching of culture (Appendix G presents the 7 questions posed to the GTAs). 


\section{The Task}

Stoller's (2002) concept of project work supports the design of the ICS task. She claimed that a project work can culminates in an oral production where students process information of varied sources, students can work in groups or on their own, and the product can be shared with others. Project work provides the students with opportunities to focus not only on fluency but also on accuracy at different projects-work stages. The procedure of the ICS task is supported by previous studies mentioned in the literature review related to the Cognition Hypothesis of Robinson \& Gilabert (2007), the Trade-Off Hypothesis of Foster, Skehan (1997, 2014); Ellis (2009); and Ortega (2009). It is also supported by the implications of a research completed by Gharbabi and Mousavi (2012) who found that there is a direct "relationship between the employment of language learning strategies and learners' levels of language proficiency" (p.111). Therefore, teachers should be trained to teach strategies to language learners. Oxford and Burry-stock (1995) as cited by Gharbabi and Mousavi (2012,p.112) proposed the following strategy for L2 learners: 1) memory strategy (e.g. imagery) 2) cognitive strategies (e.g. reasoning) 3) Compensation strategies (e.g. gesture to convey meaning) 4) metacognitive strategies (e.g. monitoring error) 5) affective strategies (e.g. self-encouragement) and 6) Social strategies (e.g. becoming culturally aware).

Language teacher also should design the language by using the proficiency level. Omaggio (2001) suggested five hypotheses about a proficiency-oriented classroom. Three of Omaggio's hypotheses are related to the foundation of the ICS task. The first hypothesis refers to the opportunities that must be provided for students to practice using languages in a range of contexts to be encountered in the target language and culture. The second hypothesis states that there should be a concern for developing accuracy from the beginning of instruction. Finally, the 
third Omaggio's hypothesis posits that the cultural understanding must be promoted in various ways, so that students are prepared to deal more harmoniously in the target language community.

The ICS task was applied during five weeks. The instructor encouraged students in the experimental group to investigate about any cultural topics addressed in chapters 12 to 15 of the textbook, and each student individually prepared an oral presentation. Once the students selected their topics, the instructor and students scheduled the presentation of the ICS task using a format to record the topics and dates of both oral presentations (see Appendix E). The procedure for presenting the ICS task was explained to students in a format before the planning time. The time for planning ICS tasks was between 5-7 days. During the task planning time, a meeting between students and instructors took place to give feedback to students when preparing the topic. It was suggested that the students ask the instructor any questions related to the topic of the presentation, Spanish grammar, or vocabulary to be used. Students supplemented the presentation with Power Point slides, posters, pictures etc., and prepared individual cultural presentations of no fewer than five sentences. Since the main purpose of this investigation was to measure accuracy of students' oral production, they were not permitted to read notes during the presentations (see the format in Appendix C). Sentences read by students were not counted. The allotted time limit per presentation was 5 to 7 minutes so that the ICS task did not interfere with the lesson of that day. During the presentations of the ICS task the teacher would not interrupt the students. However after the presentation, the instructor formulated open-ended questions so that the rest of the class who was not participating in the study could benefit from the activity. This part is linked to the role of the instructor proposed by Skehan (2014) from a pedagogic point of view of second language acquisition, "it is assumed that the teacher will not be intrusive, but will nonetheless be very alert and in some way paying attention to the language" p.247), and 
the instructor has to link different stages of the task (pre-task, during task and post-task), so that the task can be used more effectively. Table 9 summarizes the timeline of study.

Table 9

Timeline for the Study

\begin{tabular}{ll}
\hline Week 1 & $\begin{array}{l}\text { Before the investigation started, a meeting with the basic Spanish program } \\
\text { March 17, 2014 }\end{array}$ \\
& $\begin{array}{l}\text { coordinator and graduate teaching assistants (GTAs) in Spanish 204 was held. } \\
\text { The investigator gave instructions to the GTAs about how and when the tasks } \\
\text { had to be applied. }\end{array}$ \\
\hline Week 2 & $\begin{array}{l}\text { The instructor encouraged students of the experimental group to investigate } \\
\text { the topics established in Chapters } 12 \text { to } 15 \text { of the textbook. }\end{array}$ \\
\hline Week 3 & ICS Task Presentation. \\
\hline Week 4 & ICS Task Presentation. \\
\hline Week 5 & ICS Task Presentation. \\
April 25, 2014 & $\begin{array}{l}\text { ICS Task Presentaton. } \\
\text { Poster Project Presentation. }\end{array}$
\end{tabular}

The control group followed the regular program that consists of a presentation to the class of a poster project that must be put together over the course of the second half of the semester. This poster project was done by groups of students and presented orally to the rest of the class at the end of the semester (see Appendix A). In the textbook (Amores et al; 2011) used by Spanish courses that participated in this study, every chapter presented rich cultural content such as Entrada cultural, Expresiones artísticas, Nota cultural, Nota interdisciplinaria, Lectura cultural, Concurso de videoblogs, Conexiones culturales, and Conexiones culturales en vivo. These readings, videos, notes, and fine art presentations offered students extensive cultural perspectives and promoted cross-cultural comparison and connections. It also facilitated students and instructors their cooperation in this investigation. (See examples in Appendices B and B1F 
Students from both the experimental and control groups presented the poster project at the end of the semester, as the program requires. During the poster project presentation, students from the experimental and control groups were video recorded so that the investigator could measure and compare the accuracy between students who did the ICS task and the students who followed the regular schedule.

\section{Research Design}

This study is an experimental study because the levels of the independent variable were imposed to determine their effect on the dependent variables. The study has two dependent variables: cultural content knowledge and accuracy; and one independent variable: the ICS task. There are two groups: a control group and an experimental group. A post-test was applied to both groups. In the case of the dependent variable accuracy, the post-test was the poster project, and in the case of cultural content knowledge, the post-test was the final exam (see Tables 10 and 11).

Table 10

Design for the Experimental Study of Accuracy

\begin{tabular}{ccccc}
\hline \multicolumn{1}{c}{ Group } & Assigned & \# Students & Treatment & Post-test \\
\hline 3 Experimental & Random & 14 & ICS task & Poster Project \\
3 Control & Random & 43 & No ICS task & Poster Project \\
\hline
\end{tabular}


Table 11

Design for the Experimental Study of Cultural Content Knowledge

\begin{tabular}{ccccc}
\hline \multicolumn{1}{c}{ Group } & Assigned & \# Students & Treatment & Post-test \\
\hline 3 Experimental & Random & 14 & ICS task & Cult. Cont. Knowl. \\
& & & & Final Exam \\
3 Control & Random & 43 & No ICS task & $\begin{array}{c}\text { Cult. Cont. Knowl. } \\
\end{array}$ \\
& & & & Final Exam \\
\hline
\end{tabular}

\section{Instruments to Measure Accuracy}

According to Skehan and Foster (1999) and Rahimpor and Hazar (2006) measuring errorfree clauses is a global and sensitive instrument for measuring global accuracy. Thus, in this investigation the data were videotaped, transcribed, and measured by calculating the number of error-free clauses out of the total number of clauses. For specific accuracy, grammatical items, such as article and verb use were measured. Articles were measured based on gender and number agreement and omission and verbs were measured based on their conjugation form. These instruments to measure the variable accuracy were applied in both the experimental and control groups during the poster project presentation. The validity of the instrument used in this study is based on its use in other investigations for example: the study of Rahimpour and Hazar (2006) that used a similar instrument to measure accuracy. The reliability of the instruments has been confirmed since has been replicated in various investigations about planning task for example the studies of Skehan and Foster, (1999); and Rahimpor and Hazar (2006).

Tables 12 and 13 show the instruments used in this investigation to measure global accuracy and specific accuracy of articles and verbs based on the instruments used in the aforementioned studies. 
Table 12

Global Accuracy Instrument

\begin{tabular}{|c|c|c|c|c|}
\hline Student & Total Clauses & $\begin{array}{l}\text { Clause with } \\
\text { Errors }\end{array}$ & $\begin{array}{l}\text { Error-Free } \\
\text { Clauses }\end{array}$ & $\begin{array}{l}\text { Error-Free clauses / } \\
\text { Total clauses }\end{array}$ \\
\hline \multicolumn{5}{|l|}{1} \\
\hline \multicolumn{5}{|l|}{2} \\
\hline 3 & & & & \\
\hline
\end{tabular}

Note: This instrument is modified from Skehan and Foster (1999) and Rahimpor and Hazar (2006).

Table 13

Specific Accuracy Instrument

\begin{tabular}{ccclcll}
\hline & & & & & Correct \\
Student & $\begin{array}{c}\text { Total of } \\
\text { Verbs }\end{array}$ & Verb & $\begin{array}{l}\text { Correct } \\
\text { Eerb/Total of } \\
\text { verbs }\end{array}$ & $\begin{array}{c}\text { Total } \\
\text { Article }\end{array}$ & $\begin{array}{l}\text { Article } \\
\text { Errors }\end{array}$ & $\begin{array}{l}\text { Article/Total } \\
\text { Articles }\end{array}$ \\
\hline 1 & & & & \\
\hline 2 & & & & \\
\hline 3 & & & & \\
\hline
\end{tabular}

Note: This instrument is modified from Salaberry and Lopez-Ortega (1998)

\section{Instrument to Measure Cultural Knowledge}

According to the syllabus, L2 students in intermediate Spanish 204 must take a final exam at the end of the semester. The final exam is regularly composed of five sections: listening, vocabulary, grammar, reading, and culture (see Appendix I). Every section of the exam has separate points. The questionnaire for the cultural section was the instrument that evaluated the 
cultural content in this study (see Table 15 ). The points assigned to the cultural part of the exam were considered the maximum points available, and the points earned for the experimental group and the control group were collected in the instrument as shown in Table 14.

Table 14

Cultural Content Knowledge Instrument

Student $\quad$ Points earned by Student/ Total of points assigned in the Cultural section of the Final Exam

\begin{tabular}{ll}
\hline 1 \\
\hline 2 \\
\hline 3 \\
\hline
\end{tabular}

Every Spanish student who participated in this study complete a consent form, the cultural section on the final exam (see Table 15 and Appendix I), a video recorded presentation and a script of the video from which the investigator got the data (see Appendixes J). 
Table 15

Questions from the Cultural Section of the Final Exam Translated into English

\section{The lifestyle of the Southern Cone}

\section{Choose ONE of the following topics and answer the questions:}

a) Herbs used as a medicine are popular all over the Hispanic world. One type of widely consumed herb in the Southern Cone is mate. This drink is also a staple of Argentine gauchos.

What other features are associated with the gaucho? Where does he live? What is his profession? Why is he an important figure?

b) Healthy eating is part of the Spanish and Latin American lifestyle. Organic agricultural products are increasingly popular. What advantages do these products have on the environment and health? Do you eat organic produce? Why?

c) Dancing is an essential part of the Hispanic lifestyle. The tango is a type of folk dance worldwide. Where did the tango originate? What does represent the tango in the Southern Cone? What instruments are used in tango?

(5 points: 2 content, 2 vocabulary, 1 grammar)

Note: The final exam administered in Spanish 204 in Spring 2014. The student was encouraged to answer one of the three questions presented and related to the life style of the "Cono Sur" completely in Spanish by using what they learned through the semester. Table 16 presents the questions in the original Spanish. 
Table 16

Questions from the Cultural Section of the Final Exam presented in Spanish in the final exam

\section{Cultura: el estilo de vida del Cono Sur.}

\section{Escoja UNO de los siguientes temas y conteste las preguntas.}

a) Las hierbas medicinales son populares en todo el mundo hispano. Un tipo de hierba en el Cono Sur es el mate. Esta bebida es también una característica de los gauchos argentinos. ¿Qué otras características van asociadas al gaucho? ¿Dónde vive? ¿Qué profesión tiene? ¿Por qué es una figura importante?

b) La alimentación saludable forma parte del estilo de vida español y latinoamericano. Los productos de la agricultura orgánica son cada vez más populares? ¿Qué ventajas tiene este tipo de productos para el medio ambiente y la salud? ¿Consume usted productos orgánicos? ¿Por qué?

c) Bailar es una parte esencial del estilo de vida hispano. El tango es un tipo de baile popular en todo el mundo. ¿Dónde se originó el tango? ¿Qué representa para el Cono Sur ? ¿Qué instrumentos se utilizan en el tango?

(5 puntos: 2 contenido, 2 vocabulario, 1 gramática) 


\section{Statistical Analyses}

After collecting the data for each dependent variable (accuracy and cultural content knowledge) in the instruments described above, the investigator proceeded to enter that data in the Statistical Program for Social Science (SPSS). Because this investigation has one independent variable with two levels (experimental and control) for each of the dependent variables, a one-way ANOVA was used to analyze the data statistically. The means of the two groups of participants (experimental and control) were compared in order to see how they varied for the single independent variable, which in this case was the ICS task (Cronk, 2008, p.65).

The data were collected using the instruments and were entered into SPSS as reflected in Table 17. The participants were identified using the following code: the letter (s) related to the name of the instructor, E/C related to the experimental /control group, and a number (1to 57) representing the student, used to preserve students' identities (see Table 17). The participants from the experimental group were entered into the SPSS program first, followed by the participants from the control group. After entering the data, a one-way ANOVA was run to analyze the data.

Note that in the analysis, the participants are treated as subjects, because the classes were randomly assigned for the treatments.

Table 17

Information Entered in the SPSS Statistical Program

\begin{tabular}{lllll}
\hline $\begin{array}{l}\text { Participants Codes } \\
\text { Total 57 }\end{array}$ & $\begin{array}{l}\text { Error Free Clauses } \\
\text { / \# of total 5 clauses }\end{array}$ & $\begin{array}{l}\text { \# Correct Verb Use } \\
\text { / \# of total verbs }\end{array}$ & $\begin{array}{l}\text { \# Correct Article } \\
\text { Use / \# of total } \\
\text { Articles }\end{array}$ & $\begin{array}{l}\text { Points earned in } \\
\text { Culture Section of } \\
\text { Final Exam / 5pts }\end{array}$ \\
\hline AGE1 & $2 / 4$ & $3 / 5$ & $1 / 1$ & 5 \\
\hline AGE2 & $1 / 3$ & $2 / 3$ & $1 / 3$ & 5 \\
\hline AGE3 & $4 / 5$ & $7 / 7$ & $5 / 6$ & 5 \\
\hline AGE4 & $4 / 5$ & $6 / 6$ & $5 / 6$ & 5 \\
\hline
\end{tabular}




\begin{tabular}{|c|c|c|c|c|}
\hline AGE5 & $4 / 5$ & $8 / 8$ & $7 / 8$ & 5 \\
\hline AGE6 & $4 / 5$ & $7 / 7$ & $8 / 9$ & 5 \\
\hline AGE7 & $4 / 5$ & $6 / 7$ & $8 / 8$ & 4 \\
\hline AGE8 & $5 / 5$ & $7 / 7$ & $11 / 11$ & 5 \\
\hline AGE9 & $2 / 4$ & $4 / 5$ & $3 / 4$ & 5 \\
\hline AGE10 & $1 / 2$ & $1 / 2$ & $2 / 2$ & 4 \\
\hline AGE11 & $3 / 3$ & $3 / 3$ & $1 / 1$ & 4 \\
\hline AGE12 & $4 / 5$ & $6 / 6$ & $5 / 7$ & 5 \\
\hline LE13 & $3 / 4$ & $4 / 5$ & $2 / 2$ & 5 \\
\hline SE 14 & 0 & 0 & 0 & 4.5 \\
\hline AGC15 & $3 / 5$ & $4 / 6$ & $3 / 4$ & 5 \\
\hline AGC16 & $4 / 5$ & $4 / 5$ & $5 / 5$ & 5 \\
\hline AGC17 & $2 / 2$ & $2 / 2$ & $2 / 2$ & 5 \\
\hline AGC18 & $4 / 5$ & $5 / 5$ & $10 / 11$ & 5 \\
\hline AGC19 & $2 / 3$ & $3 / 3$ & $0 / 1$ & 4 \\
\hline AGC20 & $3 / 5$ & $7 / 7$ & $8 / 10$ & 5 \\
\hline AGC21 & $2 / 3$ & $2 / 3$ & $2 / 2$ & 5 \\
\hline AGC22 & $3 / 5$ & $4 / 5$ & $11 / 12$ & 4 \\
\hline AGC23 & $4 / 5$ & $5 / 5$ & $6 / 7$ & 5 \\
\hline AGC24 & $4 / 5$ & $5 / 6$ & $5 / 5$ & 5 \\
\hline AGC25 & $2 / 3$ & $3 / 4$ & $6 / 6$ & 2 \\
\hline AGC26 & 0 & 0 & 0 & 5 \\
\hline AGC27 & $3 / 5$ & $7 / 7$ & $7 / 9$ & 5 \\
\hline AGC28 & $0 / 1$ & $1 / 1$ & $0 / 1$ & 5 \\
\hline AGC29 & $0 / 1$ & $1 / 1$ & $0 / 1$ & 4 \\
\hline AGC30 & 0 & 0 & 0 & 5 \\
\hline AGC31 & 0 & 0 & 0 & 0 \\
\hline AGC32 & $1 / 1$ & $1 / 1$ & $1 / 1$ & 4 \\
\hline AGC33 & $4 / 5$ & $6 / 6$ & $9 / 10$ & 5 \\
\hline AGC34 & 0 & 0 & 0 & 4 \\
\hline AGC35 & 0 & 0 & 0 & 3 \\
\hline AGC36 & $3 / 4$ & $3 / 4$ & $5 / 5$ & 5 \\
\hline AGC37 & 0 & 0 & 0 & 0 \\
\hline AGC38 & 0 & 0 & 0 & 5 \\
\hline AGC39 & 0 & 0 & 0 & 4 \\
\hline LC40 & $1 / 1$ & $1 / 1$ & $1 / 1$ & 5 \\
\hline LC41 & 0 & 0 & 0 & 0.5 \\
\hline LC42 & 0 & 0 & 0 & 2 \\
\hline LC43 & 0 & 0 & 0 & 2 \\
\hline LC44 & 0 & 0 & 0 & 2 \\
\hline LC45 & $4 / 5$ & $5 / 6$ & $7 / 7$ & 3 \\
\hline LC46 & $4 / 5$ & $6 / 7$ & $7 / 7$ & 3 \\
\hline LC47 & $2 / 2$ & $2 / 2$ & $2 / 2$ & 2.5 \\
\hline
\end{tabular}




\begin{tabular}{lllll}
\hline LC48 & $5 / 5$ & $6 / 6$ & $7 / 7$ & 5 \\
\hline LC49 & 0 & 0 & 0 & 3 \\
\hline LC50 & $1 / 1$ & $1 / 1$ & $2 / 2$ & 4.5 \\
\hline LC51 & 0 & 0 & 0 & 3.5 \\
\hline LC52 & 0 & 0 & 0 & 3 \\
\hline LC53 & $1 / 1$ & $2 / 2$ & $0 / 0$ & 4.5 \\
\hline LC54 & $5 / 5$ & $6 / 6$ & $5 / 5$ & 1 \\
\hline SC55 & $4 / 5$ & $4 / 5$ & $8 / 8$ & 4.5 \\
\hline SC56 & $5 / 5$ & $6 / 6$ & $7 / 7$ & 4.5 \\
\hline SC57 & $1 / 1$ & $1 / 1$ & $0 / 1$ & 4.5 \\
\hline
\end{tabular}

Note: Only the numerator of the fractions was entered into SPSS.

In the following chapter IV is presented the results obtained through SPSS with their respective analysis. 


\section{Chapter IV}

\section{Results and Discussions}

This chapter begins with a review of the data collection procedures and a description of the demographics of the subjects from whom the data was affected. The chapter then sets both the results by research questions along with discussion.

The Spanish instructors who participated in this study, and then were organized by the investigator provided the data. Demographic information is presented for those students enrolled in the Spanish 204 sections that participated in the investigation in Spring 2014 semester. Additionally, an explanation of the value label of the scale and criteria used to compute the dependent variables used in the study are given. These variables are accuracy (global accuracy, verb accuracy, article accuracy) and culture content knowledge.

The statistical significance of the variables was analyzed using the parametric one-way ANOVA tests that were run using the SPSS program. For the accuracy analysis with three measures the ANOVA tests were performed after finding statistical significance with MANOVA, in order to protect against error inflation. However, ANOVA methods require particular assumptions. The first assumption is equal variance, which is assessed using the Levene Test. Significant $\mathrm{p}$ values from a Levene Test indicate that the equal variance assumption is violated. The second assumption is that the observation errors are normally distributed. A histogram of the residuals was used to determine whether the observation errors were approximately normally distributed (Cramer, 1998.p. 69). 
The non-parametric Mann Whitney Test was used when either the equal variance or normality assumptions were violated. However, when the one-way ANOVA and Mann Whitney Test provided the same conclusions, the one-way ANOVA results are also included.

These results answered research questions number one and number two. Research question number three is a qualitative piece of this study. To present results for research question number three, the investigator analyzed the responses of a questionnaire completed by the Spanish instructors. Lastly, a discussion is given after the analyses of the research questions.

\section{Data Collecting}

A demographic instrument (see Appendix H) was applied to the Spanish 204 sections involved in this investigation: age, origin, sex, and student year at the university (freshman, sophomore, junior, and senior) was collected for students enrolled in the sections that participated in this study. The demographic information was distributed as indicated in Figures 4-7. In figures 6 and 7, NR stands for (no response). 


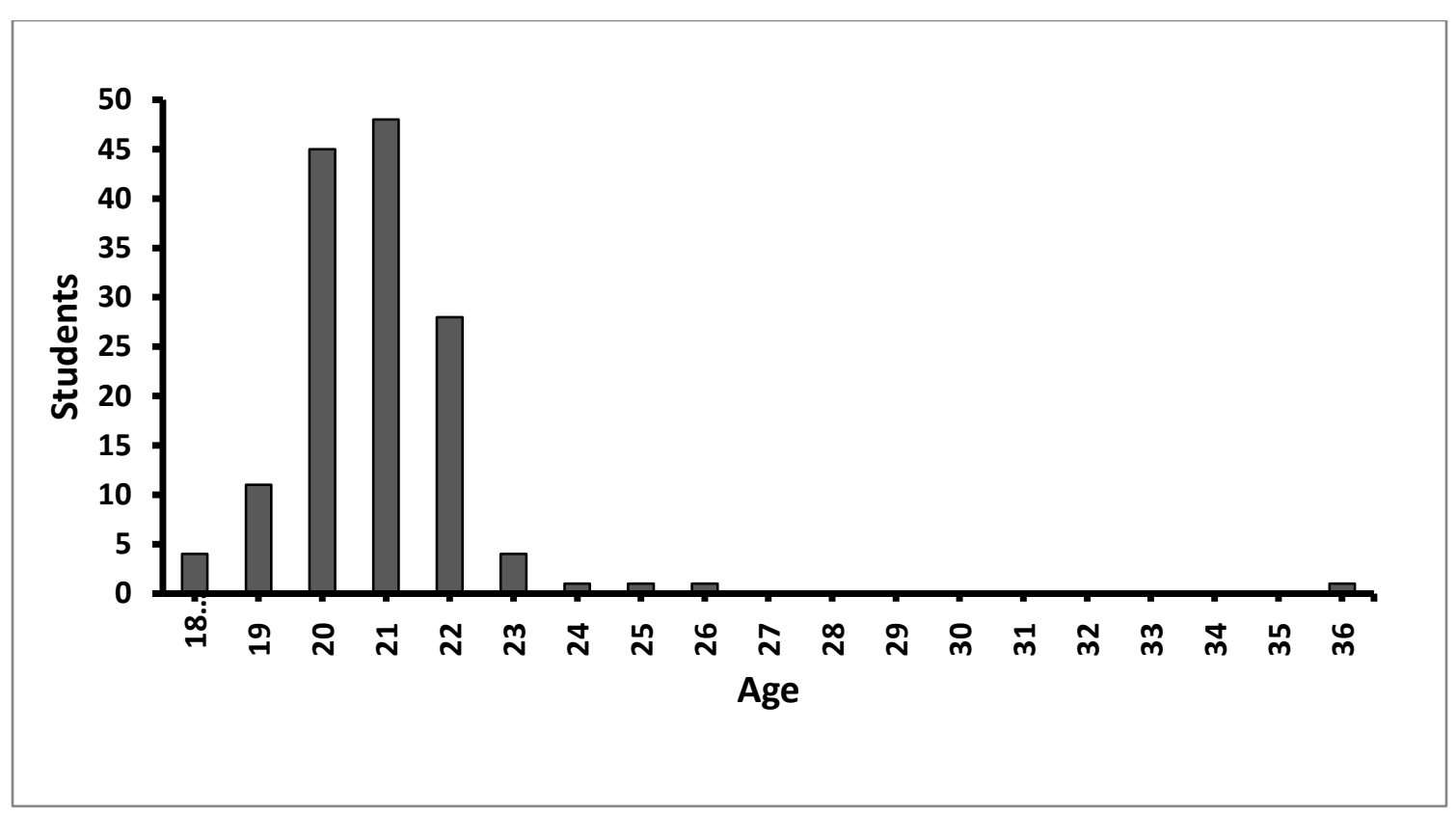

Figure 4. Distribution of age of the all students of Spanish 204 sections who participated in this study.

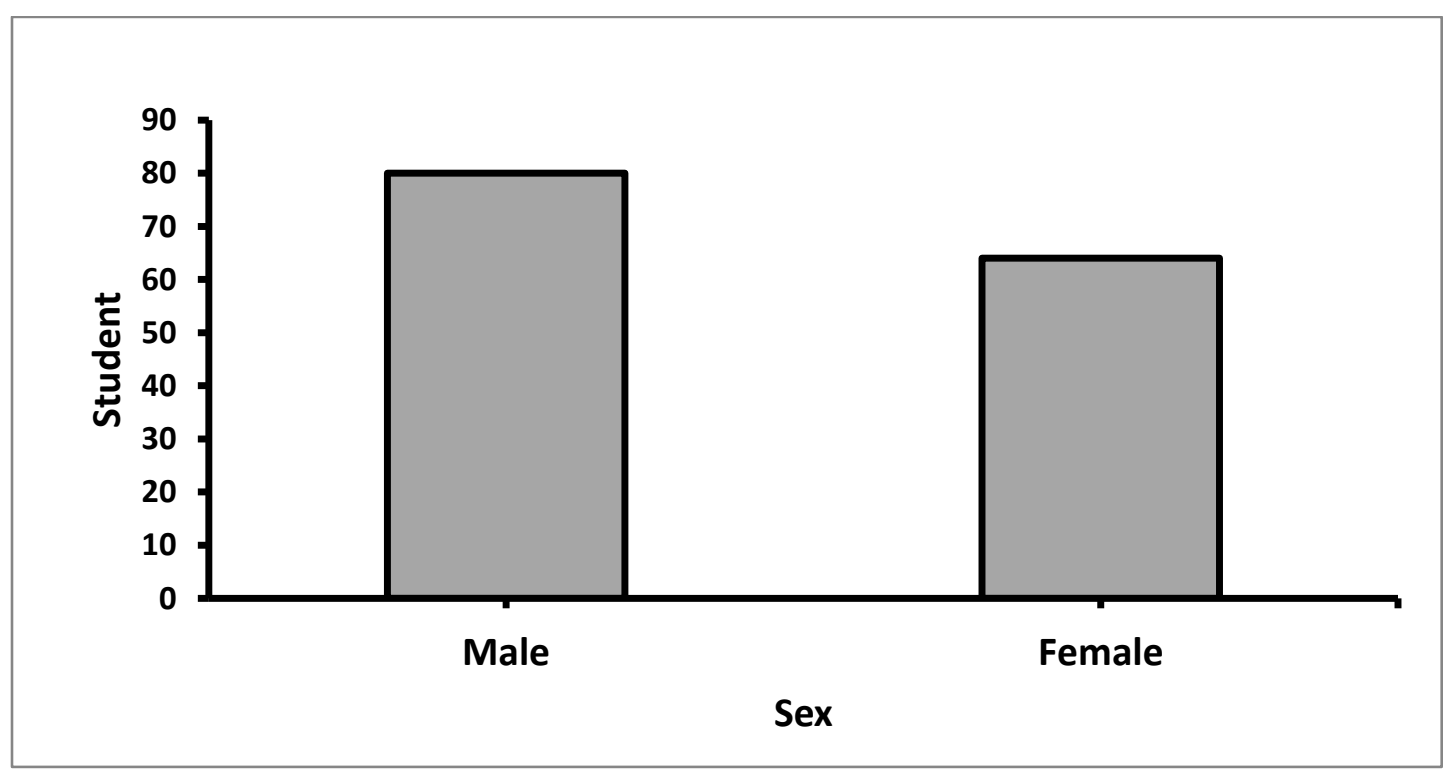

Figure 5. Distribution of sex of all students of Spanish 204 sections who participated in this study. 


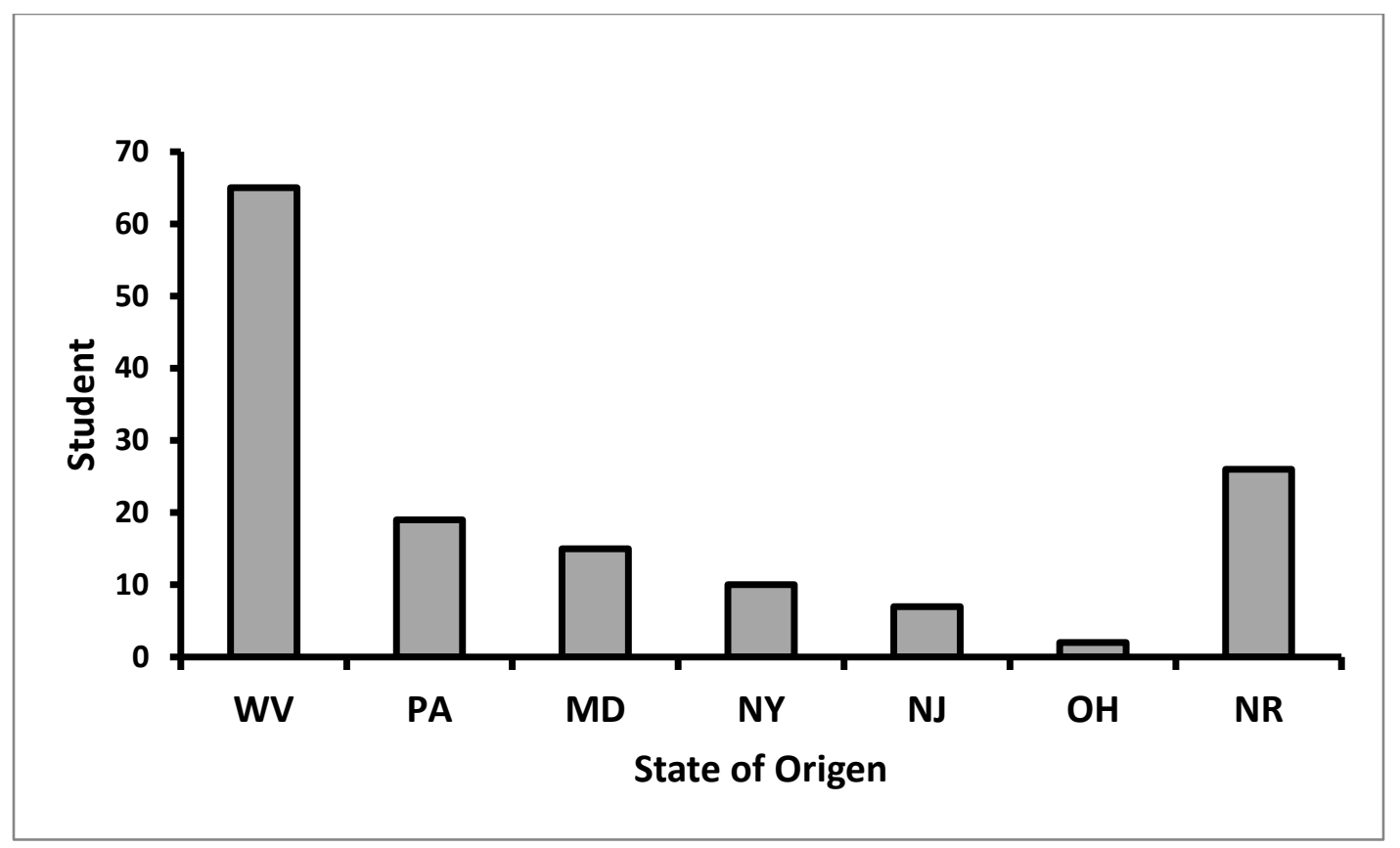

Figure 6. Distribution of State Origin of all students of Spanish 204 sections who participated in this study.

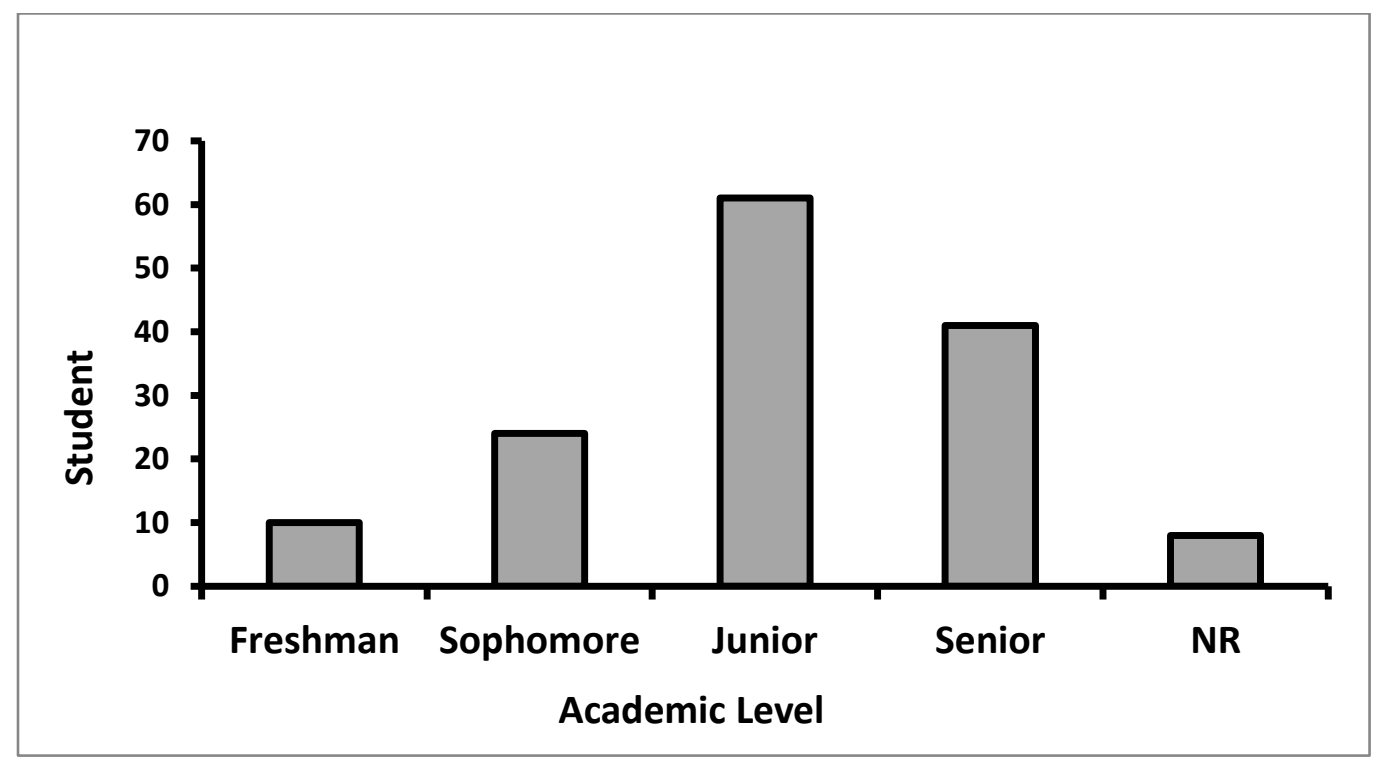

Figure 7. Distribution of academic level of all students of Spanish 204 sections who participated in this study.

Figure 4 shows that the majority of students are between 19 and 22 years old. The number of males exceeds the number of females, as is shown in Figure 5. Most of the students 
are from West Virginia, Pennsylvania and Maryland, though a considerable portion of students did not respond to this question (see Figure 6). Figure 7 shows that the sections that participated in this study are mainly composed of juniors and seniors.

The first part of the data collection was to obtain 57 videos recorded by the instructors during poster project presentations. The participants of both the experimental and control groups were clearly identified using several methods. One method used to identify students was the order in which participants spoke during their oral presentation, and the other method was the characteristics linked to the clothing that participants wore during the presentation. In this way the investigator easily recognized if the participant belonged to the experimental group or control group.

The videos of the ICS task and the videos of the poster project presentation confirmed to the investigator that the presentation procedure (see Appendixes J) was accomplished correctly. Three videos, one experimental and two controls were eliminated because it was impossible for the investigator to see the faces or to hear the speech of these participants during their oral performance.

In this analysis the investigator used the first fives sentences produced by the participants that were not read from notes or other material during the poster project presentation. The investigator chose five sentences, which was the fewest number of sentences that participants were indicated to produce during the ICS task presentation (see Appendix C). In this way, the oral performance during the ICS task and during the poster project presentation had similar requirements and could be measured similarly. The sentences counted could be presented at the beginning, middle or at the end of the speech in the poster project presentation. The first sentence produced was considered as number one, the second sentence number two, and so on until the 
participant completed five sentences. This information was transcribed to the instrument presented in the Table 12 called "global accuracy" that was prepared for collecting the information of the dependent variable accuracy.

The minimum requirement for the sentences was subject, verb, and object. Verbs had to be conjugated in agreement with the subject (noun or subject pronoun), and also, in the correct tense and mood. The articles used in the sentences had to agree in gender (feminine/masculine) and number (singular/plural) to be considered as non-errors. Omissions of verbs and articles were taken as errors. With this information, the investigator completed the instrument, presented in Chapter 3, Table 13, that are called specific accuracy of "verbs accuracy," and "articles accuracy" that were prepared for collecting the information about the dependent variable accuracy.

The points assigned in the culture section of the final exam were used for the analysis of the cultural content knowledge. In the 2014 Spring semester the final exam involved a total of five points for the section of culture. This information was used for the instrument prepared for culture content knowledge and presented in the Table 14, Chapter 3.

All of the statistical analyses were performed with the Statistical Program for the Social Science (SPSS) software. The value for the independent variable ICS task was 1 and 2. The value $1=$ No ICS task C, means that no ICS task was applied to the control group and the value $2=$ ICS task E, means that the ICS task was applied to the experimental group.

There are three measures related to accuracy: global accuracy of error free clauses, specific accuracy for verbs, and specific accuracy for articles. The value of global accuracy ranges from 0 to 5 , where the value of $=0$ means that the participant did not produce any sentences during the poster project presentation because he/she read/omit/with errors. A value of 
$=1$ means that the participant produced 1 sentence error-free in the target language during the poster project presentation; the rest was read/omit/with errors. A value of $=2$ means that the participant produced 2 sentences error-free during the poster project presentation; the rest of the sentences were read/omit/with errors. A value of $=3$ means that the participant produced 3 sentences error-free during the poster project presentation; the rest of the sentences were read/omit/with errors. A value of $=4$ means that the participant produced 4 sentences error-free during the poster project presentation; the fifth sentence was read/omit/with errors. A value of $=$ 5 means that the participant produce 5 sentences error-free during the poster project presentation without reading from notes, omission or errors.

The values for specific accuracy of verbs and articles were similar to those used for global accuracy, with a range from 0 to 5. Thus, for the verb and article accuracy, a value of $=0$ means that the participant did not produce any verb or any article error-free or omit them in the sentences. A value of $=1$ means that the participant produced 1 verb or 1 article error-free in the sentences. A value of $=2$ means that the participant produced 2 verbs or 2 articles error-free in the sentences. A value of $=3$ means that the participant means produced 3 verbs or 3 articles error-free in the sentences. A value of $=4$ means that the participant produced 4 verbs or 4 articles error-free in the sentences. A value of $=5$ means that the participant produced 5 verbs or 5 articles error-free in the sentences.

\section{Analysis of the Dependent Variable Accuracy}

The dependent variable accuracy was measured by using global accuracy of error free clauses, specific accuracy for verbs, and specific accuracy for articles. Before performing three individual ANOVA tests, a MANOVA was performed using all three measures to protect against error inflation. 
Table 18

MANOVA Tests Global Accuracy, verb accuracy and articles accuracy

\begin{tabular}{rrrrrrr}
\hline Effect & & Value & F & Hypothesis df & Error df & Sig \\
\hline Intercept & Pillai ‘s Trace. & .646 & $32.217^{\mathrm{b}}$ & 3.000 & 53.000 & .000 \\
& Wilks'Lambda & .354 & $32.217^{\mathrm{b}}$ & 3.000 & 53.000 & .000 \\
& Hottelling's & 1.824 & $32.217^{\mathrm{b}}$ & 3.000 & 53.000 & .000 \\
& $\begin{array}{r}\text { Trace } \\
\text { ICS task }\end{array}$ & 1.824 & $32.217^{\mathrm{b}}$ & 3.000 & 53.000 & .000 \\
& $\begin{array}{r}\text { Roy ‘s Largest } \\
\text { Root }\end{array}$ & .159 & $3.329^{\mathrm{b}}$ & 3.000 & 53.000 & .026 \\
& $\begin{array}{r}\text { Pillai ‘s Trace } \\
\text { Wilks'Lambda }\end{array}$ & .841 & $3.329^{\mathrm{b}}$ & 3.000 & 53.000 & .026 \\
& $\begin{array}{r}\text { Hottelling's } \\
\text { Trace }\end{array}$ & .188 & $3.329^{\mathrm{b}}$ & 3.000 & 53.000. & .026 \\
& $\begin{array}{r}\text { Roy 's Largest } \\
\text { Root }\end{array}$ & .188 & $3.329^{\mathrm{b}}$ & 3.000 & 53.000 & .026 \\
\hline
\end{tabular}

a. Design: intercept + ICS task

b. Exact statistic

A significant difference in mean accuracy can be found between the groups that did the ICS task and the control group, for at least one of the accuracy variables, Wilks' Lambda $=$ $0.841, \mathrm{df}=(3,53)$ and $p$ value $=0.026$. Thus, the individual ANOVA tests are performed in what follows.

\section{Analyses of Global Accuracy}

As was explained before, accuracy was measured by using global accuracy based on number of sentences that were error-free, and specific accuracy based on number of sentences with articles and verbs that were error-free. A one-way ANOVA was performed to compare the global accuracy of experimental and control groups. Fourteen participants performed two ICS tasks before the poster project presentation at the end of the semester (the experimental group) and 43 participants did not do the ICS task (the control group). 
Table 19 and the boxplots in Figure 9 show that the experimental group had a greater numbers of error free clauses than the control group, on average. Table 20 shows that the Levene test for homogeneity of variance is not significant, $p$ value $=0.156$, which means that we cannot detect unequal variance between groups. The Normality assumption was analyzed by constructing a histogram of the ANOVA residuals to see if their distribution is approximately normal, see Figure 8. Since the histogram of Figure 8 reveals non-normality in the residuals, a non-parametric Mann-Whitney test (Table 22) was performed obtaining a significant $p$ value $=$ 0.029. Thus, there is a significant difference between the number of error free clauses between the control and experimental groups.

Table 19

ANOVA Global Accuracy Descriptive

\begin{tabular}{|c|c|c|c|c|c|c|c|c|}
\hline & \multirow[b]{2}{*}{$\mathrm{N}$} & \multirow[b]{2}{*}{ Mean } & \multirow[b]{2}{*}{ Std. Deviation } & \multirow[b]{2}{*}{ Std. Error } & \multicolumn{2}{|c|}{$\begin{array}{l}\text { 95\% Confidence Interval for } \\
\text { Mean } \\
\end{array}$} & \multirow[b]{2}{*}{ Min. } & \multirow[b]{2}{*}{ Max } \\
\hline & & & & & Lower Bound & Upper Bound & & \\
\hline No ICStaskC & 43 & 1.81 & 1.816 & .277 & 1.26 & 2.37 & 0 & 5 \\
\hline ICStaskExp & 14 & 3.00 & 1.519 & .406 & 2.12 & 3.88 & 0 & 5 \\
\hline Total & 57 & 2.11 & 1.810 & .240 & 1.63 & 2.59 & 0 & 5 \\
\hline
\end{tabular}

Table 20 Levene Test of Homogeneity of Variances

\begin{tabular}{cccc}
\hline Levene Statistic & df1 & df2 & Sig. \\
\hline 2.071 & 1 & 55 & .156 \\
\hline
\end{tabular}


Table 21

ANOVA test Global Accuracy

\begin{tabular}{lccccc}
\hline & Sum of Squares & df & Mean Square & $F$ & Sig. \\
\hline Between Groups & 14.857 & 1 & 14.857 & 4.849 & .032 \\
\hline & & & & & \\
Within Groups & 168.512 & 55 & 3.064 & & \\
Total & 183.368 & 56 & & & \\
\hline
\end{tabular}

Table 21 displays the results of the ANOVA for global accuracy. A significant difference between the groups that did the ICS task and the control group was found, $\mathrm{F}=4.849, \mathrm{df}=(1,55)$ and $p$ value $=0.032$. Thus, the conclusion is the same for the Mann Whitney test as the for ANOVA; the results from this study allow the author to reject the null hypothesis, which states there is no effect of the ICS task in L2s' accuracy in oral poster presentations.

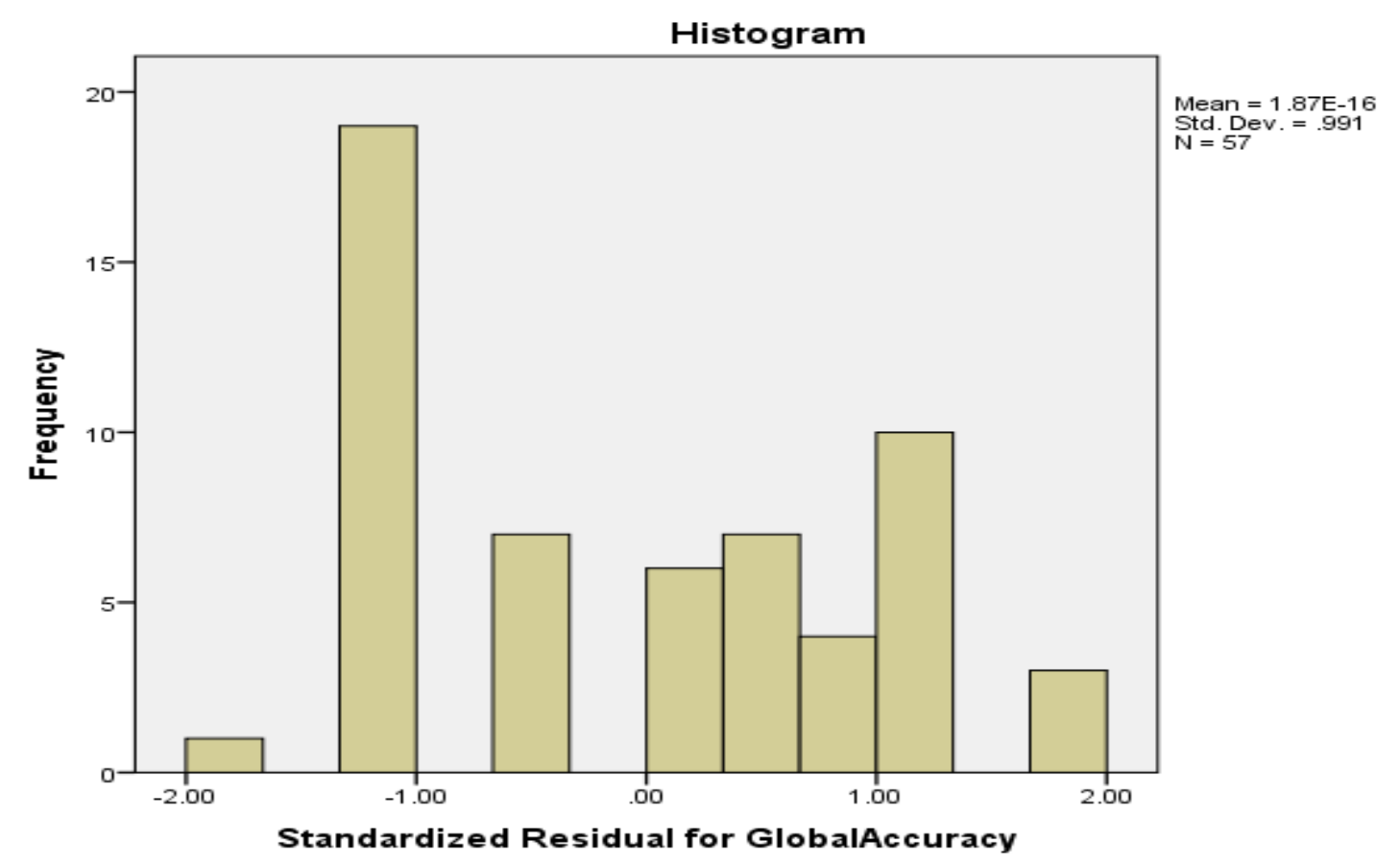

Figure 8. A histogram of the ANOVA residuals of global accuracy. This histogram reveals nonnormality in the residuals 
Table 22

Mann Whitney Test for Global Accuracy

\begin{tabular}{lc}
\hline & GlobalAccu \\
\hline Mann-Whitney U & 186.500 \\
Wilcoxon W & 1132.500 \\
& -2.187 \\
Asymp. Sig. (2-tailed) & .029 \\
\hline
\end{tabular}

a. Grouping Variable: ICSTASK

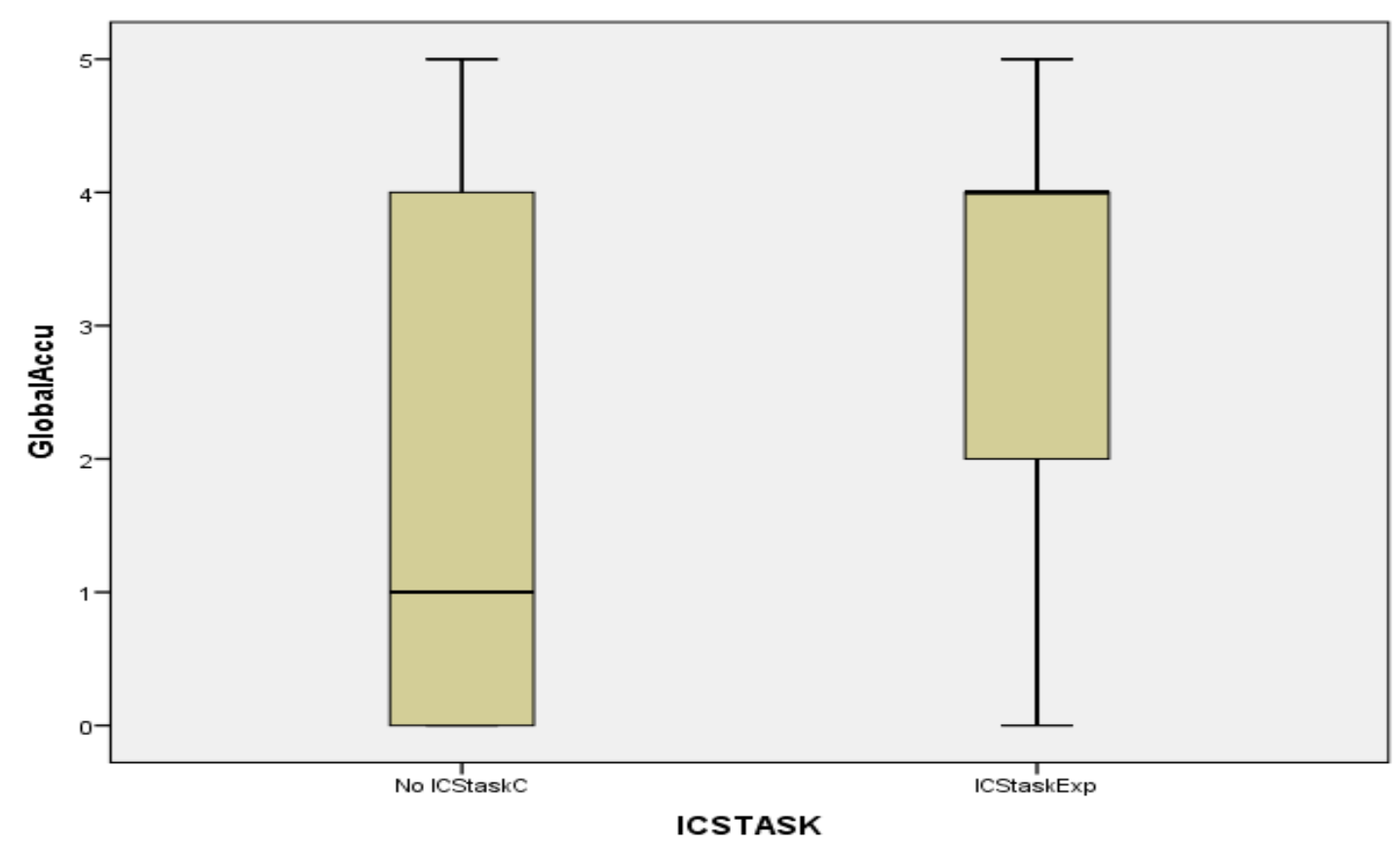

Figure 9. Distribution of global accuracy in the control and experimental group.

\section{Analysis of Specific Measure of Verb Accuracy}

Table 23 and the boxplots in Figure 11 show that the experimental group had a greater numbers of error free clauses than the control group, on average. Table 24 shows that the Levene test for homogeneity of variance is not significant with a $p$ value $=0.958$, which means that we cannot detect unequal variance between groups. To see if the residuals have an approximately normal distribution, a histogram was constructed (see Figure 11). 
Table 23

ANOVA Verbs Accuracy Descriptive

\begin{tabular}{|c|c|c|c|c|c|c|c|c|}
\hline & \multirow[b]{2}{*}{$\mathrm{N}$} & \multirow[b]{2}{*}{ Mean } & \multirow[b]{2}{*}{ Std. Deviation } & \multirow[b]{2}{*}{ Std. Error } & \multicolumn{2}{|c|}{$\begin{array}{l}\text { 95\% Confidence Interval for } \\
\text { Mean } \\
\end{array}$} & \multirow[b]{2}{*}{ Min. } & \multirow[b]{2}{*}{ Max. } \\
\hline & & & & & Lower Bound & Upper Bound & & \\
\hline No ICStaskC & 43 & 2.42 & 2.452 & .374 & 1.66 & 3.17 & 0 & 7 \\
\hline ICStaskExp & 14 & 4.57 & 2.503 & .669 & 3.13 & 6.02 & 0 & 8 \\
\hline Total & 57 & 2.95 & 2.615 & .346 & 2.25 & 3.64 & 0 & 8 \\
\hline
\end{tabular}

Table 24

Levene test: Test of Homogeneity of Variances (verbs accuracy)

\begin{tabular}{cccc}
\hline Levene Statistic & $\mathrm{df1}$ & $\mathrm{df2}$ & Sig. \\
\hline .003 & 1 & 55 & .958 \\
\hline
\end{tabular}

Table 25

ANOVA test verbs accuracy

\begin{tabular}{lccccc}
\hline & Sum of Squares & df & Mean Square & $\mathrm{F}$ & Sig. \\
\hline Between Groups & 48.948 & 1 & 48.948 & 8.063 & .006 \\
Within Groups & 333.894 & 55 & 6.071 & & \\
Total & 382.842 & 56 & & & \\
\hline
\end{tabular}

Since the histogram in Figure 10 reveals non-normality in the residuals, the nonparametric Mann-Whitney test was performed (see Table 26), and again a similar significant conclusion was found for this test $(p$ value $=0.008)$ and for the ANOVA $(\mathrm{F}=8.063 \mathrm{df}=1,5$ and the $p$ value $=0.006$ ). Thus, the results from this study allow the author to reject the null hypothesis, which states there is no effect of the ICS task in accuracy in oral poster presentation. 


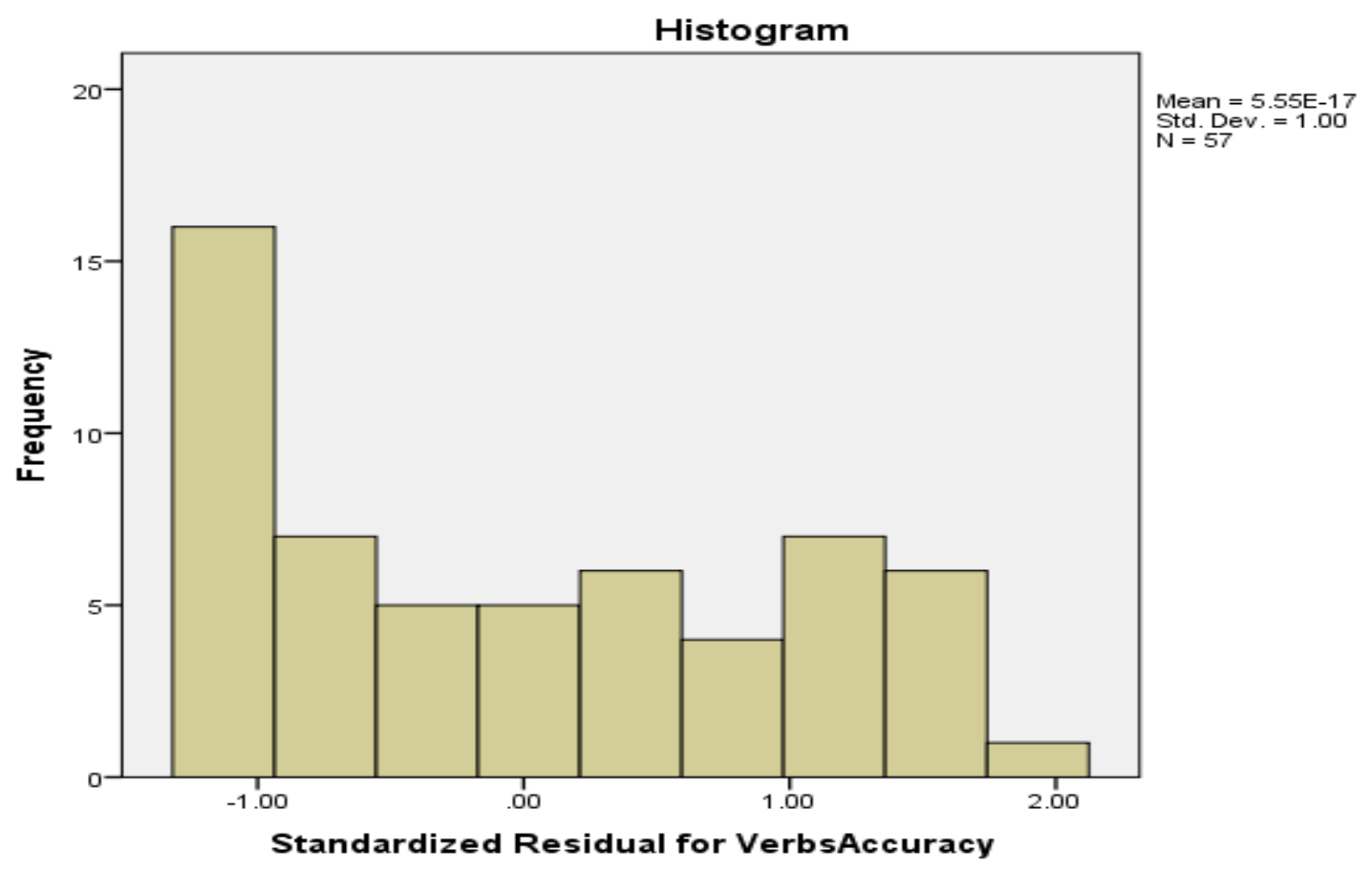

Figure 10. A histogram of ANOVA residuals for verb accuracy. This histogram reveals nonnormality in the residuals.

Table 26

Mann Whitney Test for Verbs Accuracy ${ }^{\mathrm{a}}$

\begin{tabular}{lc}
\hline & Verbs \\
& Accu \\
\hline Mann-Whitney U & 159.000 \\
Wilcoxon W & 1105.000 \\
Z & -2.672 \\
Asymp. Sig. (2-tailed) & .008 \\
\hline
\end{tabular}

a. Grouping Variable: ICSTASK 


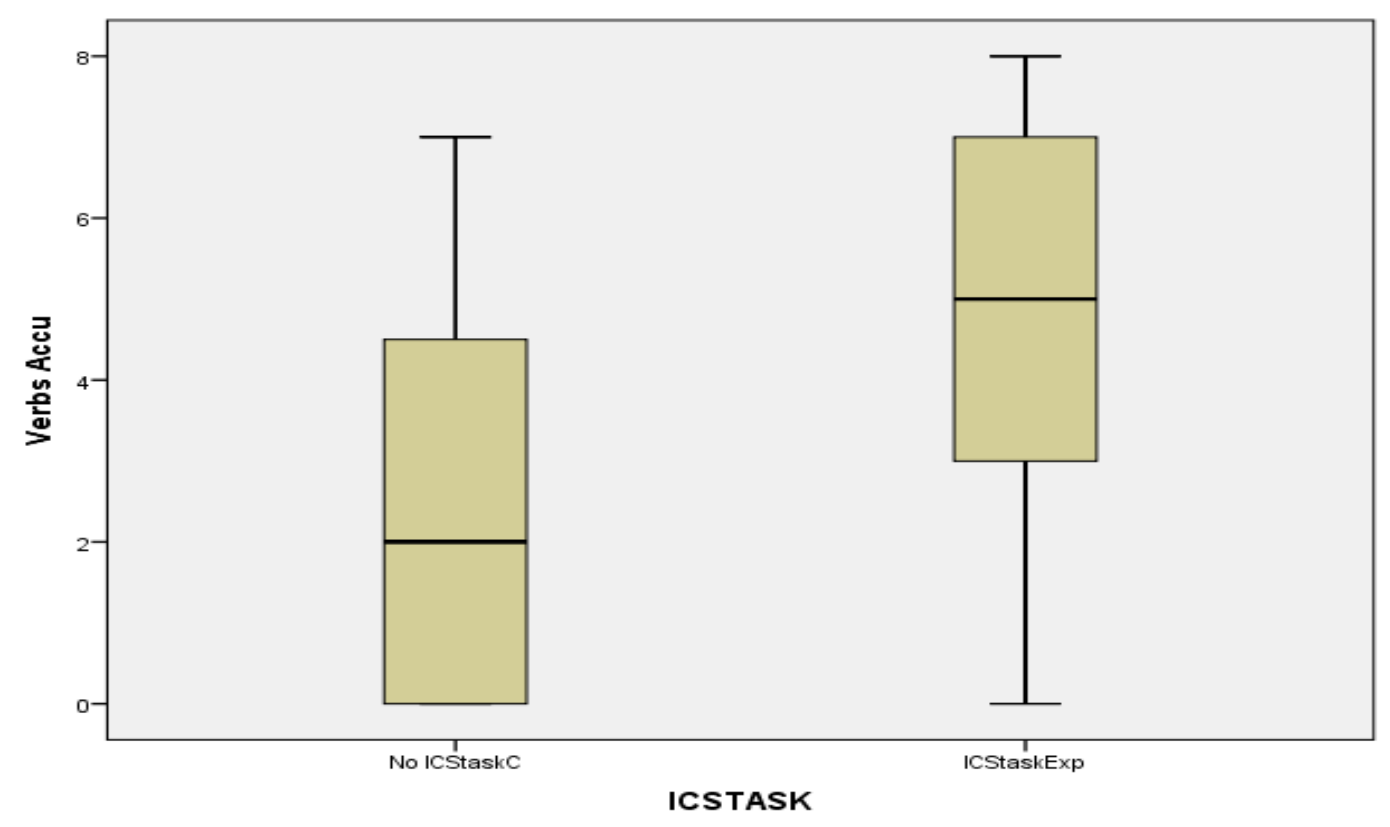

Figure 11. Distribution of the verb accuracy in the control and experimental groups.

\section{Analysis of Specific Measure of Article Accuracy}

Table 27 and the boxplots in Figure 13 show that the experimental group had a slightly higher level of articles accuracy than the control group, on average, though this difference will be shown to be non-significant. Table 28 shows that the Levene test for homogeneity of variance is not significant, $\mathrm{p}$ value $=0.609$, which means we cannot detect an unequal variance between groups. To see if the residuals have an approximately normal distribution, a histogram was constructed (see Figure 12).

Table 27

ANOVA of Articles Accuracy Descriptive

\begin{tabular}{|c|c|c|c|c|c|c|c|c|}
\hline & \multirow[b]{2}{*}{$\mathrm{N}$} & \multirow[b]{2}{*}{ Mean } & \multirow[b]{2}{*}{ Std. Deviation } & \multirow[b]{2}{*}{ Std. Error } & \multicolumn{2}{|c|}{$\begin{array}{l}\text { 95\% Confidence Interval for } \\
\text { Mean }\end{array}$} & \multirow[b]{2}{*}{ Min. } & \multirow[b]{2}{*}{ Max. } \\
\hline & & & & & Lower Bound & Upper Bound & & \\
\hline No ICStaskC & 43 & 2.95 & 3.505 & .534 & 1.87 & 4.03 & 0 & 11 \\
\hline ICStaskExp & 14 & 4.14 & 3.394 & .907 & 2.18 & 6.10 & 0 & 11 \\
\hline Total & 57 & 3.25 & 3.486 & .462 & 2.32 & 4.17 & 0 & 11 \\
\hline
\end{tabular}


Table 28

Levene test of Homogeneity of Variances (articles accuracy)

\begin{tabular}{cccc}
\hline Levene Statistic & $\mathrm{df1}$ & $\mathrm{df2}$ & Sig. \\
\hline .265 & 1 & 55 & .609 \\
\hline
\end{tabular}

Table 29

ANOVA test of articles accuracy

\begin{tabular}{lccccc}
\hline & Sum of Squares & df & Mean Square & $\mathrm{F}$ & Sig. \\
\hline Between Groups & 14.940 & 1 & 14.940 & 1.234 & .271 \\
Within Groups & 665.621 & 55 & 12.102 & & \\
Total & 680.561 & 56 & & & \\
\hline
\end{tabular}

Since the histogram in Figure 12 reveals non-normality in the distribution of the groups, a non-parametric Mann-Whitney test was performed (see Table 30). A no significant conclusion was found for this test $(p$ value $=0.103)$ and for $\operatorname{ANOVA}(\mathrm{F}=1.234 \mathrm{Df}=1$ and the $p$ value $\mathrm{p}=$ 0.271). Thus with these results, the author failed to reject the null hypothesis that states there is no effect of the ICS task in L2s' accuracy in the oral poster presentation. 


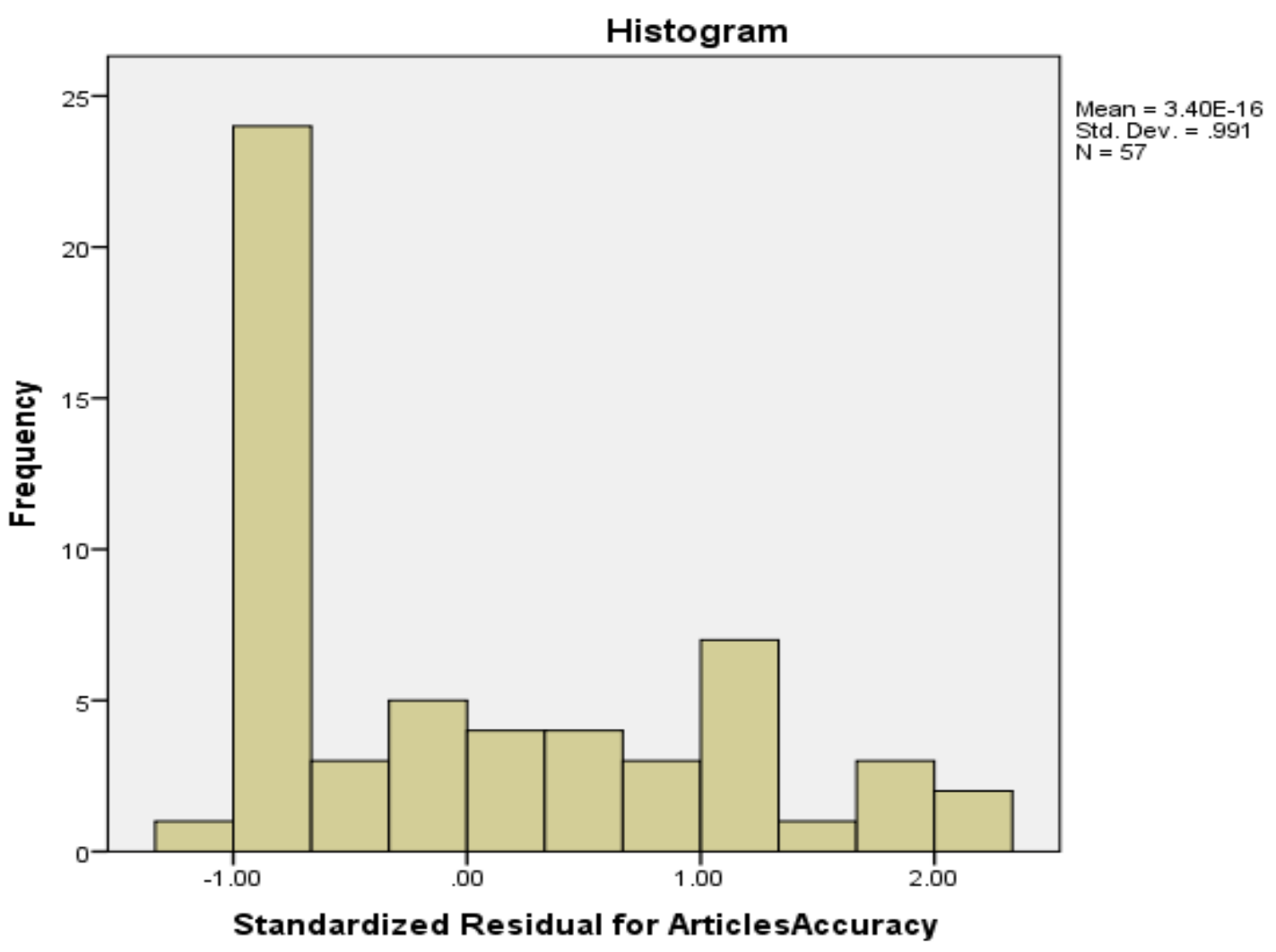

Figure 12. A histogram of ANOVA residuals for article accuracy. This histogram reveals non-normality in the residuals.

Table 30

Mann Whitney Test of Article Accuracy ${ }^{\mathbf{a}}$

ArticlesAccu

Mann-Whitney U

215.500

Wilcoxon $\mathrm{W}$

1161.500

Z

$-1.630$

Asymp. Sig. (2-tailed)

.103

a. Grouping Variable: ICSTASK 


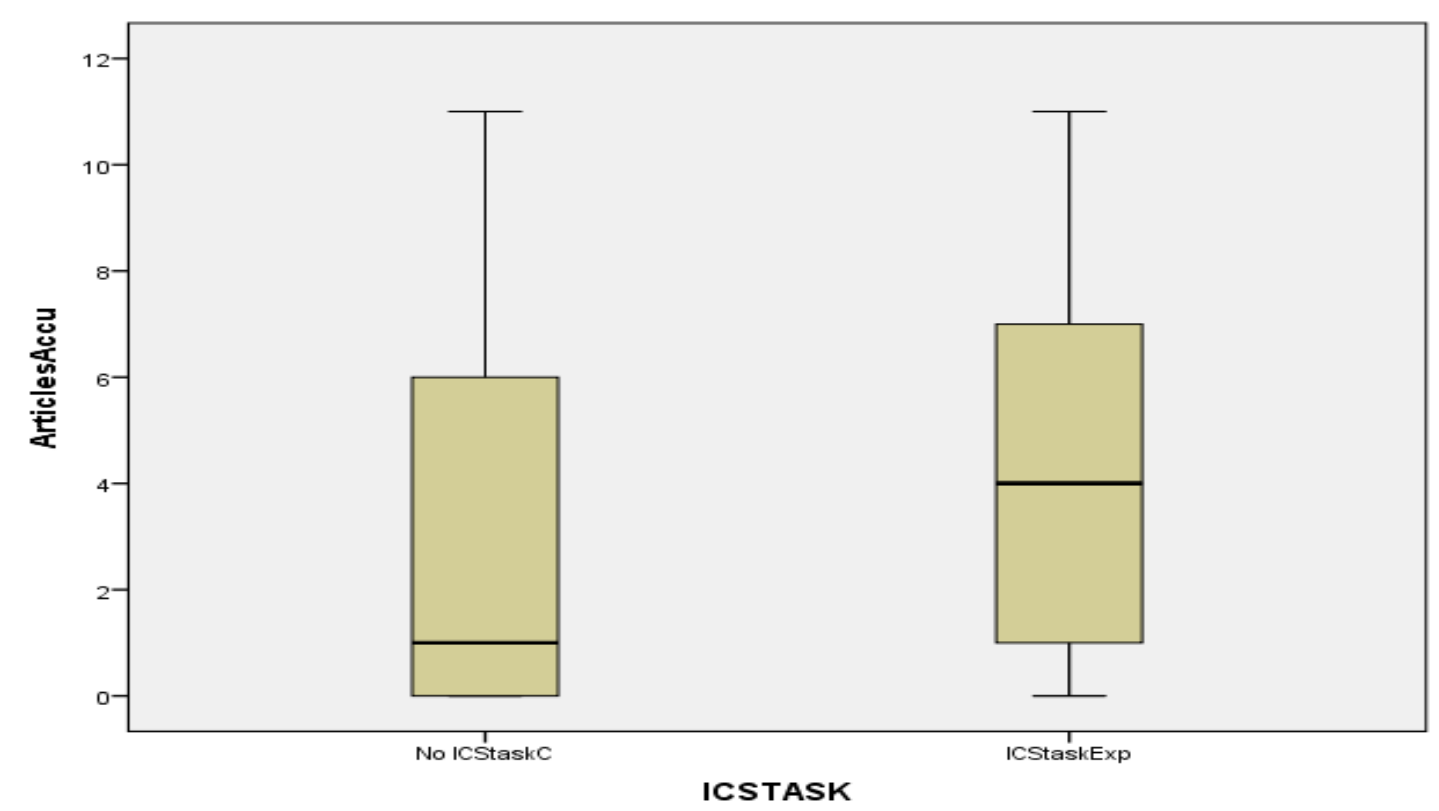

Figure 13. Distribution of the article accuracy in the control and experimental groups.

\section{Research Question \# 1}

Does a set of two ICS tasks in the experimental group as opposed to the absence of these tasks in a control group result in a statistically significant difference in accuracy in the oral poster presentation?

\section{Discussion}

The present discussion begins with research regarding certain factors that influence the speaking process in second language acquisition, then continues with insights about the acquisition of articles and verbs in Spanish related to the statistical results of this study obtained from the control and experimental groups. The results for article accuracy were statistically no significant, but the results for verb accuracy were determined to be significant.

The ability to speak is a "complex skill" that involves a "mental chronology;" it is "not instantaneous," and it is "based on the interaction of a set of processing components that are relatively autonomous or modular in their functioning" (Levelt, 1995, p.14). Levelt's model of 
L1 oral production described four components in the generation of speech as follows: 1)

Conceptual preparation (choosing the message), which is related to deciding what to express.

The speaker organizes the content according to linearization and perspective. Linearization is the process by which the speaker orders the information to be expressed, and perspective depends on spatial relationships. 2) Formulating (preverbal message) refers to performing the grammatical and phonologic/phonetic encoding. Levelt states that in grammatical encoding, "the lexicon has a specification for the syntactic environment it requires" (p. 17). Thus, speakers have to use different verbs, adjectives, prepositions, and nouns and use them in a precise syntactic context. Phonological encoding requires the speaker to access the phonological syllables of each work through syllabification and cue the production of the articulatory gesture of each sound. 3) Articulation, which refers to "the articulatory gesture, is a highly sophisticated system that controls the movement of lung, larynx, pharynx and mouth" in order to speak (p.21). 4) Selfmonitoring, when speakers detect troubles in their speech and attempt to correct them, is a threephase process. The first phase happens when the speaker makes an error and decides it is significant enough to merit pausing and correcting. The second phase, or the editing phase, is signaled by an "editing term" such as "er" or "sorry." The third phase involves a re-start followed by the correct word or grammatical structure (Levelt, 1995).

As previously explained in this study, L1 oral production is a parallel, highly automatic process. That is, "as soon as the Conceptualizer passes information to the Formulator, the Conceptualizer stars to work on the next piece of information regardless of the fact that the last piece of information is still being processed by the Formulator" (Wang, 2014, p.28).

However, speech production in L2 is constrained by such factors as real-time pressure, since working memory capacity is thought to be limited, and lack of sufficient L2 resources 
(Skehan, 2014) depending on the speaker's interlanguage. Therefore, another factor to consider is the role of interlanguage in second language acquisition. According to Brown (1976), in the interlanguage there exists a pattern of errors that our students make, this pattern changes overtime as the learner becomes more proficient in the second language. However, some errors could fossilize that is: "the interlanguage ceases to develop at some point short of full identity with the target language" (Tarone 2006, p. 747). Fernandez (1995) proposed the following didactic interventions for transitory errors and fossilized errors during the interlanguage process: 1) use interactive practices in the classroom, 2) make students conscious of their errors, and 3) analyze the cause of the errors. The second of these pedagogical tactics relates to Ortega's (1999) claims regarding planning:

Planning before doing an L2 task can promote an increased focus on form by providing space for the learner to devote conscious attention during pre-task planning to formal and systemic aspects of the language needed to accomplish a particular task (p.109).

The design of the ICS task investigated in this study incorporates all three of Fernandez's (1995) suggestions. Interactive practice occurs when students do cultural oral presentations and answer the open-ended questions at the end of the presentation. The students had planning time and guidance to prepare the ICS task, which afforded them ample opportunity to be made aware of their errors and correct them before the final oral presentation. To analyze the cause of errors, the students' presentations were recorded and transcribed; the relevant errors were then analyzed in the light of research regarding article and verb accuracy. Table 31 shows a sample of errors that were observed during the evaluation of the students' videos. 
Table 31

Example of Errors that Learners Made During Oral Production

\begin{tabular}{|c|c|}
\hline Omission of Article/Articles Errors & Omission of Verbs/Verb Errors \\
\hline $\begin{array}{l}\text { Se celebra } \underline{\mathbf{0 0}} 10 \text { de noviembre. I } \\
\text { Se celebra } \underline{\text { el }} 10 \text { de noviembre. C }\end{array}$ & $\begin{array}{l}\text { El fútbol se juego como deporte. I } \\
\text { El fútbol se jugó como deporte. C }\end{array}$ \\
\hline $\begin{array}{l}\text { J.L. empezó su carrera como un bailarina. I } \\
\text { J.L. empezó su carrera como una bailarina. } \mathbf{C}\end{array}$ & $\begin{array}{l}\text { Dalí está un poco loco. I } \\
\text { Dalí estaba un poco loco. C }\end{array}$ \\
\hline $\begin{array}{l}\text { Es un estilo musical con énfasis en la guitarra, } \\
\text { la voz y la ritmo. I } \\
\text { Es un estilo musical con énfasis en la guitarra, } \\
\text { la voz y el ritmo C }\end{array}$ & $\begin{array}{l}\text { Cuando es mucho calor afuera. I } \\
\text { Cuando hace mucho calor afuera. C }\end{array}$ \\
\hline $\begin{array}{l}\text { Ellos usan los manos. I } \\
\text { Ellos usan las manos. C }\end{array}$ & $\begin{array}{l}\text { En España es tres comidas típicas. I } \\
\text { En España hay tres comidas típicas .C }\end{array}$ \\
\hline $\begin{array}{l}\text { Ellos les ayudan con las problemas por } \\
\text { ejemplo económicos y criminales. I } \\
\text { Ellos les ayudan con los problemas por } \\
\text { ejemplo económicos y criminales. C }\end{array}$ & $\begin{array}{l}\text { Platos nuevos ha sido incorporados. I } \\
\text { Platos nuevos } \underline{\text { han sido incorporados. C }}\end{array}$ \\
\hline $\begin{array}{l}96 \% \text { practican la catolicismo. I } \\
96 \% \text { practican } \underline{\text { el catolicismo. C }}\end{array}$ & $\begin{array}{l}\text { El equipo del Real Madrid juegan en } \\
\text { el estadio Santiago Bernabéu. I } \\
\text { El equipo del Real Madrid juega en el } \\
\text { estadio Santiago Bernabéu. C }\end{array}$ \\
\hline $\begin{array}{l}\text { Otra de los festividades más importantes de } \\
\text { Puerto Rico es la Navidad. I } \\
\text { Otra de las festividades más importantes de } \\
\text { Puerto Rico es la Navidad. C }\end{array}$ & $\begin{array}{l}\text { Es muy bien I } \\
\text { Está muy bien. C }\end{array}$ \\
\hline
\end{tabular}




\begin{tabular}{|c|c|}
\hline $\begin{array}{l}\text { El dulce de leche es la leche y } \underline{\mathbf{0 0}} \text { azúcar. C } \\
\text { El dulce de leche es la leche y } \underline{\mathbf{e l}} \text { azúcar. I }\end{array}$ & $\begin{array}{l}\text { Se bebida con los amigos. I } \\
\text { Se bebe con los amigos. C }\end{array}$ \\
\hline $\begin{array}{l}\text { Querían cosas valiosas como } \underline{\mathbf{0 0}} \text { oro y la } \\
\text { plata. I } \\
\text { Querían cosas valiosas como el oro y } \\
\text { la plata. C }\end{array}$ & $\begin{array}{l}\text { La mayoría de los luchadores son } \\
\text { borrachos. I } \\
\text { La mayoría de los luchadores están } \\
\text { borrachos. C }\end{array}$ \\
\hline $\begin{array}{l}\text { Le recomiendo que ordene } \underline{\text { los hallacas. I }} \\
\text { Le recomiendo que ordene } \underline{\text { las }} \text { hallacas. C }\end{array}$ & $\begin{array}{l}\text { Gaudí era inconsciente en la calle. I } \\
\text { Gaudí estaba inconsciente en la calle. } \\
\text { C }\end{array}$ \\
\hline
\end{tabular}

Source: video scripts of poster project.

Note. $\mathrm{I}=$ incorrect sentences. $\mathrm{C}=$ correct sentences.

The results for article accuracy are similar to the findings of other studies. For the purpose of this study, article errors included incorrect inflection for the gender or number of the article, omission of the article, and the use of the indefinite article when the definite was required and vice-versa.

Isabelli-Garcia (2010) stated the main cause of article errors in the interlanguage of English L1 learners of Spanish is because the English language lacks grammatical gender agreement and consequently it has an effect on the acquisition of Spanish. Students try to overcome this error by referring to the spelling of the noun and prototypical rules regarding grammatical gender in Spanish. One of the most well-known rules is that nouns ending in $\boldsymbol{a}$ are feminine, and nouns ending in $\boldsymbol{o}$ are masculine, for example: la niña and el niño.

Many errors are produced as a result of irregular nouns (e.g., la mano) or nouns that follow a less frequent rule (e.g., all nouns ending in $\boldsymbol{a d}$ are feminine). The following partial transcripts demonstrate the errors that learners are likely to produce: 
They use the [their] hands.

Ellos usan $\underline{\text { los }}$ manos. Incorrect

Ellos usan $\underline{\text { las }}$ manos. Correct

Another one of the most important celebrations in Puerto Rico is Christmas.

Otra de los festividades más importantes de Puerto Rico es la Navidad. Incorrect

Otra de las festividades más importantes de Puerto Rico es la Navidad. Correct

However, even the simple $\boldsymbol{a} / \boldsymbol{o}$ rule is difficult for students to follow consistently; the following example evidences this common error from the participants of this study:

It is a musical style with emphasis on the guitar, the voice and the rhythm.

Es un estilo musical con énfasis en la guitarra, la voz y la ritmo. Incorrect

Es un estilo musical con énfasis en la guitarra, la voz y el ritmo. Correct

Due to the differences in when and how articles are employed in both languages, it is common for English speakers to omit articles in certain contexts. For example:

It is celebrated on November $10^{\text {th }}$.

Se celebra $\underline{\mathbf{0 0}} 10$ de noviembre. I

Se celebra $\underline{\text { el }} 10$ de noviembre. $\boldsymbol{C}$

Fernandez-Garcia (2012) conducted a study with 44 Spanish students: 16 first generation heritage speakers, 14 second generation heritage speakers, and 14 second language Spanish learners. All participants were born in the United States, and were registered to a bilingual school between grades nine and ten where Spanish is a required subject. The participants were shown two sets of six randomly selected drawings related to various social settings (e.g. office, schools, street and home). The students were asked two questions: 1) What do you see in the drawings? 2) What is an interesting experience you remember from when you were in school? 
The results showed that from a total of gender assignment errors, 122 were from second language Spanish learners, 27 from the first generation of heritage speakers and 12 from the second generation of heritage speakers. The tendency was that the masculine article was used with a feminine noun. It is frequent that L2 learners use masculine articles as the default gender when they do not know what to use because is more simple form. The results varied depending on the noun form, for example some cases used feminine for nouns ending with ad, which is correct, but some cases used la problema, instead of $\boldsymbol{e l}$ problema (an irregular masculine noun).

The results revealed that the ICS task, as a planned and guided task, had a significant effect on verb accuracy as measured based on poster project oral presentation. It was found that verbal errors in this investigation were mainly related to the incorrect use of the verbs SER and ESTAR, followed by some incorrect conjugation of the tense (past time: preterit and imperfect) and incorrect conjugation of the indicative mood of the verb. The following paragraphs discuss research that examines the causes for these errors.

According to Gutierrez-Araus (1991) the difficulty that native English speakers who are learning Spanish as a second language face, is that the verb To Be in English has two possible translations in Spanish: the verbs SER and ESTAR. This presents a linguistic problem that sometimes is still present in superior levels. The verbs SER and ESTAR express an attribute of the subject, and the type of attribute indicates if we have to use SER or ESTAR. When the attribute is a "verbal adjective" that expresses a condition (emotional or physical), the best verb to use is ESTAR, and when the attributes are adjectives that express quality the best verb to use is SER. 
The following sentence is an example of an error made by one of the participants during his poster project oral presentation on the Spanish architect Gaudi. Due to the fact that the student was talking about Gaudi's mental state the verb to use was ESTAR.

\section{Gaudi was unconscious in the street.}

Gaudí era inconsciente en la calle. Incorrect verb SER Gaudí estaba inconsciente en la calle. Correct verb ESTAR

Koike \& Klee (2013) stated that incorrect conjugation in the present indicative, as was found in this study, is common because verb structure is more extensive in Spanish than in English. Spanish verbs have a root, a thematic vowel and morphemes that are linked to different subjects, whereas, in English, only in the third person singular form of the verb undergoes a morphological change, which is marked with an -s; therefore, subject-verb agreement is easier.

This is an example of an error found in subject-verb agreement when the participant presented a poster project oral presentation on the Spanish football (soccer) team Real Madrid to the class.

El equipo del Real Madrid juegan en el estadio Santiago Bernabéu. Incorrect (verb - third person plural)

El equipo del Real Madrid juega en el estadio Santiago Bernabéu. Correct (verb third person singular)

Regarding errors with the past tense in Spanish, Koike \& Klee (2013) pointed out that the past tense in Spanish is represented by two verbal forms, preterit and imperfect, and there is a 
correlation between the preterit and punctual and telic events and between the imperfect and events that involve activities or atelic situations. The preterit is presented as a unique event in the past, and the imperfect is presented as a habitual and durative event. It is frequent at the beginning and intermediate levels to see that English speakers use the preterit when they do not know what to use. However, in this study, as students had sufficient planning time and instructor guidance, they generally avoided errors regarding the preterit vs. the imperfect. Here is an example of errors related to past time when the participant performed a poster project oral presentation about The Spanish Conquistadors:

Their saying was "for gold, god and glory."

Su lema 00 "por oro, dios y gloria”. Incorrect omission of the verb

Su lema era "por oro, dios y gloria”. Correct the imperfect form of SER This was played as a sport in China

Esto se juego como deporte en China. Incorrect structure of preterit Esto se jugó como deporte en China. Correct Preterit

An additional idea is that the ICS task involves a narrative, a study showed that the type of narrative "may have an effect" on the selection of the preterit versus the imperfect. In personal narratives the student used the imperfect more, and in fictional narratives they used the preterit more (Salaberry, 2003, p. 561).

\section{Analysis of the Dependent Variable Cultural Content Knowledge}

The variable cultural content knowledge was measured by the points earned by participants on the cultural section of the final exam, out of a possible five points (see appendix I or Table 14 in Chapter 3). 
Table 32 and the boxplots in Figure 15 show that the experimental group scored higher on cultural content knowledge than the control group, on average. Table 33 shows that the Levene test of homogeneity of variance has a significant $p$ value $=0.000$, which indicates that there is a violation of the assumption that the variability in both groups is the same.

Table 32

Cultural Content Knowledge

95\% Confidence Interval for

\begin{tabular}{|c|c|c|c|c|c|c|c|c|}
\hline & \multirow[b]{2}{*}{$\mathrm{N}$} & \multirow[b]{2}{*}{ Mean } & \multirow{2}{*}{$\begin{array}{c}\text { Std. } \\
\text { Deviation }\end{array}$} & \multirow{2}{*}{$\begin{array}{l}\text { Std. } \\
\text { Error }\end{array}$} & \multicolumn{2}{|c|}{ Mean } & \multirow[b]{2}{*}{ Min. } & \multirow[b]{2}{*}{ Max. } \\
\hline & & & & & Lower Bound & Upper Bound & & \\
\hline $\begin{array}{l}\text { No } \\
\text { ICStaskC }\end{array}$ & 43 & 3.686 & 1.5119 & .2306 & 3.221 & 4.151 & .0 & 5.0 \\
\hline ICStaskExp & 14 & 4.679 & .4644 & .1241 & 4.410 & 4.947 & 4.0 & 5.0 \\
\hline Total & 57 & 3.930 & 1.3965 & .1850 & 3.559 & 4.300 & .0 & 5.0 \\
\hline
\end{tabular}

Table 33

Levene test of homogeneity of variances (cultural content knowledge)

\begin{tabular}{cccc}
\hline Levene Statistic & df1 & df2 & Sig. \\
\hline 14.318 & 1 & 55 & .000 \\
\hline
\end{tabular}

Table 34

ANOVA (cultural content knowledge)

\begin{tabular}{lccccc}
\hline & Sum of Squares & df & Mean Square & F & Sig. \\
\hline Between Groups & 10.404 & 1 & 10.404 & 5.791 & .019 \\
Within Groups & 98.815 & 55 & 1.797 & & \\
Total & 109.219 & 56 & & & \\
\hline
\end{tabular}

To see if the residuals have approximately normal distribution, a histogram was constructed (see Figure 14). Since the histogram in Figure 14 reveals non-normality in the residuals, a non-parametric Mann-Whitney test was performed (see Table 35); a difference 
between groups was found for this test $(p$-value $=.026)$ and for ANOVA $(\mathrm{F}=5.791 \mathrm{Df}=1$ and the $p$-value $=0.019)$. Thus, with these results the author rejects the null hypothesis that states that there is no effect of the ICS task in L2's cultural content Knowledge, as measured in the final exam.

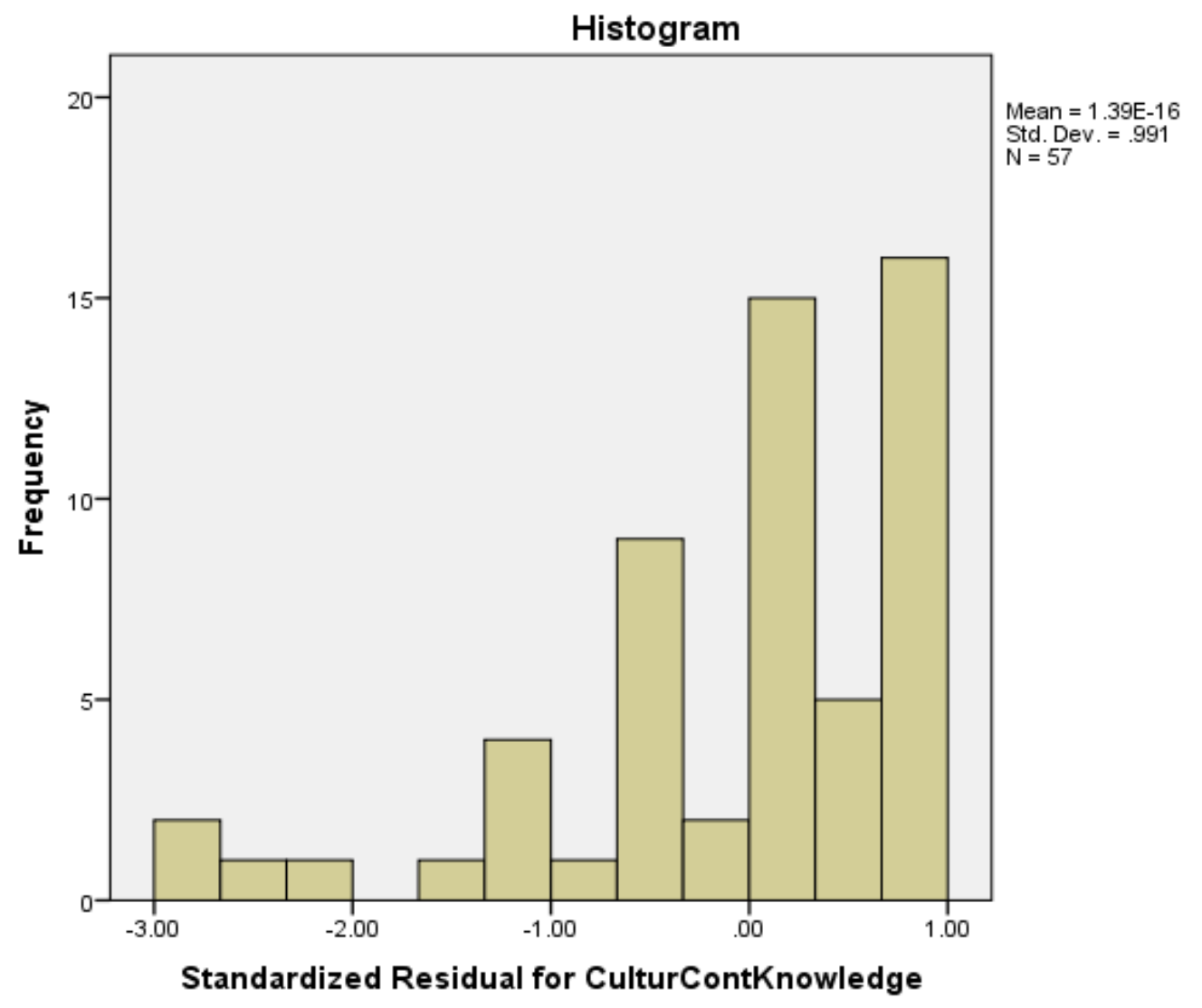

Figure 14. A histogram of the ANOVA residuals for cultural content knowledge. This histogram reveals non-normality in the residuals. 
Table 35

Mann Whitney Test ${ }^{\mathrm{a}}$

\begin{tabular}{lc}
\hline & \\
\hline Mann-Whitney U & CultContentKnowl \\
Wilcoxon W & 186.500 \\
Z & 1132.500 \\
Asymp. Sig. (2-tailed) & -2.227 \\
\hline
\end{tabular}

a. Grouping Variable: ICSTASK

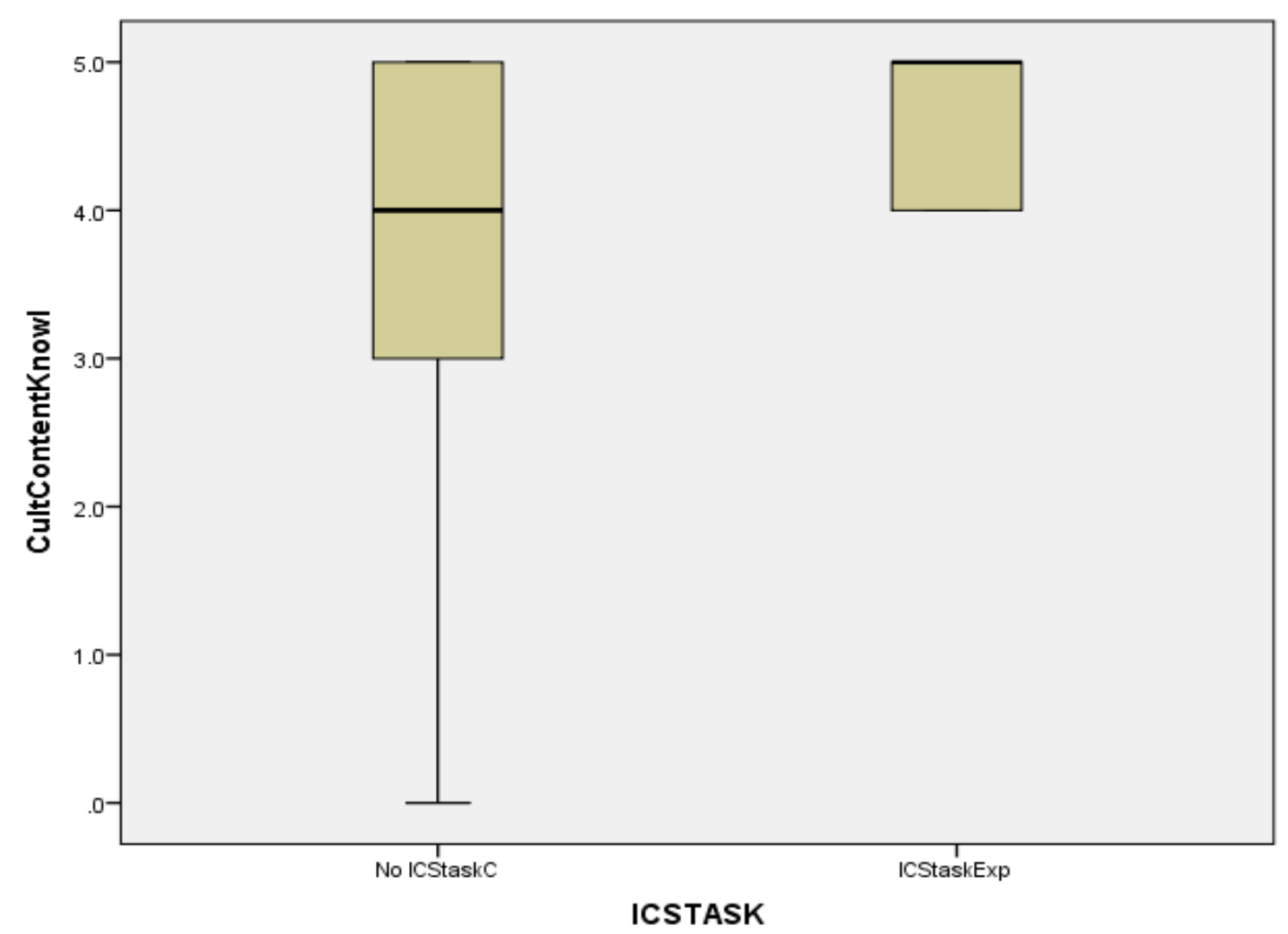

Figure 15. Distribution of the cultural content knowledge in the experimental and control groups.

\section{Research Question \# 2}


Does a set of two ICS tasks in the experimental group as opposed to the absence of these tasks in a control group result in a statistically significant difference in the cultural content knowledge as measured by the final exam?

\section{Discussion}

This statistical significance of the ICS task on the cultural content knowledge confirms the utility of the ICS task that facilitates the internalization of cultural content knowledge and is supported by research. Allen (ACTFL Convention, 2013) stated that culture has to be taught in the context and for the purpose of authentic language instruction and pointed out that the new culture standards call on learners to interact with "Cultural Competence and Understanding" because learners are now expected "to use the language to investigate, explain and reflect on these relationships" (p.163). Thus, the independent variable ICS task is tied to these criteria presented above because the participants investigated a cultural topic and then presented it orally to the class, to promote discussions and feedback from the rest of the class.

Furthermore, in reviewing the literature the author of this study found that current research expands on these concepts and puts forward the idea that measure of cultural content knowledge should be more through the experience and evidence of the student's investigation about the cultural topic, and less through the points earned on the final exam. For example, Schulz (2007) proposes a method of cultural assessment that integrates innovative procedures that are considered appropriate for students in beginning and intermediate college level foreign language courses. This method involves guidance and feedback, encouraging discussion, collaboration, revision, elaboration, and support of multiple sources of the cultural area. This way is said to encourage students' critical reflection and self-evaluation contrary to traditional 
methods of assessing culture such as multiple choice questions, and short answers questions, or essays tests that engage students in broad generalizations or stereotyping.

Shepard (2000) stated that assessment practices should change to be consistent with social constructivist pedagogy. Shepard drew a chronology of the history that comprises the traditional curricula and beliefs about assessment that are used to give grades to the students. Shepard also drew, an emergent constructivist paradigm in which the teacher's assessment of students is based on feedback from peers and self-assessment as a central part of the process of construction of knowledge (see Figure 16).

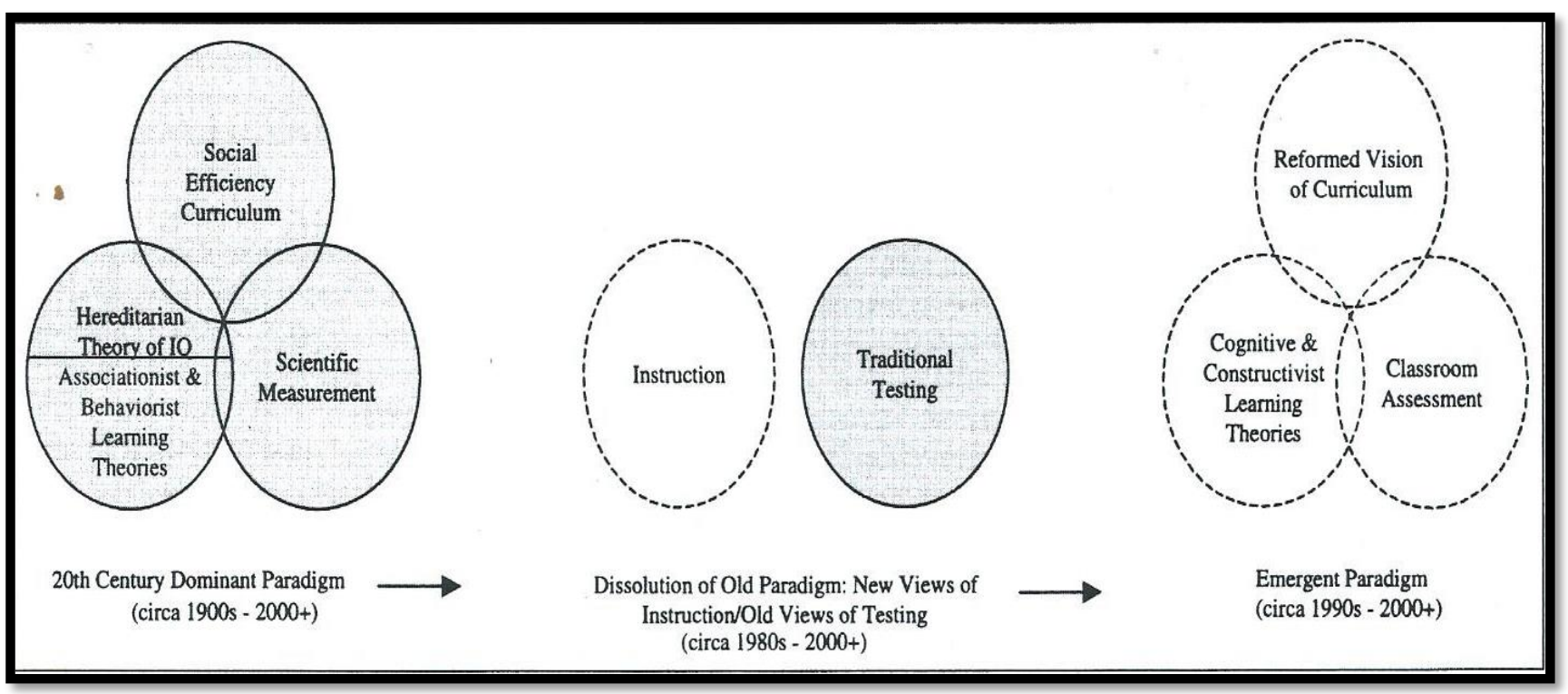

Figure 16. This is an historical overview that in essence illustrates some changes of the Curriculum, Learning Theories and Assessment. Shepard (2000).

There are a number of other important factors linked to the understanding of culture in the foreign language classroom. For example: 
1) Student's attitudes, which is generally defined as the positive or negative feelings that the students have toward the language, the language teacher, the language class, and the culture of people who speak the target language (Paige, Michael et al, 2000).

2) There a many students registered in foreign courses because they have to fulfill certain requirement in order to graduate rather than for any desire to learn about other language and culture (Paige, Michael et al, 2000).

3) The parent who has had an unfavorable experience with foreign language study is not likely to recommend it highly to his or her children, and those parents who speak a second language or were successful in languages classes "may be over zealous about foreign languages studies for their child to the point that it drives him away." The experience "of teachers, counselors, parents and community's attitude upon the learner is immeasurable." (Smith,1971, p. 84).

4) The importance that teachers and students recognize their own culture biases and negative attitudes. L2 student “gains an insider's view of another's culture while also deepening the understanding of his or her own culture" (Moeller \& Faltin, 2014, p. 2).

In summary, there is recognition of the limitations of current measurement theories; the field of educational assessment is looking for a new paradigm with a focus on support learning rather than on sorting and selecting students (Delandshere, 2002).

\section{Research question \# 3}

How, if at all, does the cultural content instruction differ across sections and what effects these potential differences in instruction have in this study? 
There are similar perspectives when examining the answer from the questionnaire presented to the Spanish instructors related to how cultural content knowledge is taught during class time. This similarity is probably due to the fact that the GTAs shared the same teaching approach established in the master program.

The first question on the questionnaire (see Appendix G) was about whether the instructors include cultural questions in the quizzes. All GTAs answered that not all the quizzes have cultural questions because quizzes are suggested to be short, with emphasis on vocabulary and grammar, and the cultural aspects are usually left to be asked in the exams and/or during class. The GTAs stated that unlike the quizzes, the listening and reading portions of the exam involve topics of culture and the specific aspects of culture are evaluated in the "section of culture" by formulating questions connected to cultural topics reviewed in class.

The culture content knowledge measured in this study was taken from those specific questions formulated in the cultural section of the final exam from: Argentine Gauchos, Spanish and Latin-American Life style and The Tango dance (see Appendix I Culture Section). Students answered the questions by writing a few lines, and questions were formulated in a way that enclosed some tips that stimulate the background knowledge or schemata. However, stimulus (drawings and pictures,) was not in the format, and students did not have enough material to grasp ideas to complete the answers. According to Lee and VanPatten (2003) when L2 students read a familiar or unfamiliar text, they activate their schemata or background knowledge it demonstrates, which may facilitate comprehension.

It was also affirmed by the Spanish GTAs in the questionnaire that unifying criteria for teaching cultural content is not difficult for Spanish instructors because they follow the book and 
share with each other the content to be included in the exams. There seems to be a consensus with regard to how cultural content should be taught, which was teaching culture as a process. As some instructors said:

"In class, depending on the topic, I like showing pictures, a video, or something more interactive and that encourages students to engage in a discussion or compare it to their own culture or other cultures with which they are familiar."

"We stress the importance of having a general idea about the topic and also the student's perception. For example, we normally ask our students to reflect on what they learnt or give their opinion."

The Spanish GTAs also believe that there are three relevant points involved in the teaching of culture: 1) the role played by the cultural background of the instructors. Some instructors recognized that they feel more comfortable when teaching the culture of their country. This affirmation is perfectly linked to a concept of self -awareness pointed out by Borghettis (2012) as an important component of the intercultural competence that focuses on how an individual reasons, acts, and recognizes his or her own limitation. This expressive situation also correlates with the statement that the classroom community is the best starting point for intercultural competence and involves not only cognitive processes, but also affective processes.

2) Time to cover all cultural content knowledge because students are assessed not only on grammar and vocabulary, but also on culture. It is possible that the GTAs face in the classrooms the same question found in a qualitative study conducted by Cabrera (2015) that involved revision of material used in foreign language classrooms and interviews of foreign languages teachers. One of the aspect presented by Cabrera was that "through interaction between teachers 
about material for teaching culture L2 construct cultural knowledge." Cabrera revealed that teachers face in the classroom a variety of aspects: 1) how to balance the teaching of culture and providing instruction of the language, 2) what aspects of the culture should be the focus, and 3) when is the best age to introduce the teaching of culture (p. 86).

Another manifestation of the GTAs concerns was that part of the success of instruction depends on the classroom's technological support. Technological supports are important because they are tools that help student internalize the language and culture. There is much that students can learn from music, videos, news, movies, commercials and cartoons. Technology is defined as the access to a computer and projector on which to play the aforementioned media. Today, most of the classrooms count upon technology of tools to present videos, music, etc. If the classroom lacks technological support, the GTAs have to use readings and discussions, and bring materials to the classroom to engage the students in the cultural topic. However, these statements from the GTAs show that even though there are limitations, they encourage their students' progress toward cultural competence.

GTAs agreed that to avoid Spanish students struggling with cultural content in their classroom, the input of culture should be meaningful and related to student's culture. When reviewing the literature, the author of this study realized that when teaching culture, it is imperative that work should be related to some concepts of theoretical models of intercultural communicative competency (ICC). Even though individual features compose the models, the general structure of ICC is summarized as knowledge, skill, and attitude (Moeller \& Nugent, 2014). 
In summary, culture content knowledge is a concern in foreign languages classrooms regarding to the content, the way to teach and the way to assess it. As the questionnaire reveals there was not large differences among the instructors' approach to teach culture across sections. 


\section{Chapter V}

This chapter presents conclusions, implications and recommendations based on the procedure and results of this study completed "in situ" in six sections of university level intermediate Spanish. This study is in line with previous works, and attempts to contribute to the understanding of both the complex process of oral production and the weakness of cultural content knowledge in a second language that are encountered in the language classrooms.

\section{Summary}

This quantitative study lasted 6 weeks. The participants were 57 university students, 14 students for the experimental group and 37 students for the control group. The first weeks of the study were used to explain the procedure of the task to the instructors and then students were encouraged by the instructor to inquire about any Hispanic cultural topic and to present it orally to the class. These tasks called ICS (individual cultural speeches), took place twice during class time in three sections of intermediate Spanish students. Two post-tests were applied to measure accuracy and cultural content knowledge of the experimental and control groups. The post-test for accuracy was a poster project presentation that the class had to present orally at the end of the semester. The post-test for cultural content knowledge consisted of the points earned by the students in the culture section of the final exam. The statistical analysis revealed that global accuracy, verb accuracy and cultural content knowledge were statically significant; however, the analysis showed no statistical significance in terms of article accuracy. 


\section{Conclusions}

These results show that by using level-appropriate content and implementing an oral task during class time, students improve accuracy and cultural content knowledge in Spanish, without interfering with the regular lesson plan of the class.

The results of this study are consistent with previous research. The two ICS tasks, which followed the same procedure but different topics, were prepared by the students with enough time, and guidance from the instructor and presented orally to the class, cause different effects on CAF. In terms of accuracy (which is the element of CAF that was measured in this investigation), this study shows that global accuracy and verb accuracy, measured during the poster project presentations, significantly improve as a result of the ICS task. The effect on article accuracy during the poster project presentation was not significant, due to the difficult nature of the grammatical structure, which is not typically acquired until more advanced levels. However, it is not an impediment to affirming the need to create strategies for output, like the ICS task, that represent an effective intervention to promote focus on form and, subsequently, the avoidance of persistent errors and fossilization in oral production.

On the other hand, the dependent variable cultural content knowledge, as measured by the final exam, had statistical significance in this study. This result is linked to the procedure of the ICS task, which involves cultural inquiry, permanent exchange with the instructor, and sharing that knowledge with the rest of the class through an oral presentation. This process enabled the language learners to internalize culture constructs from Hispanic culture and discern the relevant different from their own culture. 


\section{Implications and Recommendations}

The foundational idea of modern CLT is that the model of instruction in the foreign language classroom cannot involve mere instruction-response-evaluation while ignoring those tasks that encourage the learner to communicate. Therefore, as a communicative task, the pedagogical implications of the ICS are, first, base tasks on student centered learning, just as the ICS task connects L2 students with real world information discovered by them. Second, develop tasks that require L2 students to participate in a meaningful mode of learning and communication in the target language.

Another factor to consider is student attitude. Students have many different positive or negative feelings toward language learning, so researchers have described various productive ways to teach language in order to engage students in a positive fashion. One current tendency, compatible with constructivist pedagogy, is to have learners investigate, explain and reflect about culture in the classroom, as in the ICS task. In that way, L2 learners interact more with the culture, and assessment can be based more on feedback from peers and self-assessment than grades assigned by the instructor.

The recommendation to foreign language instructors, is to evaluate constantly not only how language is taught, but also how language is learned, thus it is imperative to interpret and reproduce the meaning of SLA theories and approaches in order to choose the best strategies that focus on the acquisition and production of the target language. I would recommend for further studies to investigate pedagogic tasks that involve pre-planning, culture inquiry, oral production and public presentation in the target language, due to the encouraging effects on accuracy and cultural content knowledge demonstrated in this study, especially as both are necessary to 
acquire a second language. Since this study was applied to students of Spanish, I would recommend these strategies be applied to students of other languages as well. 


\section{References}

Ahmadian, M., \& Tavakoli, M. (2010). The effect of simultaneous use of careful online planning and task repetition on accuracy complexity, and fluency in EFL learners' oral production. Language Teaching Research, 15(1), 35-59.

Allen, W. (2009). In search of relevance: The role of the Standards in the undergraduate foreign language curriculum. SELECTED WORKS. Retrieved from http://works.bepress.com/heatherwillisallen/13

Allen, W. (2013). Developing Cultural Proficiency. ACTFL conference. Orlando.

American Council on the Teaching of Foreign Language. (2006). Standards for Foreign Languages learning in the $21^{\text {st }}$ century. National standards in Foreign Languages education project. 518 p.

Amores, M., Suárez-García, J. L., \& A. Wendel. (2011). Experiencing Spanish. Mac Graw Hill Education.

Barrette, C., and Salaberry R. (2011). Developing speaking competence through focused activities. ACTFL convention. Denver.

Borghetti, C. (2012). Pursuing intercultural and communicative goals in the foreign language classroom: clues from selected models of intercultural competence. In Translation, Technology and Autonomy in Language Teaching and Learning, ed. P. Alderete-Díez, L. Incalcaterra McLoughlin, L. Ní Dhonnchadha and D. Ní Uigín, 333-59. Bern, Switzerland: Peter Lang.

Brown HD. (1976). Discussion of "Systematicity and Stability/Instability in Interlanguage Systems." In: HD Brown (ed.), Papers in second language acquisition (Language learning special issue $\mathrm{N}^{\circ} 4$, Proceedings of the sixth annual conference on applied linguistics, Universidad of Michigan, January 30-February 1, 1975) 135-140

Byrd, D. R., Cummings Hlas, A., Watzke, J., \& Montes Valencia, M. F. (2011). An examination of culture knowledge: A study of L2 teachers' and teacher educators' beliefs and practices. Foreign Language Annals, 44(1), 4-39.

Cabrera C., M. (2015). Teaching Culture in Foreign Language Classrooms of International Baccalaureate Schools (Doctoral dissertation, Walden University).

Canale, M., \& Swain, M. (1980). Theoretical bases of communicative approaches to second language teaching and testing. Applied linguistics, 1 (1), 1-47.

Cramer, D. (1998). Fundamental statistics for social research: step-by-step calculations and computer techniques using SPSS for Windows. Psychology Press.

Cronk, B. (2008). How to use SPSS. A step-by-step gude to analysis and interpretation. Pyrczak Publishing. ( $5^{\text {th }}$ ed.). Glendale, CA, USA.

Delandshere, G. (2002). Assessment as inquiry. Teachers College Record, 104(7), 1461-1484. 
Demirezen, M. (1998). Behaviorist Theory and Language Learning. Retrieved 2/25/2015 from http://www.efdergi.hacettepe.edu.tr/19883MEHMETDEMC4B0REZEN.pdf.

Doughty, C., \& Williams, J. (1998). Focus on form in classroom SLA. Cambridge 301 p.

Ellis, R. (1987). Interlanguage variability in narrative discourse: Style shifting in the use of the past tense. Studies in second language acquisition, 9(1), 1-19.

Ellis, R. (2005). Planning and task-based performance: Theory and research. Planning and task performance in a second language, 11, 3-34.

Ellis, R. (2009). The Differntial Effects of Three Types of Task Planning on the Fluency,Complexity, and Accuracy in L2 Oral Production. Applied Linguistics, 474-509.

Fang, X. (2010). The Role of Input and Interaction in Second Language Acquisition. Cross-cultural Communication 6 (1), 11-17

Fernandes, S. (1995). Errores de desarrollo y errores fosilizables en el aprendizaje del E/LE Tratamiento didactico. ASELE.

Fernandes-Garcia, S. (2012). El español como segunda lengua en anglohablantes: La enseñanza de la gramatica y la pronunciacion. Tesis de Master en español como lengua extranjera. Universidad de Oviedo. $40 \mathrm{p}$.

Gass, S. M., \& Mackey, A. (2007). Input, interaction, and output in second language acquisition. In B. VanPatten \& J. Williams (Eds.), Theories in second language acquisition: An introduction (pp. 175-199). Mahwah, NJ: Lawrence Erlbaum.

Gharbavi, A., \& Mousavi, S. A. (2012). Do language proficiency levels correspond to language learning strategy adoption? English Language Teaching, 5(7), 110.

Griffiths, C., \& Parr, J. (2001, July). Language-learning strategies: theory and perception. ELT Journal, $55(3), 247-254$.

Gutierrez-Araus, M. L. (1991). Sobre Ser/Estar en español. ASELE. Acta III.

Hall, E. (1976). Beyond Culture. Anchor books editions. New York.

Han, Z. (2004). Fosilizaciónin adult second language acquisition. Clevedon, UK: Multilenguge matters.

Housen, A., \& Kuiken, F. (2009). Complexity, accuracy, and fluency in second language acquisition. Applied linguistics, 30(4), 461-473.

Isabelli-García, C. (2010). Acquisition of Spanish gender agreement in two learning contexts: Study abroad and at home. Foreign Language Annals, 43(2), 289-303.

Koike, D. A., \& Klee, C. (2013). Lingüística aplicada: Adquisición del español como segunda lengua. New York: Wiley. 
Kormos, J. (2006). Speech production and second language learning. Mahwah, NJ: Lawrence ErlbaumAssociates.

Kormos, J. (2011). Speech production and the Cognition Hypothesis. Second language task complexity: Researching the Cognition Hypothesis of language learning and performance, 39-59.

Kramsch, C. (1995). The cultural component of language teaching. Language, culture and curriculum, 8(2), 83-92.

Kramsch, C. (2014). Language and culture. Aila Review, 27(1), 30-55.

Krashen, S. D. (1982). Principles and practice in second language adquisition. Learning, 46(2), 327-69.

Lee, L. (2012). Engaging Study Abroad Students in Intercultural Learning through Blogging and Ethnographic Interview. Foreign Language Annals, 45(1), 7-21.

Lee, L., \& Van Patten, B. (2003). Making Communicative Language Happpen. McGrawHill. New York.

Levelt, W. J. (1995). The ability to speak: From intentions to spoken words. European Review, 3(1), 1323.

Lindseth, M. (2016). The Effects of Form-Focused Instruction on the Acquisition of Subject-Verb Inversion in German. Foreign Language Annals, 49(1), 10-22.

Long, M. H. (1991). Focus on form: A design feature in language teaching methodology. Foreign language research in cross-cultural perspective, 2(1), 39-52.

Master, P. A. (1987). A cross-linguistic interlanguage analysis of the acquisition of the English article system. PhD dissertation. University of California. LA.

Mavrou, I. (2013). Precisión lingüística y complejidad sintáctica: ¿hasta qué punto compiten entre sí por los recursos limitados del aprendiz? Revista Nebrija de Lingüística Aplicada a la Enseñanza de Lenguas, (14), 75-91.

Modern Language Association. MLA Ad Hoc Committee on Foreign Languages. (2007). Foreign Languages and Higher Education: New Structures for a Changed World. Profession, 234-245. https://doi.org/10.1632/prof.2007.2007.1.234.

Moeller, A. and Faltin, S. (2014). A pragmatist perspective on building intercultural communicative competency: from theory to classroom practice. Foreign Language Annals 47 (4),

Moeller, A. K. and Nugent, K. (2014) "Building intercultural competence in the language classroom". Faculty Publications: Department of Teaching, Learning and Teacher Education. 161. Retrieved from: http://digitalcommons.unl.edu/teachlearnfacpub/161.

Nieto, S. (2010). Language Culture and Teaching: Critical perspectives. (2 ${ }^{\text {nd }}$ ed.). New York.

Nunan, D. (1988). Syllabus Design. Language Teaching: A scheme for teacher education. (C. Candlin and H. Widdowson, Ed.). Oxford University Press. Oxford. 171 p. 
Omaggio - Hadley, A. C. (2001). Teaching language in context, (3rd ed). Heinle and Heinle. Boston. $512 \mathrm{p}$.

Ortega, L. (2009). Studying writing across EFL contexts: Looking back and moving forward. Writing in foreign language contexts: Learning, teaching, and research. (Rosa Manchon ed.). 232-25

Ortega, L. (1999). Planning and focus on form in L2 oral performance. Studies in second language acquisition, 21(1), 109-148.

Paige, R. M., Jorstad, H., Siaya, S., Klein, F., \& Colby, J. (2000). Culture learning in language education: A review of the literature. Unpublished manuscript, Center for Advanced Research on Language Acquisition, University of Minnesota. Retrieved February 25, 2016, from http://carla.acad.umn.edu/IS-litreview/litreview.doc

Palloti, G. (2009). Defining, refining and differentiating constructs. Applied Linguistics. 30(4), 590-601.

Payne, J. S., \& Whitney, P. J. (2002). Developing L2 oral proficiency through synchronous CMC: Output, working memory, and interlanguage development. Calico Journal, 20(1), 7-32.

Penstone, J. (2011). Interculturalism matters. http: Interculturalism blogspot.com/2011/03/iceberg Model of culture.html. Retrieved August 12, 2016.

Phillips, J. (2015). Use Language to Explore Culture: Preparing Educator to Guide Learners. $A C T F L$ pre-conference workshop. San Diego, CA.

Rahimpour, M., \& Fatemeh, H. (2006). Interactional Feedback, Strategic Planning \& Interlanguage Variation. Research on Foreign Languages, 49(200),48-68.

Rahimpour, M., \& Hazar, F. (2007). Topic familiarity effect on accuracy, complexity, and fluency of L2 oral output. The Journal of Asia TEFL, 4(4), 191-211.

Reilly, T. (1988). Approaches to foreign language syllabus design. [Electronic version]. In Krahnke, K., Approaches to syllabus design foreign language teaching. New York: Prentice-Hall/Regents. (ERIC Document Accession No: ED 295460).

Richards, J. and Schmidt, R. (2013). Longman Dictionary of Language Teaching and Applied Linguistics. Longman Publishing Group. 595 p.

Richards J. (2003). Curriculum development in language teaching. Cambridge Language Education.

Robinson, P. (2009). Syllabus Design. In: Long, M. H., \& Doughty, C. J. (Eds.). (2011). The handbook of language teaching (Vol. 63) Chapter 17. John Wiley \& Sons.

Robinson, P. (2007). Task complexity, theory of mind, and intentional reasoning: Effects on L2 speech production, interaction, uptake and perceptions of task difficulty. Iral-international Review of Applied Linguistics in Language Teaching, 45 (3), 193-213

Robinson, P. (2001) Cognition and Second Language Instruction. Cambridge University Press.464 p. Cambridge. 
Robinson, P., \& Gilabert, R. (2007). Task complexity, the cognitive hypothesis and second language learning and performance. International Review of Applied Linguistics in Language Teaching, 45(3), 161-176.

Salaberry, R. and Lopez-Ortega, N. (1998). Accurate L2 production across language tasks: focus on form, focus on meaning and communicative control. Modern Language Journal, 82, 114-157.

Salaberry, R. (2003). Tense Aspect in Verbal Morphology. Hispania, 86(3), 559-573.

Schulz, R. A. (2007). The challenge of assessing cultural understanding in the context of foreign language instruction. Foreign Language Annals, 40(1), 9-26.

Schütz, R. (2005). Stephen Krashen's theory of second language acquisition. Assimilação Natural -- $o$ Construtivismo no Ensino de Línguas. Retrieved June 25, 2015, from http://www.sk.com.br/skkrash.html.

Shepard, L. (2000). The role of assessment in a learning culture. Educational Researcher 29(7), 4-14.

Skehan (1998). A Cognitive Approach to Language Learning. Oxford University Press, Oxford.

Skehan, P. (2009). Modeling Second Language Performance: Integrating Complexity, Accuracy, Fluency, and Lexis. Applied Linguistics, 30(4), 510-532.

Skehan, P. (2014). Limited attentional capacity, second language performance, and task-based pedagogy. In Processing perspectives on task performance. (Skehan, P. ed). Chapter 8, 211-260.

Skehan, P., \& Foster, P. (1997). Task type and task processing conditions as an influence on foreign language performance. Language Teaching Research 1(3), 185-211

Skehan, P., \& Foster, P. (1999). The Influence of Task Structure and Processing Conditions on Narrative Retellings. Language

Smith, A. (1971). The Importance of Attitude in Foreign Language Learning. Modern Language Journal, 55(2), 82-88

Stoller, F. (2002). Project work: A means to promote language and content. In: Methodology in language teaching: An anthology of current practice. J Richards \& W Renandya. (Eds). Chapter $10,107-119$.

Swain, M. (1985). Communicative competence: Some roles of comprehensible input and comprehensible output in its development. Input in second language acquisition, 15, 165-179.

Swain, M. (1993). The Ouput Hypothesis: Just Speaking and writing Aren't Enough. The Canadian Modern Language Review.

Swain, M. (2000). The output hypothesis and beyond: Mediating acquisition through collaborative dialogue. Sociocultural theory and second language learning, 97, 114.

Tarone, E. (2006). Interlanguage. 4, 747-752. Retrieved February 25, 2016, from socling.genlingnw.ru/files/ya/interlanguage\%20Tarone.PDF. 
VanPatten, B. and Williams, J. (2007). Theories in second language acquisition: An introduction. LEA eds. Mahwah, New jersey.

Wang, Q., \& Castro, C. D. (2010). Classroom Interaction and Language Output. English language teaching, 3(2), 175-186.

Wang, Z. (2014). On-line time pressure manipulations (pp. 27-62). Amsterdam: John Benjamins.

Williams, J. (1992). Planning, discourse marking, and the comprehensibility of international teaching assistants. TESOL Quarterly, 26(4), 693-711.

Williams, J. (1995). Focus on form in communicative language teaching: Research findings and the classroom teacher. TESOL journal, 4(4), 12-16.

Zhang, S. (2009). The Role of Input, Interaction and Output in the Development of Oral Fluency. English Language Teaching, 2(4), 91-100. 


\section{Appendix A}

Poster Project as presented in the syllabus Intermediate Spanish 2 (MWF) Spring 2014

POSTER PROJECT (10\%): The Poster Project will consist of the development of a static visual display, or a PowerPoint presentation, based on a cultural aspect related to the themes in the textbook Experience Spanish or themes suggested by the instructor. The posters will be prepared in groups of three and will be presented in the classroom. Students in the class will select two posters that they consider to be the best in terms of effectiveness and creativity. The authors will receive 2 points that will be added to their average grade for the course. See attached for grading criteria and guidelines for preparation of poster projects.

\section{GUIDELINES FOR POSTER PROJECTS}

1. Poster projects will consist of the development of a static visual display, or a PowerPoint presentation, based on a cultural aspect related to the themes in the textbook Experience Spanish or themes suggested by the instructor.

2. The posters will be prepared in groups of three and will be presented in the classroom on the date indicated in the syllabus.

3. Before selecting a topic, each group should do some research to determine the availability and accessibility of proper information and visual support.

4. All groups are required to prepare an outline of the content of the poster and make an appointment with their instructor to discuss their plan before starting working on it. Students have to bring the outline to the appointment.

5. Posters should contain excellent visual support (photographs, etc.), written explanations of the content, which should be expressed with students' own words, and the bibliographical sources consulted.

6. Each group should prepare a short activity based on the content of the poster to be done by their classmates on the day the poster will be displayed in class. 
7. Groups should be prepared and able to answer questions that other students may have and expand on the content of their poster.

8. Students will vote individually to select the best two posters in the classroom in terms of effectiveness and creativity. The authors will receive 2 points of extra credit that will be added to their average grade for the course.

9. Your instructor will provide you with useful web pages for doing research in Spanish on Internet.

\section{GRADING CRITERIA For Poster Project}

\begin{tabular}{|c|c|c|c|c|c|c|}
\hline \multicolumn{7}{|c|}{ Poor } \\
\hline Quality and quantity of information & 1 & 2 & 3 & 4 & 5 & 6 \\
\hline Organization and visual appeal & 1 & 2 & 3 & 4 & 5 & 6 \\
\hline Creativity & 1 & 2 & 3 & 4 & 5 & \\
\hline Accuracy of language & 1 & 2 & 3 & 4 & 5 & 6 \\
\hline
\end{tabular}

Total $\quad / 25$

Note. This Syllabus was taken from a Basic Spanish Program. Some non relevant aspect where not presented. 


\section{Appendix B}

\section{Expresiones artísticas}

1930 siones artisticas, Notes: - Varo studied at the Acaderny in Madrid. After living in Paris from 1930 to 1932, she settled in Barcelona, where she met the French surrealist poet Beniamin Peret At the beginning of the Spanish Civil War, the couple moved to Paris, where they married in 1937.

of the moris Vare exhibited works in the lint

of the most influential st

C Remedios Varo most influential surrealist joumals, Minotaure

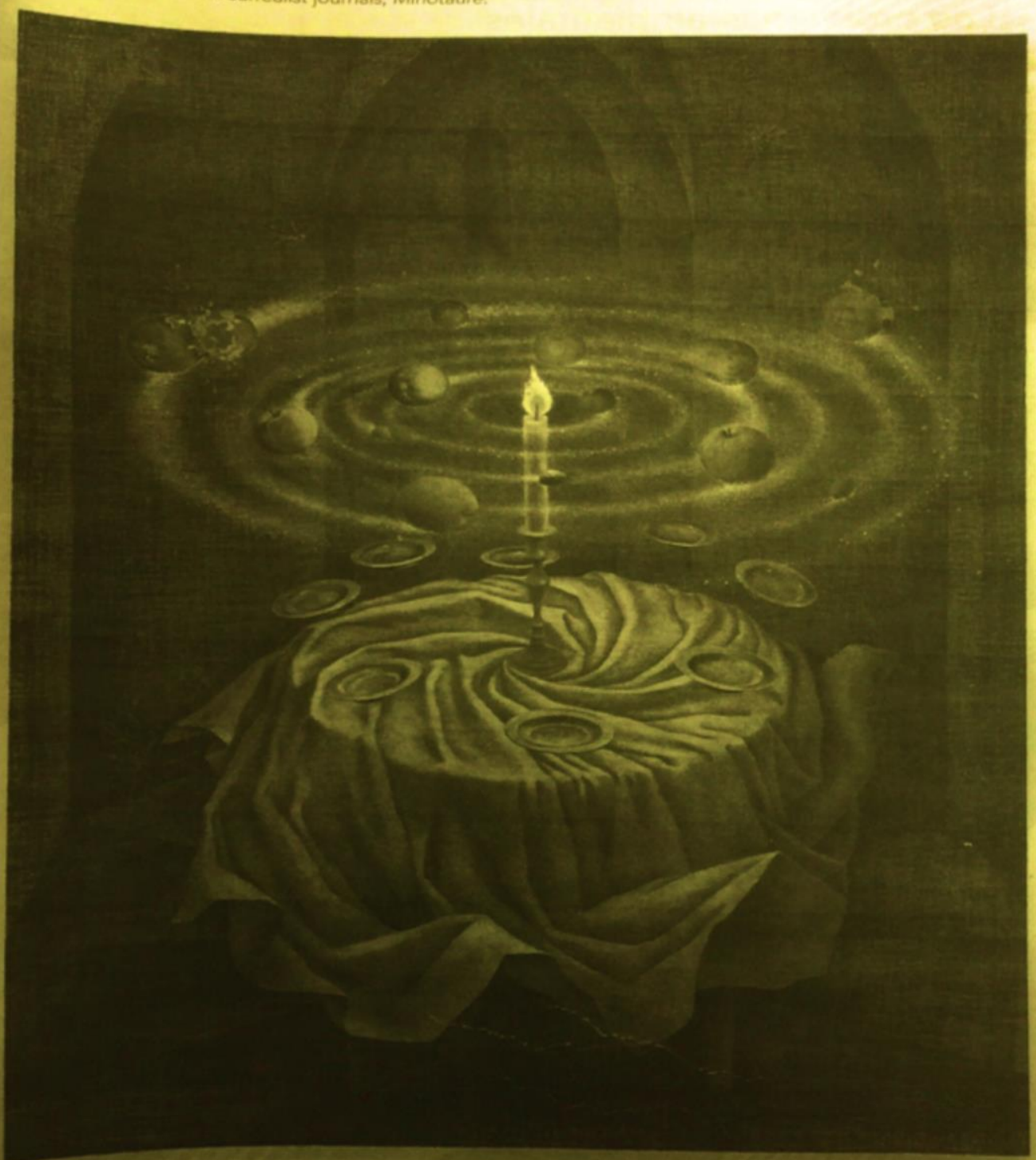

Remedios Varo (1908-1963), nacida en Gerona, España, formó parte, junto con Salvador Dalí, del grupo de pintores surrealistas españoles de los años 20. Debido a la Guerra Civil española en 1936, y luego la Segunda Guerra Mundial, Varo se exilió primero en París y más tarde en México, donde se involucróa en el movimiento surrealista mexicano.

Muchas de las obras de Varo reflejan sus huidas ${ }^{\mathrm{b}}$ de conflictos y casi siempre incluyen figuras humanas que representan la fuga ${ }^{c}$ de una prisión figurativa. En Naturaleza muerta resucitando, su última obra, no son seres humanos los que se escapan, sino objetos: una mesa, ocho platos, fruta y una vela. ${ }^{d}$ Los objetos sintetizan la vida de la artista, volando como pequeños planetas alrededor de la vela en preparación para la huida por una ventana peq́ueña.

"se... she became imvolved "escapes "escape "candle 


\section{Appendix B1}

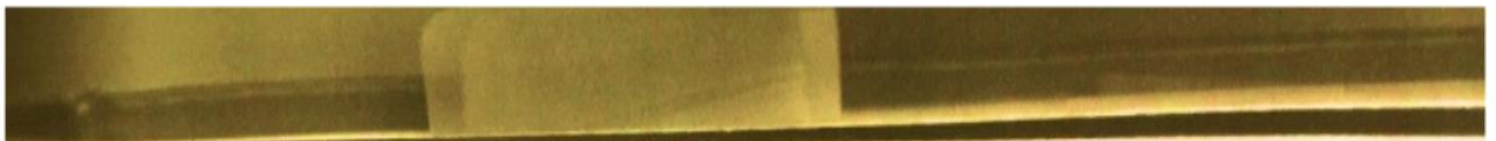

Nota cultural

LA MUJER Y EL MERCADO LABORAL

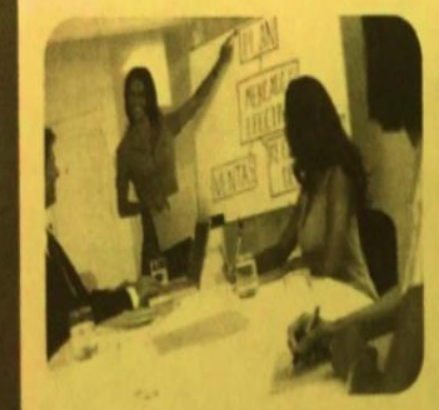

En Latinoamérica, la mujer siempre ha sido importante para el mantenimiento de la economía familiar. Además de cuidar de la casa y de los hijos, la mujer desarrolla otras actividades laborales informales que ayudan a la principal fuente de ingresos, normalmente el hombre. Adicionalmente, en 1990, treinta y cuatro de cada cien mujeres trabajaban formalmente, mientras que en 2008, su tasa de participación laboral era del $52 \%$. Además, el nivel educativo de las mujeres es superior al de los hombres. Las cifras son aún mayores en los paises del Cono Sur, especialmente en Argentina y Chile, cuyo desarrollo económico y social es superior a la mediab en Latinoamérica.

Aunque hay más trabajo para las mujeres y están mejor preparadas que antes, todavía continúan los problemas en la calidad de su inserción laboral.' Por ejemplo, una mujer debe tener más años de estudio que un hombre para recibir un salario similar. Las mujeres siguen dominando en los sectores peores pagados y su presencia es mayoritariamente superior en el área de servicios y en el servicio doméstico, que absorbe el $17 \%$ del empleo femenino. Otro ejemplo de discriminación se ve en las posibilidades de promoción para la mujer en su lugar de trabajo, significativamente menores que las del hombre.

"rate 'mean 'inserción... job placement

PREGUNTAS En parejas, contesten las preguntas y después, compartan sus ideas con la clase.

1. En su opinión, ¿qué es un trabajo formal y qué es un trabajo informal?

2. ¿Qué problemas enfrenta la mujer latinoamericana en el mundo laboral?

3. ¿Cuáles son los trabajos realizados principalmente por las mujeres?

4. ¿Existe una situación similar en este pais? Expliquen. 
Appendix C

The ICS task Procedure

1) The ICS task will be applied during five weeks.

2) Students will schedule the two tasks, and the instructor of this study will give them the procedure for presenting the ICS task (See schedule).

3) Each student has to decide what topic from the textbook will be investigated and has to be prepared for the oral presentation.

4) The time for planning ICS tasks is between 5-7 days. During the task planning time, it is suggested that the students ask the instructor any questions related to the topic of the presentation, Spanish grammar, or vocabulary to be used.

5) Students may supplement the presentation with power points or posters and will arrange individual cultural presentations of no less than five sentences. However, students may not read

6) The time limit per presentation will be 5 or 7 minutes. After the presentation, the instructor can formulate open-ended questions so that the rest of the class can participate in the activity.

7) The corrective feedback will be given to the L2 students by the instructor after the presentation during the office hours. Students are not permitted to present the ICS tasks in the office of the instructor or investigator.

Note. This procedure was given to every participant to prepare the ICS task. 
Appendix D

204 Spanish course Schedule and Characteristics. Spring 2014

\begin{tabular}{|l|l|l|l|}
\hline Course Schedule & \# Students per Section & Day of the Week & Duration \\
\hline 1) 8:30-9:20 a.m. & 25 & M-W-F & 50 minutes \\
\hline 2) 8:30-9:20 a.m. & 26 & M-W-F & 50 minutes \\
\hline 3) 9:30-10:20 a.m. & 23 & M-W-F & 50 minutes \\
\hline 4) 9:30-10:20 p.m. & 26 & M-W-F & 50 minutes \\
\hline 5) 12:30-1:20 p.m. & 26 & M-W-F & 50 minutes \\
\hline 6) 1:30-2:20 p.m. & 26 & M-W-F & 50 minutes \\
\hline 7) 1:30-2:20 p.m. & 26 & M-W-F & 50 minutes \\
\hline 8) 1:30-2:20 p.m. & 26 & M-W-F & 50 minutes \\
\hline 9) 2:30- 3:20 p.m. & 26 & M-W-F & 50 minutes \\
\hline 10) 2:30- 3:20 p.m. & 26 & M-W-F & 50 minutes \\
\hline Total of Students & 256 & & \\
\hline
\end{tabular}

$\mathrm{N}=256 \mathrm{~L} 2 \mathrm{~s}$

Note: 256 students registered in 10 sections schedule Mondays/Wednesdays /Fridays between 8:30 a.m. and 3:20 p.m. will participate in this study. Experimental and control groups will be randomly selected from this sections. 94 students registered on Tuesday /Thursday sections at night time do not participate in this study. 


\section{Appendix E}

For the Instructor/ Scheduling the ICS task

\begin{tabular}{|l|l|l|}
\hline Student/\# task & Topic & Date \\
\hline 1 & & \\
\hline 2 & & \\
\hline 1 & & \\
\hline 2 & & \\
\hline 1 & & \\
\hline 2 & & \\
\hline 1 & & \\
\hline 2 & & \\
\hline 1 & & \\
\hline 2 & & \\
\hline 1 & & \\
\hline 2 & & \\
\hline 1 & & \\
\hline & & \\
\hline & & \\
\hline & & \\
\hline & & \\
\hline & & \\
\hline
\end{tabular}


Appendix F Calendar for the ICS task

\begin{tabular}{|llc}
\hline March17 & Capítulo 14: Nosotros y el mundo natural & \\
March19 & Capítulo 14: Nosotros y el mundo natural & Meeting with GTA s \\
March21 & Capítulo 14: Nosotros y el mundo natural & Semana 1 \\
March 24 & Capítulo 14: Nosotros y el mundo natural & \\
March 26 & Capítulo 14: Nosotros y el mundo natural & Semana 2 \\
& $*$ Palabra escrita: A finalizar & \\
Total ICS tasks presented__ & \\
March 28 EXAM 2: Capítulo 14 &
\end{tabular}

March $31 \quad$ Capítulo 15: La vida moderna

April 2 Capítulo 15: La vida moderna

April $4 \quad$ Capítulo 15: La vida moderna

Semana 3

Total ICS tasks presented_

April 7 Capítulo 15: La vida moderna

* Palabra escrita: A comenzar

April 9 Capítulo 15: La vida moderna

Semana 4

April 11 Capítulo 15: La vida moderna

Total ICS tasks presented_

April 14 Capítulo 15: La vida moderna

April 16 Capítulo 15: La vida moderna

Semana 5

Total ICS tasks presented

April 18 ; Friday Before Easter Recess-NO CLASS

21 April Capítulo 15: La vida moderna

* Palabra escrita: A finalizar

Total ICS tasks presented

Semana 6

April 23 POSTER PRESENTATION

April 25 POSTER PRESENTATION

Important: please video record the posters

Note .Source: 204 Syllabus WVU/Spring 2014. 


\section{Appendix G}

Questionnaire gave to instructors who participate in the study

1) Do you include culture content knowledge in your quizzes? Please explain why/why not.

2) Do the exams include culture content knowledge being taught in 204 classes? Please explain.

3) Do you think instructors of 204 courses have unified criteria about what topics to cover on the cultural content knowledge objectives?

4) What strategy do you use for teaching culture content knowledge?

5) Do you think that 204 students struggle with content culture knowledge? If your answer is yes, would you solve it? How?

6) Have you a concern/worry about the cultural content knowledge instruction in 204 level? Please explain.

7) Does the background knowledge of instructors play a role in the cultural content knowledge in the instruction of Spanish 204 class? Please explain.

Note: These questions are related to the research question \# 3 . 


\section{Appendix H}

Demographic Information Instrument

Section Time:

\begin{tabular}{|c|c|c|c|c|c|c|c|}
\hline Students & Age & Sex & Place Origin & Freshman & Sophomore & Junior & Senior \\
\hline \multicolumn{8}{|l|}{1} \\
\hline \multicolumn{8}{|l|}{2} \\
\hline \multicolumn{8}{|l|}{3} \\
\hline \multicolumn{8}{|l|}{4} \\
\hline \multicolumn{8}{|l|}{5} \\
\hline \multicolumn{8}{|l|}{6} \\
\hline \multicolumn{8}{|l|}{7} \\
\hline \multicolumn{8}{|l|}{8} \\
\hline \multicolumn{8}{|l|}{9} \\
\hline \multicolumn{8}{|l|}{10} \\
\hline \multicolumn{8}{|l|}{11} \\
\hline \multicolumn{8}{|l|}{12} \\
\hline \multicolumn{8}{|l|}{13} \\
\hline \multicolumn{8}{|l|}{14} \\
\hline \multicolumn{8}{|l|}{15} \\
\hline \multicolumn{8}{|l|}{16} \\
\hline \multicolumn{8}{|l|}{17} \\
\hline \multicolumn{8}{|l|}{18} \\
\hline \multicolumn{8}{|l|}{19} \\
\hline \multicolumn{8}{|l|}{20} \\
\hline \multicolumn{8}{|l|}{21} \\
\hline \multicolumn{8}{|l|}{22} \\
\hline \multicolumn{8}{|l|}{23} \\
\hline \multicolumn{8}{|l|}{24} \\
\hline \multicolumn{8}{|l|}{25} \\
\hline \multicolumn{8}{|l|}{26} \\
\hline \multicolumn{8}{|l|}{27} \\
\hline 28 & & & & & & & \\
\hline
\end{tabular}




\section{Appendix I}

Final Exam Spanish 204 - Spring 2014

\section{Vocabulary Section}

A. Palabra intrusa. Encuentre la palabra que no corresponde en la serie. (10 puntos)

\begin{tabular}{|l|l|l|l|l|}
\hline 1. & a. la amistad & b. el noviazgo & c. el amor & d. la separación \\
\hline 2. & a. el corazón & b. los dedos & c. la mano & d. el brazo \\
\hline 3. & a. adelgazar & b. la receta & c. el jarabe & d. la pastilla \\
\hline 4. & a. el archivador & b. el cubículo & c. el gerente & d. la oficina \\
\hline 5. & a. administrar & b. dirigir & c. supervisar & d. recetar \\
\hline 6. & a. la palmera & b. el hielo & c. el cocotero & d. el arbusto \\
\hline 7. & a. el oso & b. el mono & c. la foca & d. el cangrejo \\
\hline 8. & a. el mar & b. las olas & c. el pantano & d. la sierra \\
\hline 9. & a. desperdiciar & b. reciclar & c. reutilizar & d. conservar \\
\hline 10. & a. la impresora & b. los altavoces & c. el ratón & d. la fibra óptica \\
\hline
\end{tabular}

B. Clasificaciones. Complete la siguiente tabla (8 puntos)

\begin{tabular}{||llll||}
\hline Ahorrar dinero & El resfriado & El desastre ambiental & Estar mareado \\
La fiebre & Los desechos urbanos & Manejar el tiempo & Ser carismático \\
Planear la jubilación & Hablar otro idioma & La tos & Pagar las cuentas \\
Ser íntegro & La excavación minera & Tener don de gentes & La población densa \\
\hline
\end{tabular}

\begin{tabular}{|l|l|l|l|}
\hline $\begin{array}{c}\text { Los problemas } \\
\text { ambientales }\end{array}$ & $\begin{array}{c}\text { Los retos de la vida } \\
\text { moderna }\end{array}$ & $\begin{array}{c}\text { Las enfermedades y los } \\
\text { síntomas }\end{array}$ & Cualidades Profesionales \\
\hline & & & \\
\hline & & & \\
\hline & & & \\
\hline
\end{tabular}


C. El Mundo Natural. Conteste las siguientes preguntas. No puede repetir información (4 puntos, 0.5 cada uno)

1. ¿Qué productos reciclas? Mencione dos

$\mathrm{y}$

2. ¿Cuáles son dos amenazas o problemas ambientales en Morgantown?

$\mathrm{y}$

3. Mencione dos especies en peligro de extinción:

$\mathrm{y}$

4. ¿Cuáles son dos tipos de energía renovable?

$\mathrm{y}$

D. La tecnología y la comunicación: Lea las definiciones y complete con la palabra del recuadro. (6 puntos)

\begin{tabular}{|lll|}
\hline El carro híbrido & Los alimentos transgénicos & buscar información \\
La clonación & La página Web & El lápiz de memoria \\
\hline
\end{tabular}

1. Uso el internet para

2. funciona con gasolina y electricidad

3. permite almacenar documentos electrónicos para la clase

4. produce organismos genéticamente idénticos en un laboratorio

5. Fuente de información accesible por internet

6. Comida modificada a nivel molecular

E. Una el verbo en columna A con la palabra lógica en columna B. (5 puntos: 0,5 c/u) 
Las relaciones sentimentales

A

1. Llevarse bien

2. La pareja

4. La luna

5. Enamorarse

\section{Las profesiones y los oficios}

A

1. La veterinaria

2. El farmacéutico

3. El abogado

4. El albañil

5. El periodista
a. cariño
b. de miel
c. con alguien
d. de hecho
e. a primera vista

B
a. da las noticias
b. construye edificios
c. cura a los animales
d. prepara y vende medicamentos
e. defiende a los acusados

\section{Grammar Section}

A. Subjuntivo y conjunciones de subjuntivo. Elija la conjunción más lógica para la frase. (4 puntos).

1. Debemos trabajar en el problema de la contaminación cuando/hasta que se solucione.

2. Debemos promover el uso de energías renovables para que/sin que conservemos nuestros recursos no renovables.

3. El agujero en la capa de ozono seguirá aumentando para que/a menos que las personas dejen de usar pesticidas y químicos tóxicos.

4. Debemos evitar la caza de animales silvestres a menos que/para que no sean especies en peligro de extinción.

B. El subjuntivo. Llene los espacios con las formas del subjuntivo o el indicativo. (5 puntos)

1. La empresa busca a una secretaria que (hablar) inglés y chino.

2. Es necesario que (preservar) las especies vegetales en peligro.

3. Creo que Juan y Antonio (reciclar) los plásticos en casa.

4. El presidente de la compañía quiere que sus empleados (trabajar) 8 horas al día.

5. Esta tarde practicaremos yoga en el jardín tan pronto como tú (hacer) tu tarea.

B. Reflexivos y recíprocos. Complete el párrafo con la opción correcta del verbo. (5 puntos)

Durante los fines de semana, mis amigos y yo generalmente nos reunimos para salir juntos de fiesta. Primero 1 (yo: ducharse) en casa. Ellos también 2 (prepararse) y después 3 (nosotros: verse) en el club. Cuando no podemos reunirnos,

4 (llamarse) por teléfono celular y ${ }^{5}$ (contarse) nuestros problemas, pero siempre estamos pendientes el uno del otro. 
C. El futuro. Complete con la forma del futuro de los verbos entre paréntesis. (5 puntos)

El año próximo yo (terminar) de estudiar en WVU. Después de que me gradúe yo (trabajar) para una compañía importante. (poder) comprar un carro nuevo todos los años y (tener) una casa muy bonita. i (ser) muy exitoso/a!

D. El condicional. ¿Qué haría Ud. en las siguientes situaciones? Complete con el condicional usando sus propias ideas (3 puntos; 1,5 gramática, 1,5 contenido).

1. Con más tiempo,

2. Con mucho dinero,

3. Sin una computadora,

E. Cláusulas con 'si': Seleccione la opción correcta de los siguientes verbos. (5 puntos)

1. Si fuera millonario, una casa grande en Los Cabos.
a. compro
b. compraré
c. compraría

2. Si mi teléfono celular se dañara, ¡no sé qué
a. hago
b. haré
c. haría

3. Si estudio mucho para mis clases, buenas notas.
a. obtendré
b. obtengo
c. obtendría

4. Si mi amigo me llama por teléfono,
a. contesto
b. contestaba
c. contestaría

5. Si tuviera tiempo libre este fin de semana, a hacer deporte.
a. voy
b. ire
c. iría

G. El subjuntivo. Imagine que su mejor amigo/a tiene una cita el próximo viernes. Escriba TRES recomendaciones sobre qué debe hacer para tener una cita exitosa: dónde debe ir, qué puede vestir, qué sugiere comer, etc. Utilice el subjuntivo. Modelo: Te recomiendo que no utilices tu teléfono celular todo el tiempo durante la cita. (6 puntos; 3 contenido, 3 gramática) 


\section{Reading Section}

\section{¿Cuál es la peor combinación al volante?}

Los mensajes de texto SMS enviados por celular son una forma económica de comunicación. Según un estudio realizado en Estados Unidos por la agencia de seguridad 'NHTSA', resulta que casi el total de propietarios de celulares utilizan los SMS como forma de comunicación, y que un alto porcentaje de ellos llevan

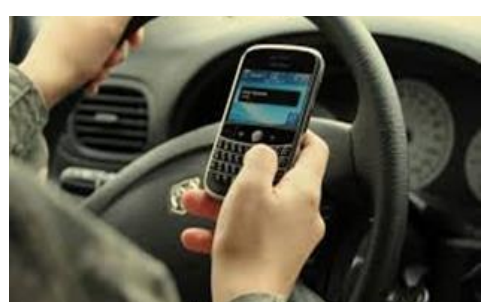
este hábito al momento de manejar. La agencia reportó que más de 6000 accidentes al año se deben a colisiones causadas por conductores que estaban distraídos enviando mensajes de texto. Como muchas otras distracciones mandar mensajes por el celular requiere cierta atención mental, lo que ha hecho que en ciertos países se prohíba realizar dicha actividad mientras se maneja.

Un nuevo estudio de la aseguradora State Farm reveló que los adolescentes consideran que enviar mensajes de texto cuando conducen un vehículo tiene menos consecuencias mortales que manejar ebrio (borracho). En la encuesta (survey), el 63\% de los adolescentes opinó que podrían tener un accidente si envían mensajes de texto mientras conducen.

Según una nueva ley firmada por el gobernador, el estado de Nueva York suspenderá la licencia de conducir a los jóvenes que envíen mensajes de texto cuando manejan. "Psychology Today" informa de que los adolescentes han visto a sus padres mandar mensajes de texto mientras conducían. Por lo tanto, cuando establezcamos límites en el envío de mensajes de texto, debemos tratar de aplicar esos mismos límites a toda la familia.

Tenemos mucho por hacer cuando se trata de ayudar a los adolescentes a comprender que enviar mensajes de texto mientras manejan puede ser tan peligroso como tomar alcohol mientras manejan. Una solución al problema es poner esos teléfonos en la guantera, en la cajuela o en el auto donde no se puedan alcanzar (reach). Si es necesario que conteste al teléfono, estaciónese a un lado de la carretera y apague el auto para responder. Por último, mantenga sus manos siempre al volante y considere utilizar dispositivos inalámbricos para la comunicación.

\section{A. Escoja la oración que representa la idea principal del texto ( 2 puntos).}

1. Conducir y enviar mensajes de texto tiene consecuencias peligrosas. 
2. Conducir y enviar mensajes de texto economiza el tiempo.

3. Conducir y enviar mensajes de texto es una buena combinación.

B. Señale si las siguientes oraciones son ciertas o falsas. (6 puntos; $1 \mathrm{pt} \mathrm{c} / \mathrm{u})$.

1. Todos los adolescentes consideran que enviar mensajes de texto cuando conducen un $\begin{array}{lll}\text { vehículo puede tener consecuencias mortales. } & \mathrm{C} & \mathrm{F}\end{array}$

2. En Nueva York se permite conducir y enviar mensajes sin sanciones. $\quad$ C F

3. Según el texto, debemos aplicar límites sólo a los adolescentes que envían SMS. $\quad$ C F

4. En algunos países, es ilegal conducir y enviar mensajes de texto al mismo tiempo. $\quad \mathrm{C} F$

5. Los adolescentes creen que manejar después de beber alcohol tiene más

$\begin{array}{lll}\text { consecuencias que manejar enviando mensajes de texto. } & \mathrm{C} & \mathrm{F}\end{array}$

$\begin{array}{lll}\text { 6. Enviar mensajes de texto requiere atención mental. } & \mathrm{C} & \mathrm{F}\end{array}$

\section{Escoja la respuesta correcta a las siguientes preguntas ( 2 puntos; 1 punto c/u).}

1. Según la revista Psychology Today, ¿a qué personas imitan los adolescentes cuando manejan y envían mensajes de texto?
a. A sus amigos
b. A sus padres
c. Al gobernador

2. Manejar y enviar SMS causa más de accidentes al año.
a. 5000
b. 6000
c. 7000

D. Según el texto, ¿qué recomendaciones podemos dar para evitar consecuencias peligrosas de manejar y enviar SMS? Escriba TRES recomendaciones mencionadas en el texto utilizando el subjuntivo. ( 3 puntos: 1,5 gramática, 1,5 contenido) 
E. ¡Ahora en la clase! Imagine que Ud. es un profesor de WVU y observa que sus estudiantes envían mensajes de texto durante la clase. ¿Qué diría o haría para evitar esta situación en la clase? ( 3 puntos: 1,5 gramática, 1,5 contenido). Utilice el condicional.

\section{Listening Section}

\section{Script of the Listening Section}

\section{[Los efectos beneficiosos de las hierbas medicinales] No leer título}

Las plantas con propiedades curativas se llaman hierbas medicinales. Hay miles de hierbas medicinales que contienen ingredientes activos. Cualquier parte de una planta medicinal, como hojas, tallos, flores y la raíz, puede ser utilizada con fines terapéuticos. Las plantas medicinales se utilizan como medicina alternativa y se usan desde antes de la llegada de los medicamentos modernos.

En los últimos tiempos, las hierbas medicinales se han hecho populares para el tratamiento de las enfermedades y para mejorar la salud en general. Muchas personas optan por la medicina herbal en lugar de medicamentos químicos, pues las hierbas tienen muy pocos o ningún efecto secundario a largo plazo.

Las plantas medicinales se pueden usar sin peligro para tratar problemas agudos comunes, como tos, dolor de cabeza o irritaciones; para tratar problemas crónicos, como depresiones leves y artritis; prevenir enfermedades y reforzar la salud.

Las hierbas pueden estimular la salud mental y física de forma muy eficaz. Estos remedios refuerzan la resistencia y la capacidad de soportar el estrés, ya sea para un estudiante que prepara exámenes o para un atleta que prepara una competición. Por ejemplo, antes de un examen o una entrevista de trabajo puede tomar hierbas como el romero para reforzar su vitalidad y concentración.

Es importante señalar que el efecto de estas hierbas medicinales varía de una persona a otra. El uso prolongado de las hierbas medicinales puede ser perjudicial para la salud. Siempre es recomendable consultar a un médico cualificado antes de tomar altas dosis de hierbas medicinales.

http://lasaludi.info/las-hierbas-en-la-medicina-alternativa.html

http://www.planta-medicinal.com/plantas-y-salud.html

\section{A. Indique cuál es la idea principal del texto escuchado ( 2 puntos).}


1. Los peligros de las hierbas medicinales para la salud

2. Los efectos secundarios de las hierbas medicinales

3. Los efectos beneficiosos de las hierbas medicinales

B. Escoja la respuesta correcta (2 puntos).

1. Las hierbas medicinales son plantas
a. con propiedades curativas
b. modificadas genéticamente
c. naturales

2. ¿Qué partes de una hierba medicinal pueden utilizarse con fines terapéuticos?
a. todas las partes
b. algunas partes
c. ninguna parte

C. Indique si las siguientes oraciones son ciertas o falsas ( 4 puntos)

1. Las hierbas medicinales ya se usaban antes de los medicamentos modernos. $\quad$ C F

2. Estas hierbas no son muy populares actualmente. $\quad$ C F

3. Las hierbas medicinales no tienen efectos secundarios a largo plazo. $\quad$ C F

4. No es necesario consultar con un médico para tomar muchas hierbas medicinales. $\quad \mathrm{C} F$

D. Conteste las siguientes preguntas según la información escuchada (5 puntos).

1. ¿Qué problemas podemos tratar con hierbas medicinales? Mencione tres.

2. ¿En qué situaciones podemos mejorar nuestra concentración con las hierbas medicinales? Mencione dos.

\section{E. Relacione las dos columnas con conceptos del texto (4 puntos).}

1. Las hierbas a. Tienen muchos efectos secundarios

2. El romero b. Estimula la salud mental y corporal

3. La planta medicinal c. No son peligrosas

4. Los medicamentos químicos d. Mejora la concentración y vitalidad

F. Recomendaciones. Las hierbas medicinales pueden ayudar a llevar un estilo de vida saludable, pero existen otras formas de aliviar el estrés. En su opinión, ¿qué necesita un estudiante para 
afrontar los retos de la vida moderna? Dé 4 recomendaciones a un estudiante de WVU estresado. Ejemplo: Le aconsejo que haga ejercicio para relajarse. (4 puntos; 2 contenido, 1 vocabulario, 1 gramática).

\section{Culture Section}

F. Cultura: el estilo de vida del Cono Sur. Escoja UNO de los siguientes temas y conteste las preguntas.

a) Las hierbas medicinales son populares en todo el mundo hispano. Un tipo de hierba muy consumida en el Cono Sur es el mate. Esta bebida es también una característica de los gauchos argentinos. ¿Qué otras características van asociadas al gaucho? ¿Dónde vive? ¿Qué profesión tiene? ¿Por qué es una figura importante?

b) La alimentación saludable forma parte del estilo de vida español y latinoamericano. Los productos de la agricultura orgánica son cada vez más populares. ¿Qué ventajas tienen este tipo de productos para el medio ambiente y la salud? ¿Consume usted productos orgánicos? ¿Por qué?

c) Bailar es una parte esencial del estilo de vida hispano. El tango es un tipo de baile popular en todo el mundo. ¿Dónde nació el tango? ¿Qué representa para este país? ¿Qué instrumentos se utilizan en el tango?

(5 puntos; 3 contenido, 2 vocabulario, 1 gramática)

Note. This exam shows the structure of the Spanish exam in Spring 20015 that involves: vocabulary ,grammar, reading, culture and listening. 


\section{Appendix $\mathbf{J}$}

Script of the video NAME: $\quad$ EXP/Control and Topic:

This student produced:

\# sentences.

Errors found in sentences \#:

Global Accuracy

\begin{tabular}{|l|l|l|l|l|}
\hline Student & \# Total of clauses & $\begin{array}{l}\text { \# Clauses with } \\
\text { Errors }\end{array}$ & $\begin{array}{l}\text { \# Error-Free } \\
\text { Clauses }\end{array}$ & $\begin{array}{l}\text { \# Error-Free Clauses / } \\
\text { Total of Clauses }\end{array}$ \\
\hline & & & & \\
\hline
\end{tabular}

Specific Accuracy

\begin{tabular}{|l|l|l|l|l|l|l|}
\hline Student & $\begin{array}{l}\text { \# Total } \\
\text { of Verbs }\end{array}$ & $\begin{array}{l}\text { \# Verb } \\
\text { Errors }\end{array}$ & $\begin{array}{l}\text { \# Correct verb } \\
\text { /Total of verbs }\end{array}$ & $\begin{array}{l}\text { \#Total } \\
\text { articles }\end{array}$ & $\begin{array}{l}\text { \# Articles } \\
\text { Errors }\end{array}$ & $\begin{array}{l}\text { \# Correct articles } \\
\text { /Total of articles }\end{array}$ \\
\hline & & & & & & \\
\hline
\end{tabular}

Note: This script was filled up for every L2 student of experimental and control group. Errors different to articles and verbs, and sentences read from notes were not counted in this study. 


\section{Appendix J 1}

Script of the video NAME: 1 EXP/Control and Topic: El café de Nicaragua

1) Es mucho calor afuera.

2) Cuesta mucho dinero y tiempo.

3) Es muy bien.

4) xxx personas están ayudando a los agricultores.

This student produced: 4 sentences.

Errors found in sentences: 1,3 .

Global Accuracy

\begin{tabular}{|l|l|l|l|l|}
\hline Student & \# Total of clauses & $\begin{array}{l}\text { \# Clauses with } \\
\text { Errors }\end{array}$ & $\begin{array}{l}\text { \# Error-Free } \\
\text { Clauses }\end{array}$ & $\begin{array}{l}\text { \# Error-Free Clauses / Total } \\
\text { of Clauses }\end{array}$ \\
\hline 1 & 4 & 2 & 2 & $2 / 4$ \\
\hline
\end{tabular}

Specific Accuracy

\begin{tabular}{|l|l|l|l|l|l|l|}
\hline Student & $\begin{array}{l}\text { \# Total of } \\
\text { Verbs }\end{array}$ & $\begin{array}{l}\text { \# Verb } \\
\text { Errors }\end{array}$ & $\begin{array}{l}\text { \# Correct verb } \\
\text { /Total of verbs }\end{array}$ & $\begin{array}{l}\text { \#Total } \\
\text { articles }\end{array}$ & $\begin{array}{l}\text { \# Articles } \\
\text { Errors }\end{array}$ & $\begin{array}{l}\text { \# Correct articles } \\
\text { /Total of articles }\end{array}$ \\
\hline 1 & 5 & 2 & $3 / 5$ & 1 & 0 & $1 / 1$ \\
\hline
\end{tabular}

Note: This script was filled up for every L2 student of experimental and control group. Errors different to articles and verbs, and sentences read from notes were not counted in this study. 


\section{Appendix $\mathbf{J} 2$}

Script of the video NAME: 2 EXP/Control and Topic: La Comida de Argentina

1) El dulce de leche es la leche y $\underline{00}$ azúcar.

2) Es muy delicioso.

3) Se bebida con los amigos.

This student produced: 3 sentences.

Errors found in sentences: 1, 3 .

Note: errors different to articles, verbs, and sentences read from notes were not counted.

Global Accuracy

\begin{tabular}{|l|l|l|l|l|}
\hline Student & \# Total of clauses & $\begin{array}{l}\text { \# Clauses with } \\
\text { Errors }\end{array}$ & $\begin{array}{l}\text { \# Error-Free } \\
\text { Clauses }\end{array}$ & $\begin{array}{l}\text { \# Error-Free Clauses / Total } \\
\text { of Clauses }\end{array}$ \\
\hline 2 & 3 & 2 & 1 & $1 / 3$ \\
\hline
\end{tabular}

Specific Accuracy

\begin{tabular}{|l|l|l|l|l|l|l|}
\hline Student & $\begin{array}{l}\text { \# Total of } \\
\text { Verbs }\end{array}$ & $\begin{array}{l}\text { \# Verb } \\
\text { Errors }\end{array}$ & $\begin{array}{l}\text { \# Correct verb } \\
\text { /Total of verbs }\end{array}$ & $\begin{array}{l}\text { \#Total } \\
\text { articles }\end{array}$ & $\begin{array}{l}\text { \# Articles } \\
\text { Errors }\end{array}$ & $\begin{array}{l}\text { \# Correct articles } \\
\text { /Total of articles }\end{array}$ \\
\hline 2 & 3 & 1 & $2 / 3$ & 3 & 1 & $1 / 3$ \\
\hline
\end{tabular}

Note: This script was filled up for every L2 student of experimental and control group. Errors different to articles and verbs, and sentences read from notes were not counted in this study. 


\section{Appendix J 3}

Script of the video NAME: 3 EXP/Control and Topic: Música Pop en Latinoamérica

1) Riki Martin empezó su carrera como un conjunto musical.

2) Ha realizado varios álbumes.

3) En 1999 grabó "vive la vida loca".

4) Empezó la explosión de la música pop en el mundo.

5) Jennifer López empezó su carrera como un bailarina.

This student produced: 5 sentences.

Errors found in sentence: 5 .

Global Accuracy

\begin{tabular}{|l|l|l|l|l|}
\hline Student & \# Total of clauses & $\begin{array}{l}\text { \# Clauses with } \\
\text { Errors }\end{array}$ & $\begin{array}{l}\text { \# Error-Free } \\
\text { Clauses }\end{array}$ & $\begin{array}{l}\text { \# Error-Free Clauses / Total } \\
\text { of Clauses }\end{array}$ \\
\hline 3 & 5 & 1 & 4 & $4 / 5$ \\
\hline
\end{tabular}

Specific Accuracy

\begin{tabular}{|l|l|l|l|l|l|l|}
\hline Student & $\begin{array}{l}\text { \# Total of } \\
\text { Verbs }\end{array}$ & $\begin{array}{l}\text { \# Verb } \\
\text { Errors }\end{array}$ & $\begin{array}{l}\text { \# Correct verb } \\
\text { /Total of verbs }\end{array}$ & $\begin{array}{l}\text { \#Total } \\
\text { articles }\end{array}$ & $\begin{array}{l}\text { \# Articles } \\
\text { Errors }\end{array}$ & $\begin{array}{l}\text { \# Correct articles } \\
\text { /Total of articles }\end{array}$ \\
\hline 3 & 7 & 0 & $7 / 7$ & 6 & 1 & $5 / 6$ \\
\hline
\end{tabular}

Note: This script was filled up for every L2 student of experimental and control group. Errors different to articles and verbs, and sentences read from notes were not counted in this study. 


\section{Appendix $\mathbf{J} 4$}

Script of the video NAME: $4 \quad$ EXP/Control and Topic: Cultura de Argentina

1) Se celebra 00 de 10 noviembre.

2) José Hernández era un escritor un gaucho y un poeta.

3) Los vendedores venden comida como mate y el asado.

4) Es muy grande.

5) Se considera una vacación popular no hay escuela o trabajo.

This student produced: 5 sentences.

Errors found in sentences: 1

Global Accuracy

\begin{tabular}{|l|l|l|l|l|}
\hline Student & \# Total of clauses & $\begin{array}{l}\text { \# Clauses with } \\
\text { Errors }\end{array}$ & $\begin{array}{l}\text { \# Error-Free } \\
\text { Clauses }\end{array}$ & $\begin{array}{l}\text { \# Error-Free Clauses / } \\
\text { Total of Clauses }\end{array}$ \\
\hline 4 & 5 & 1 & 4 & $4 / 5$ \\
\hline
\end{tabular}

Specific Accuracy

\begin{tabular}{|l|l|l|l|l|l|l|}
\hline Student & $\begin{array}{l}\text { \# Total } \\
\text { of Verbs }\end{array}$ & $\begin{array}{l}\text { \# Verb } \\
\text { Errors }\end{array}$ & $\begin{array}{l}\text { \# Correct verb } \\
\text { /Total of verbs }\end{array}$ & $\begin{array}{l}\text { \#Total } \\
\text { articles }\end{array}$ & $\begin{array}{l}\text { \# Articles } \\
\text { Errors }\end{array}$ & $\begin{array}{l}\text { \# Correct articles } \\
\text { /Total of articles }\end{array}$ \\
\hline 4 & 6 & 0 & $6 / 6$ & 6 & 1 & $5 / 6$ \\
\hline
\end{tabular}

Note: This script was filled up for every L2 student of experimental and control group. Errors different to articles and verbs, and sentences read from notes were not counted in this study. 


\section{Appendix J 5}

\section{Script of the video NAME: 5 EXP/Control and Topic: Los Conquistadores}

1) Hace muchos años la gente de América y Suramérica no hablaban español.

2) Había muchas lenguas de las indígenas pero todo cambia en el siglo XV.

3) Cuando los conquistadores llegaron a Suramérica todas las cosas cambian.

4)Los xxxs se dirigían por xxx de España.

5) Cristóbal Colón vino primero a Suramérica y al Caribe.

This student produced: 5 sentences

Errors found in sentences: 2

Global Accuracy

\begin{tabular}{|l|l|l|l|l|}
\hline Student & \# Total of clauses & $\begin{array}{l}\text { \# Clauses with } \\
\text { Errors }\end{array}$ & $\begin{array}{l}\text { \# Error-Free } \\
\text { Clauses }\end{array}$ & $\begin{array}{l}\text { \# Error-Free Clauses / } \\
\text { Total of Clauses }\end{array}$ \\
\hline 5 & 5 & 1 & 4 & $4 / 5$ \\
\hline
\end{tabular}

Specific Accuracy

\begin{tabular}{|l|l|l|l|l|l|l|}
\hline Student & $\begin{array}{l}\text { \# Total } \\
\text { of Verbs }\end{array}$ & $\begin{array}{l}\text { \# Verb } \\
\text { Errors }\end{array}$ & $\begin{array}{l}\text { \# Correct verb } \\
\text { /Total of verbs }\end{array}$ & $\begin{array}{l}\text { \#Total } \\
\text { articles }\end{array}$ & $\begin{array}{l}\text { \# Articles } \\
\text { Errors }\end{array}$ & $\begin{array}{l}\text { \# Correct articles } \\
\text { /Total of articles }\end{array}$ \\
\hline 5 & 8 & 0 & $8 / 8$ & 8 & 1 & $7 / 8$ \\
\hline
\end{tabular}

Note: This script was filled up for every L2 student of experimental and control group. Errors different to articles and verbs, and sentences read from notes were not counted in this study. 


\section{Appendix J 6}

Script of the video NAME: $6 \quad$ EXP/Control and Topic: La ropa de América Latina

1)En Panamá llevan la moda.

2)La moda es una parte de la cultura.

3)Los mujeres pueden crear obras de arte.

4)La moda tiene varios usos como el desfile de moda.

5)En Panamá la moda ha sido un símbolo de xxxx y cultura.

This student produced: 5 sentences

Errors found in sentences: 3

Global Accuracy

\begin{tabular}{|l|l|l|l|l|}
\hline Student & \# Total of clauses & $\begin{array}{l}\text { \# Clauses with } \\
\text { Errors }\end{array}$ & $\begin{array}{l}\text { \# Error-Free } \\
\text { Clauses }\end{array}$ & $\begin{array}{l}\text { \# Error-Free Clauses / } \\
\text { Total of Clauses }\end{array}$ \\
\hline 6 & 5 & 1 & 4 & $4 / 5$ \\
\hline
\end{tabular}

Specific Accuracy

\begin{tabular}{|l|l|l|l|l|l|l|}
\hline Student & $\begin{array}{l}\text { \# Total } \\
\text { of Verbs }\end{array}$ & $\begin{array}{l}\text { \# Verb } \\
\text { Errors }\end{array}$ & $\begin{array}{l}\text { \# Correct verb } \\
\text { /Total of verbs }\end{array}$ & $\begin{array}{l}\text { \#Total } \\
\text { articles }\end{array}$ & $\begin{array}{l}\text { \# Articles } \\
\text { Errors }\end{array}$ & $\begin{array}{l}\text { \# Correct articles } \\
\text { /Total of articles }\end{array}$ \\
\hline 6 & 7 & 0 & $7 / 7$ & 9 & 1 & $8 / 9$ \\
\hline
\end{tabular}

Note: This script was filled up for every L2 student of experimental and control group. Errors different to articles and verbs, and sentences read from notes were not counted in this study. 


\section{Appendix J 7}

Script of the video NAME: 7 EXP/Control and Topic: La ropa de América Latina

1) La ropa de América Latina es muy similar.

2) Muchos latinos vivan del mismo origen.

3) La ropa es muy vistosa con los colores de la bandera.

4)) Llevan vestidos largos hasta el piso y blusas que dejan ver el hombro

5) Las faldas tienen mucho color y estampados todas.

This student produced: 5 sentences.

Errors found in sentences: 2

Global Accuracy

\begin{tabular}{|l|l|l|l|l|}
\hline Student & \# Total of clauses & $\begin{array}{l}\text { \# Clauses with } \\
\text { Errors }\end{array}$ & $\begin{array}{l}\text { \# Error-Free } \\
\text { Clauses }\end{array}$ & $\begin{array}{l}\text { \# Error-Free Clauses / } \\
\text { Total of Clauses }\end{array}$ \\
\hline 7 & 5 & 1 & 4 & $4 / 5$ \\
\hline
\end{tabular}

Specific Accuracy

\begin{tabular}{|l|l|l|l|l|l|l|}
\hline Student & $\begin{array}{l}\text { \# Total } \\
\text { of Verbs }\end{array}$ & $\begin{array}{l}\text { \# Verb } \\
\text { Errors }\end{array}$ & $\begin{array}{l}\text { \# Correct verb } \\
\text { /Total of verbs }\end{array}$ & $\begin{array}{l}\text { \#Total } \\
\text { articles }\end{array}$ & $\begin{array}{l}\text { \# Articles } \\
\text { Errors }\end{array}$ & $\begin{array}{l}\text { \# Correct articles } \\
\text { /Total of articles }\end{array}$ \\
\hline 7 & 7 & 1 & $6 / 7$ & 8 & 0 & $8 / 8$ \\
\hline
\end{tabular}

Note: This script was filled up for every L2 student of experimental and control group. Errors different to articles and verbs, and sentences read from notes were not counted in this study. 


\section{Appendix $\mathbf{J} 8$}

\section{Script of the video NAME: 8 EXP/Control and Topic: Los conquistadores}

1) Los conquistadores conquistan los aztecas.

2) Entran a la ciudad y en las casas de los aztecas.

3) Es una idea para asesinar a los aztecas.

4) Antes de la mañana los conquistadores atacan y asesinan.

5) Tenochtitlán es la capital de los aztecas

This student produced: 5 sentences.

Errors found in sentences: 0

Global Accuracy

\begin{tabular}{|l|l|l|l|l|}
\hline Student & \# Total of clauses & $\begin{array}{l}\text { \# Clauses with } \\
\text { Errors }\end{array}$ & $\begin{array}{l}\text { \# Error-Free } \\
\text { Clauses }\end{array}$ & $\begin{array}{l}\text { \# Error-Free Clauses / } \\
\text { Total of Clauses }\end{array}$ \\
\hline 8 & 5 & 0 & 5 & $5 / 5$ \\
\hline
\end{tabular}

Specific Accuracy

\begin{tabular}{|l|l|l|l|l|l|l|}
\hline Student & $\begin{array}{l}\text { \# Total } \\
\text { of Verbs }\end{array}$ & $\begin{array}{l}\text { \# Verb } \\
\text { Errors }\end{array}$ & $\begin{array}{l}\text { \# Correct verb } \\
\text { /Total of verbs }\end{array}$ & $\begin{array}{l}\text { \#Total } \\
\text { articles }\end{array}$ & $\begin{array}{l}\text { \# Articles } \\
\text { Errors }\end{array}$ & $\begin{array}{l}\text { \# Correct articles } \\
\text { /Total of articles }\end{array}$ \\
\hline 8 & 7 & 0 & $7 / 7$ & 11 & 0 & $11 / 11$ \\
\hline
\end{tabular}

Note: This script was filled up for every L2 student of experimental and control group. Errors different to articles and verbs, and sentences read from notes were not counted in this study. 


\section{Appendix J9}

Script of the video NAME: $9 \quad$ EXP/Control and Topic: Los conquistadores

1) Los conquistadores eran codiciosos.

2) Querían cosas valiosas como $\underline{00}$ oro y la plata.

3) Su lema $\underline{00}$ por oro dios y gloria.

4) xx mantuvo a los conquistadores motivados.

This student produced: 4 sentences.

Errors found in sentences: 2, 3 .

Global Accuracy

\begin{tabular}{|l|l|l|l|l|}
\hline Student & \# Total of clauses & $\begin{array}{l}\text { \# Clauses with } \\
\text { Errors }\end{array}$ & $\begin{array}{l}\text { \# Error-Free } \\
\text { Clauses }\end{array}$ & $\begin{array}{l}\text { \# Error-Free Clauses / } \\
\text { Total of Clauses }\end{array}$ \\
\hline 9 & 4 & 2 & 2 & $2 / 4$ \\
\hline
\end{tabular}

Specific Accuracy

\begin{tabular}{|l|l|l|l|l|l|l|}
\hline Student & $\begin{array}{l}\text { \# Total } \\
\text { of Verbs }\end{array}$ & $\begin{array}{l}\text { \# Verb } \\
\text { Errors }\end{array}$ & $\begin{array}{l}\text { \# Correct verb } \\
\text { /Total of verbs }\end{array}$ & $\begin{array}{l}\text { \#Total } \\
\text { articles }\end{array}$ & $\begin{array}{l}\text { \# Articles } \\
\text { Errors }\end{array}$ & $\begin{array}{l}\text { \# Correct articles } \\
\text { /Total of articles }\end{array}$ \\
\hline 9 & 5 & 1 & $4 / 5$ & 4 & 1 & $3 / 4$ \\
\hline
\end{tabular}

Note: This script was filled up for every L2 student of experimental and control group. Errors different to articles and verbs, and sentences read from notes were not counted in this study. 
Appendix J10

Script of the video NAME: $10 \quad$ EXP/Control and Topic: El fútbol

1)Se juego como deporte en China.

2) La primera pelota fue la cabeza de xxxx.

This student produced: 2 sentences.

Errors found in sentences: 1

Global Accuracy

\begin{tabular}{|l|l|l|l|l|}
\hline Student & $\begin{array}{l}\text { \# Total of } \\
\text { clauses }\end{array}$ & $\begin{array}{l}\text { \# Clauses with } \\
\text { Errors }\end{array}$ & $\begin{array}{l}\text { \# Error-Free } \\
\text { Clauses }\end{array}$ & $\begin{array}{l}\text { \# Error-Free Clauses } \\
\text { / Total of Clauses }\end{array}$ \\
\hline 10 & 2 & 1 & 1 & $1 / 2$ \\
\hline
\end{tabular}

Specific Accuracy

\begin{tabular}{|l|l|l|l|l|l|l|}
\hline Student & $\begin{array}{l}\text { \# Total } \\
\text { of Verbs }\end{array}$ & $\begin{array}{l}\text { \# Verb } \\
\text { Errors }\end{array}$ & $\begin{array}{l}\text { \# Correct } \\
\text { verb /Total of } \\
\text { verbs }\end{array}$ & $\begin{array}{l}\text { \#Total } \\
\text { articles }\end{array}$ & $\begin{array}{l}\text { \# } \\
\text { Articles } \\
\text { Errors }\end{array}$ & $\begin{array}{l}\text { \# Correct } \\
\text { articles /Total of } \\
\text { articles }\end{array}$ \\
\hline 10 & 2 & 1 & $1 / 2$ & 2 & 0 & $2 / 2$ \\
\hline
\end{tabular}

Note: This script was filled up for every L2 student of experimental and control group. Errors different to articles and verbs, and sentences read from notes were not counted in this study. 


\section{Appendix J11}

Script of the video NAME: 11 EXP/Control and Topic: Finca de café

Nicaragua.

1) Es muy difícil

2) Es muy peligroso

3) Las mujeres también siembran para ellas mismas.

This student produced: 3 sentences.

Errors found in sentence: 0

Global Accuracy

\begin{tabular}{|l|l|l|l|l|}
\hline Student & $\begin{array}{l}\text { \# Total of } \\
\text { clauses }\end{array}$ & $\begin{array}{l}\text { \# Clauses with } \\
\text { Errors }\end{array}$ & $\begin{array}{l}\text { \# Error-Free } \\
\text { Clauses }\end{array}$ & $\begin{array}{l}\text { \# Error-Free Clauses } \\
\text { / Total of Clauses }\end{array}$ \\
\hline 11 & 3 & 0 & 3 & $3 / 3$ \\
\hline
\end{tabular}

Specific Accuracy

\begin{tabular}{|l|l|l|l|l|l|l|}
\hline Student & $\begin{array}{l}\text { \# Total } \\
\text { of Verbs }\end{array}$ & $\begin{array}{l}\text { \# Verb } \\
\text { Errors }\end{array}$ & $\begin{array}{l}\text { \# Correct } \\
\text { verb /Total of } \\
\text { verbs }\end{array}$ & $\begin{array}{l}\text { \#Total } \\
\text { articles }\end{array}$ & $\begin{array}{l}\text { \# } \\
\text { Articles } \\
\text { Errors }\end{array}$ & $\begin{array}{l}\text { \# Correct } \\
\text { articles /Total of } \\
\text { articles }\end{array}$ \\
\hline 11 & 3 & 0 & $3 / 3$ & 1 & 0 & $1 / 1$ \\
\hline
\end{tabular}

Note: This script was filled up for every L2 student of experimental and control group. Errors different to articles and verbs, and sentences read from notes were not counted in this study. 


\section{Appendix J12}

Script of the video NAME: 12 EXP/Control and Topic: Cultura de Argentina

1)Los españoles y otros países de Europa se opusieron a la cultura.

2) La cultura es muy diferente.

3) La comunicación es muy diferente.

4) La gente es diferente en Argentina.

5) Cuando ellos hablan usan los manos como un chica.

This student produced: 5 sentences.

Errors found in sentence: 5

Global Accuracy

\begin{tabular}{|l|l|l|l|l|}
\hline Student & $\begin{array}{l}\text { \# Total of } \\
\text { clauses }\end{array}$ & $\begin{array}{l}\text { \# Clauses with } \\
\text { Errors }\end{array}$ & $\begin{array}{l}\text { \# Error-Free } \\
\text { Clauses }\end{array}$ & $\begin{array}{l}\text { \# Error-Free Clauses } \\
\text { / Total of Clauses }\end{array}$ \\
\hline 12 & 5 & 1 & 4 & $4 / 5$ \\
\hline
\end{tabular}

Specific Accuracy

\begin{tabular}{|l|l|l|l|l|l|l|}
\hline Student & $\begin{array}{l}\text { \# Total } \\
\text { of Verbs }\end{array}$ & $\begin{array}{l}\text { \# Verb } \\
\text { Errors }\end{array}$ & $\begin{array}{l}\text { \# Correct } \\
\text { verb /Total of } \\
\text { verbs }\end{array}$ & $\begin{array}{l}\text { \#Total } \\
\text { articles }\end{array}$ & $\begin{array}{l}\text { \# } \\
\text { Articles } \\
\text { Errors }\end{array}$ & $\begin{array}{l}\text { \# Correct } \\
\text { articles /Total of } \\
\text { articles }\end{array}$ \\
\hline 12 & 6 & 0 & $6 / 6$ & 7 & 2 & $5 / 7$ \\
\hline
\end{tabular}

Note: This script was filled up for every L2 student of experimental and control group. Errors different to articles and verbs, and sentences read from notes were not counted in this study. 


\section{Appendix J13}

Script of the video NAME: 13 EXP/Control and Topic: $\quad$ Dalí

\section{1) También Dalí fue influido. \\ 2)Encontró inspiración artística. \\ 3)Está un poco loco. \\ 4)Hizo esculturas como el teléfono xxxx.}

This student produced: 4 sentences.

Errors found in sentence: 3

Global Accuracy

\begin{tabular}{|l|l|l|l|l|}
\hline Student & $\begin{array}{l}\text { \# Total of } \\
\text { clauses }\end{array}$ & $\begin{array}{l}\text { \# Clauses with } \\
\text { Errors }\end{array}$ & $\begin{array}{l}\text { \# Error-Free } \\
\text { Clauses }\end{array}$ & $\begin{array}{l}\text { \# Error-Free Clauses } \\
\text { / Total of Clauses }\end{array}$ \\
\hline 13 & 4 & 1 & 3 & $3 / 4$ \\
\hline
\end{tabular}

Specific Accuracy

\begin{tabular}{|l|l|l|l|l|l|l|}
\hline Student & $\begin{array}{l}\text { \# Total } \\
\text { of Verbs }\end{array}$ & $\begin{array}{l}\text { \# Verb } \\
\text { Errors }\end{array}$ & $\begin{array}{l}\text { \# Correct } \\
\text { verb /Total of } \\
\text { verbs }\end{array}$ & $\begin{array}{l}\text { \#Total } \\
\text { articles }\end{array}$ & $\begin{array}{l}\text { \# } \\
\text { Articles } \\
\text { Errors }\end{array}$ & $\begin{array}{l}\text { \# Correct } \\
\text { articles /Total of } \\
\text { articles }\end{array}$ \\
\hline 13 & 5 & 1 & $4 / 5$ & 2 & 0 & $2 / 2$ \\
\hline
\end{tabular}

Note: This script was filled up for every L2 student of experimental and control group. Errors different to articles and verbs, and sentences read from notes were not counted in this study. 


\section{Appendix J14}

Script of the video NAME: 14 EXP/Control and Topic: Ropa tradicional mejicana

This student did not produce sentences, just read.

This student produced: 0 sentences.

Errors found in sentence: 0

Global Accuracy

\begin{tabular}{|l|l|l|l|l|}
\hline Student & $\begin{array}{l}\text { \# Total of } \\
\text { clauses }\end{array}$ & $\begin{array}{l}\text { \# Clauses with } \\
\text { Errors }\end{array}$ & $\begin{array}{l}\text { \# Error-Free } \\
\text { Clauses }\end{array}$ & $\begin{array}{l}\text { \# Error-Free Clauses } \\
\text { / Total of Clauses }\end{array}$ \\
\hline 14 & 0 & 0 & 0 & 0 \\
\hline
\end{tabular}

Specific Accuracy

\begin{tabular}{|l|l|l|l|l|l|l|}
\hline Student & $\begin{array}{l}\text { \# Total } \\
\text { of Verbs }\end{array}$ & $\begin{array}{l}\text { \# Verb } \\
\text { Errors }\end{array}$ & $\begin{array}{l}\text { \# Correct } \\
\text { verb /Total of } \\
\text { verbs }\end{array}$ & $\begin{array}{l}\text { \#Total } \\
\text { articles }\end{array}$ & $\begin{array}{l}\text { \# } \\
\text { Articles } \\
\text { Errors }\end{array}$ & $\begin{array}{l}\text { \# Correct } \\
\text { articles /Total of } \\
\text { articles }\end{array}$ \\
\hline 14 & 0 & 0 & 0 & 0 & 0 & 0 \\
\hline
\end{tabular}

Note: This script was filled up for every L2 student of experimental and control group. Errors different to articles and verbs, and sentences read from notes were not counted in this study. 


\section{Appendix J15}

Script of the video NAME: 15 EXP/Control and Topic: La comida de España.

1)En España es tres comidas típicas en $\underline{00}$ día.

2)Se sirve y se toma el café, zumo, leche o cereales.

3)Los días especiales se come chocolate con churros.

4) $\underline{00}$ muy delicioso.

5)El segundo es la comida.

This student produced: 5 sentences.

Errors found in sentence: 1,4

Global Accuracy

\begin{tabular}{|l|l|l|l|l|}
\hline Student & $\begin{array}{l}\text { \# Total of } \\
\text { clauses }\end{array}$ & $\begin{array}{l}\text { \# Clauses with } \\
\text { Errors }\end{array}$ & $\begin{array}{l}\text { \# Error-Free } \\
\text { Clauses }\end{array}$ & $\begin{array}{l}\text { \# Error-Free Clauses } \\
\text { / Total of Clauses }\end{array}$ \\
\hline 15 & 5 & 2 & 3 & $3 / 5$ \\
\hline
\end{tabular}

Specific Accuracy

\begin{tabular}{|l|l|l|l|l|l|l|}
\hline Student & $\begin{array}{l}\text { \# Total } \\
\text { of Verbs }\end{array}$ & $\begin{array}{l}\text { \# Verb } \\
\text { Errors }\end{array}$ & $\begin{array}{l}\text { \# Correct } \\
\text { verb /Total of } \\
\text { verbs }\end{array}$ & $\begin{array}{l}\text { \#Total } \\
\text { articles }\end{array}$ & $\begin{array}{l}\text { \# } \\
\text { Articles } \\
\text { Errors }\end{array}$ & $\begin{array}{l}\text { \# Correct } \\
\text { articles /Total of } \\
\text { articles }\end{array}$ \\
\hline 15 & 6 & 2 & $4 / 6$ & 4 & 1 & $3 / 4$ \\
\hline
\end{tabular}

Note: This script was filled up for every L2 student of experimental and control group. Errors different to articles and verbs, and sentences read from notes were not counted in this study. 
Appendix J16

Script of the video NAME: $16 \quad$ EXP/Control and Topic: La música de Puerto

Rico

1) Nosotros presentaremos sobre Puerto Rico.

2) Primero es la música.

3) La gente de Puerto Rico mantiene cuatro tipos de música.

4) Representa la historia de sus habitantes.

5) Es similar a la música de los Estados Unidos.

This student produced: 5 sentences.

Errors found in sentence: 3

Global Accuracy

\begin{tabular}{|l|l|l|l|l|}
\hline Student & $\begin{array}{l}\text { \# Total of } \\
\text { clauses }\end{array}$ & $\begin{array}{l}\text { \# Clauses with } \\
\text { Errors }\end{array}$ & $\begin{array}{l}\text { \# Error-Free } \\
\text { Clauses }\end{array}$ & $\begin{array}{l}\text { \# Error-Free Clauses } \\
\text { / Total of Clauses }\end{array}$ \\
\hline 16 & 5 & 1 & 4 & $4 / 5$ \\
\hline
\end{tabular}

Specific Accuracy

\begin{tabular}{|l|l|l|l|l|l|l|}
\hline Student & $\begin{array}{l}\text { \# Total } \\
\text { of Verbs }\end{array}$ & $\begin{array}{l}\text { \# Verb } \\
\text { Errors }\end{array}$ & $\begin{array}{l}\text { \# Correct } \\
\text { verb /Total of } \\
\text { verbs }\end{array}$ & $\begin{array}{l}\text { \#Total } \\
\text { articles }\end{array}$ & $\begin{array}{l}\text { \# } \\
\text { Articles } \\
\text { Errors }\end{array}$ & $\begin{array}{l}\text { \# Correct } \\
\text { articles /Total of } \\
\text { articles }\end{array}$ \\
\hline 16 & 5 & 1 & $4 / 5$ & 6 & 0 & $5 / 5$ \\
\hline
\end{tabular}

Note: This script was filled up for every L2 student of experimental and control group. Errors different to articles and verbs, and sentences read from notes were not counted in this study. 


\section{Appendix J17}

Script of the video NAME: 17 EXP/Control and Topic: El Tango

1) El tango se originó en Buenos Aires, Argentina.

2) Esa imagen es el tango.

This student produced: 2 sentences.

Errors found in sentence: 0

Global Accuracy

\begin{tabular}{|l|l|l|l|l|}
\hline Student & $\begin{array}{l}\text { \# Total of } \\
\text { clauses }\end{array}$ & $\begin{array}{l}\text { \# Clauses with } \\
\text { Errors }\end{array}$ & $\begin{array}{l}\text { \# Error-Free } \\
\text { Clauses }\end{array}$ & $\begin{array}{l}\text { \# Error-Free Clauses } \\
\text { / Total of Clauses }\end{array}$ \\
\hline 17 & 2 & 0 & 2 & $2 / 2$ \\
\hline
\end{tabular}

Specific Accuracy

\begin{tabular}{|l|l|l|l|l|l|l|}
\hline Student & $\begin{array}{l}\text { \# Total } \\
\text { of Verbs }\end{array}$ & $\begin{array}{l}\text { \# Verb } \\
\text { Errors }\end{array}$ & $\begin{array}{l}\text { \# Correct } \\
\text { verb /Total of } \\
\text { verbs }\end{array}$ & $\begin{array}{l}\text { \#Total } \\
\text { articles }\end{array}$ & $\begin{array}{l}\# \\
\text { Articles } \\
\text { Errors }\end{array}$ & $\begin{array}{l}\text { \# Correct } \\
\text { articles /Total of } \\
\text { articles }\end{array}$ \\
\hline 17 & 2 & 0 & $2 / 2$ & 2 & 0 & $2 / 2$ \\
\hline
\end{tabular}

Note: This script was filled up for every L2 student of experimental and control group. Errors different to articles and verbs, and sentences read from notes were not counted in this study. 


\section{Appendix J18}

Script of the video NAME: 18 EXP/Control and Topic: Los Mariachis

1) Los mariachis son músicos de un tipo de música mejicana.

2) Los mariachis tocan instrumentos de cuerda y la trompeta.

3) Los instrumentos de cuerda incluyen la guitarra, la guitarrón y el violín.

4) La palabra mariachi tiene dos orígenes posibles.

5) El primero se origina de la palabra mariage.

This student produced: 5 sentences.

Errors found in sentence: 3

Global Accuracy

\begin{tabular}{|l|l|l|l|l|}
\hline Student & $\begin{array}{l}\text { \# Total of } \\
\text { clauses }\end{array}$ & $\begin{array}{l}\text { \# Clauses with } \\
\text { Errors }\end{array}$ & $\begin{array}{l}\text { \# Error-Free } \\
\text { Clauses }\end{array}$ & $\begin{array}{l}\text { \# Error-Free Clauses } \\
\text { / Total of Clauses }\end{array}$ \\
\hline 18 & 5 & 1 & 4 & $4 / 5$ \\
\hline
\end{tabular}

Specific Accuracy

\begin{tabular}{|l|l|l|l|l|l|l|}
\hline Student & $\begin{array}{l}\text { \# Total } \\
\text { of Verbs }\end{array}$ & $\begin{array}{l}\text { \# Verb } \\
\text { Errors }\end{array}$ & $\begin{array}{l}\text { \# Correct } \\
\text { verb /Total of } \\
\text { verbs }\end{array}$ & $\begin{array}{l}\text { \#Total } \\
\text { articles }\end{array}$ & $\begin{array}{l}\text { \# } \\
\text { Articles } \\
\text { Errors }\end{array}$ & $\begin{array}{l}\text { \# Correct } \\
\text { articles /Total of } \\
\text { articles }\end{array}$ \\
\hline 18 & 5 & 0 & $5 / 5$ & 11 & 1 & $10 / 11$ \\
\hline
\end{tabular}

Note: This script was filled up for every L2 student of experimental and control group. Errors different to articles and verbs, and sentences read from notes were not counted in this study. 


\section{Appendix J19}

Script of the video NAME: 19 EXP/Control and Topic: Fútbol

1 ) Messi y Neimar son las dos jugadores por Barcelona.

2) Messi es de Argentina.

3) Neimar es de Brasil.

This student produced: 3 sentences.

Errors found in sentence: 1

Global Accuracy

\begin{tabular}{|l|l|l|l|l|}
\hline Student & $\begin{array}{l}\text { \# Total of } \\
\text { clauses }\end{array}$ & $\begin{array}{l}\text { \# Clauses with } \\
\text { Errors }\end{array}$ & $\begin{array}{l}\text { \# Error-Free } \\
\text { Clauses }\end{array}$ & $\begin{array}{l}\text { \# Error-Free Clauses } \\
\text { / Total of Clauses }\end{array}$ \\
\hline 19 & 3 & 1 & 2 & $2 / 3$ \\
\hline
\end{tabular}

Specific Accuracy

\begin{tabular}{|l|l|l|l|l|l|l|}
\hline Student & $\begin{array}{l}\text { \# Total } \\
\text { of Verbs }\end{array}$ & $\begin{array}{l}\text { \# Verb } \\
\text { Errors }\end{array}$ & $\begin{array}{l}\text { \# Correct } \\
\text { verb /Total of } \\
\text { verbs }\end{array}$ & $\begin{array}{l}\text { \#Total } \\
\text { articles }\end{array}$ & $\begin{array}{l}\text { \# } \\
\text { Articles } \\
\text { Errors }\end{array}$ & $\begin{array}{l}\text { \# Correct } \\
\text { articles /Total of } \\
\text { articles }\end{array}$ \\
\hline 19 & 3 & 0 & $3 / 3$ & 1 & 1 & $0 / 1$ \\
\hline
\end{tabular}

Note: This script was filled up for every L2 student of experimental and control group. Errors different to articles and verbs, and sentences read from notes were not counted in this study. 
Appendix J20

Script of the video NAME: 20 EXP/Control and Topic: Los Carteles de la droga

1) En los Estados Unidos en 1998 fue creado el DEA o la administración para el control de la droga.

2) Es para parar las ventas y compras de drogas.

3) Tienen un propuesta de dos millones de dólares ahora.

4) En Méjico y Colombia los carteles son un problema.

5) Son los más grandes.

This student produced: 5 sentences.

Errors found in sentence: 1,3

Global Accuracy

\begin{tabular}{|l|l|l|l|l|}
\hline Student & $\begin{array}{l}\text { \# Total of } \\
\text { clauses }\end{array}$ & $\begin{array}{l}\text { \# Clauses with } \\
\text { Errors }\end{array}$ & $\begin{array}{l}\text { \# Error-Free } \\
\text { Clauses }\end{array}$ & $\begin{array}{l}\text { \# Error-Free Clauses } \\
\text { / Total of Clauses }\end{array}$ \\
\hline 20 & 5 & 2 & 3 & $3 / 5$ \\
\hline
\end{tabular}

Specific Accuracy

\begin{tabular}{|l|l|l|l|l|l|l|}
\hline Student & $\begin{array}{l}\text { \# Total } \\
\text { of Verbs }\end{array}$ & $\begin{array}{l}\text { \# Verb } \\
\text { Errors }\end{array}$ & $\begin{array}{l}\text { \# Correct } \\
\text { verb /Total of } \\
\text { verbs }\end{array}$ & $\begin{array}{l}\text { \#Total } \\
\text { articles }\end{array}$ & $\begin{array}{l}\# \\
\text { Articles } \\
\text { Errors }\end{array}$ & $\begin{array}{l}\text { \# Correct } \\
\text { articles /Total of } \\
\text { articles }\end{array}$ \\
\hline 20 & 7 & 0 & $7 / 7$ & 10 & 2 & $8 / 10$ \\
\hline
\end{tabular}

Note: This script was filled up for every L2 student of experimental and control group. Errors different to articles and verbs, and sentences read from notes were not counted in this study. 


\section{Appendix J 21}

Script of the video NAME: 21 EXP/Control and Topic: Gaudi

1) Un tranvía lo golpeó.

2) Gaudi era inconsciente en la calle.

3) Nadie ayudó a Gaudí a causa de su apariencia.

This student produced: 3 sentences.

Errors found in sentence: 2

Global Accuracy

\begin{tabular}{|l|l|l|l|l|}
\hline Student & $\begin{array}{l}\text { \# Total of } \\
\text { clauses }\end{array}$ & $\begin{array}{l}\text { \# Clauses with } \\
\text { Errors }\end{array}$ & $\begin{array}{l}\text { \# Error-Free } \\
\text { Clauses }\end{array}$ & $\begin{array}{l}\text { \# Error-Free Clauses } \\
\text { / Total of Clauses }\end{array}$ \\
\hline 21 & 3 & 1 & 2 & $2 / 3$ \\
\hline
\end{tabular}

Specific Accuracy

\begin{tabular}{|l|l|l|l|l|l|l|}
\hline Student & $\begin{array}{l}\text { \# Total } \\
\text { of Verbs }\end{array}$ & $\begin{array}{l}\text { \# Verb } \\
\text { Errors }\end{array}$ & $\begin{array}{l}\text { \# Correct } \\
\text { verb /Total of } \\
\text { verbs }\end{array}$ & $\begin{array}{l}\text { \#Total } \\
\text { articles }\end{array}$ & $\begin{array}{l}\# \\
\text { Articles } \\
\text { Errors }\end{array}$ & $\begin{array}{l}\text { \# Correct } \\
\text { articles /Total of } \\
\text { articles }\end{array}$ \\
\hline 21 & 3 & 1 & $2 / 3$ & 2 & 0 & $2 / 2$ \\
\hline
\end{tabular}

Note: This script was filled up for every L2 student of experimental and control group. Errors different to articles and verbs, and sentences read from notes were not counted in this study. 


\section{Appendix J 22}

Script of the video NAME: 22 EXP/Control and Topic: Club Real Madrid

1) Juega en la liga.

2) La liga es la primera división de España.

3) EL Real Madrid ganó 32 veces, el copa del Rey 19 veces, y la copa de xxx 9 veces.

4) El equipo del Real Madrid juegan en el estadio Santiago Bernabéu.

5) Tiene una capacidad para ochenta y un mil personas.

This student produced: 5 sentences.

Errors found in sentence: 3,4

Global Accuracy

\begin{tabular}{|l|l|l|l|l|}
\hline Student & $\begin{array}{l}\text { \# Total of } \\
\text { clauses }\end{array}$ & $\begin{array}{l}\text { \# Clauses with } \\
\text { Errors }\end{array}$ & $\begin{array}{l}\text { \# Error-Free } \\
\text { Clauses }\end{array}$ & $\begin{array}{l}\text { \# Error-Free Clauses } \\
\text { / Total of Clauses }\end{array}$ \\
\hline 22 & 5 & 2 & 3 & $3 / 5$ \\
\hline
\end{tabular}

Specific Accuracy

\begin{tabular}{|l|l|l|l|l|l|l|}
\hline Student & $\begin{array}{l}\text { \# Total } \\
\text { of Verbs }\end{array}$ & $\begin{array}{l}\text { \# Verb } \\
\text { Errors }\end{array}$ & $\begin{array}{l}\text { \# Correct } \\
\text { verb /Total of } \\
\text { verbs }\end{array}$ & $\begin{array}{l}\text { \#Total } \\
\text { articles }\end{array}$ & $\begin{array}{l}\text { \# } \\
\text { Articles } \\
\text { Errors }\end{array}$ & $\begin{array}{l}\text { \# Correct } \\
\text { articles /Total of } \\
\text { articles }\end{array}$ \\
\hline 22 & 5 & 1 & $4 / 5$ & 12 & 1 & $11 / 12$ \\
\hline
\end{tabular}

Note: This script was filled up for every L2 student of experimental and control group. Errors different to articles and verbs, and sentences read from notes were not counted in this study. 
Appendix J23

Script of the video NAME: 23 EXP/Control and Topic: Las Festividades de

Puerto Rico

1) Las máscaras tienen curenos largos y dientes afilados.

2) Otro de los festividades más importantes de Puerto Rico es la navidad.

3)La navidad es una época de unión y felicidad.

4)Grupos de familias y amigos forman una parranda.

5)En las parrandas se canta para otras personas.

This student produced: 5 sentences.

Errors found in sentence: 2

Global Accuracy

\begin{tabular}{|l|l|l|l|l|}
\hline Student & $\begin{array}{l}\text { \# Total of } \\
\text { clauses }\end{array}$ & $\begin{array}{l}\text { \# Clauses with } \\
\text { Errors }\end{array}$ & $\begin{array}{l}\text { \# Error-Free } \\
\text { Clauses }\end{array}$ & $\begin{array}{l}\text { \# Error-Free Clauses } \\
\text { / Total of Clauses }\end{array}$ \\
\hline 23 & 5 & 1 & 4 & $4 / 5$ \\
\hline
\end{tabular}

Specific Accuracy

\begin{tabular}{|l|l|l|l|l|l|l|}
\hline Student & $\begin{array}{l}\text { \# Total } \\
\text { of Verbs }\end{array}$ & $\begin{array}{l}\text { \# Verb } \\
\text { Errors }\end{array}$ & $\begin{array}{l}\text { \# Correct } \\
\text { verb /Total of } \\
\text { verbs }\end{array}$ & $\begin{array}{l}\text { \#Total } \\
\text { articles }\end{array}$ & $\begin{array}{l}\text { \# } \\
\text { Articles } \\
\text { Errors }\end{array}$ & $\begin{array}{l}\text { \# Correct } \\
\text { articles /Total of } \\
\text { articles }\end{array}$ \\
\hline 23 & 5 & 0 & $5 / 5$ & 7 & 1 & $6 / 7$ \\
\hline
\end{tabular}

Note: This script was filled up for every L2 student of experimental and control group. Errors different to articles and verbs, and sentences read from notes were not counted in this study. 
Appendix J 24

Script of the video NAME: 24 EXP/Control and Topic: La comida de Puerto

Rico

1) Este grupo trajo muchos alimentos.

2) Platos nuevos ha sido incorporados.

3) Muchos platos contenían las carnes.

4) La carne de cerdo es muy popular.

5) El asado es el plato tradicional de Puerto Rico en la Navidad.

This student produced: 5 sentences.

Errors found in sentence: 2

Global Accuracy

\begin{tabular}{|l|l|l|l|l|}
\hline Student & $\begin{array}{l}\text { \# Total of } \\
\text { clauses }\end{array}$ & $\begin{array}{l}\text { \# Clauses with } \\
\text { Errors }\end{array}$ & $\begin{array}{l}\text { \# Error-Free } \\
\text { Clauses }\end{array}$ & $\begin{array}{l}\text { \# Error-Free Clauses } \\
\text { / Total of Clauses }\end{array}$ \\
\hline 24 & 5 & 1 & 4 & $4 / 5$ \\
\hline
\end{tabular}

Specific Accuracy

\begin{tabular}{|l|l|l|l|l|l|l|}
\hline Student & $\begin{array}{l}\text { \# Total } \\
\text { of Verbs }\end{array}$ & $\begin{array}{l}\text { \# Verb } \\
\text { Errors }\end{array}$ & $\begin{array}{l}\text { \# Correct } \\
\text { verb /Total of } \\
\text { verbs }\end{array}$ & $\begin{array}{l}\text { \#Total } \\
\text { articles }\end{array}$ & $\begin{array}{l}\# \\
\text { Articles } \\
\text { Errors }\end{array}$ & $\begin{array}{l}\text { \# Correct } \\
\text { articles /Total of } \\
\text { articles }\end{array}$ \\
\hline 24 & 6 & 1 & $5 / 6$ & 5 & 0 & $5 / 5$ \\
\hline
\end{tabular}

Note: This script was filled up for every L2 student of experimental and control group. Errors different to articles and verbs, and sentences read from notes were not counted in this study. 
Appendix J 25

Script of the video NAME: 25 EXP/Control and Topic: Carteles de la Droga

1) Los carteles son heroicos.

2) El año pasado en Méjico el cartel asesinan a 7 personas.

3) Muestran xxxxx para crear miedo en el público y los oficiales del gobierno.

This student produced: 3 sentences.

Errors found in sentence: 2

Global Accuracy

\begin{tabular}{|l|l|l|l|l|}
\hline Student & $\begin{array}{l}\text { \# Total of } \\
\text { clauses }\end{array}$ & $\begin{array}{l}\text { \# Clauses with } \\
\text { Errors }\end{array}$ & $\begin{array}{l}\text { \# Error-Free } \\
\text { Clauses }\end{array}$ & $\begin{array}{l}\text { \# Error-Free Clauses } \\
\text { / Total of Clauses }\end{array}$ \\
\hline 25 & 3 & 1 & 2 & $2 / 3$ \\
\hline
\end{tabular}

Specific Accuracy

\begin{tabular}{|l|l|l|l|l|l|l|}
\hline Student & $\begin{array}{l}\text { \# Total } \\
\text { of Verbs }\end{array}$ & $\begin{array}{l}\text { \# Verb } \\
\text { Errors }\end{array}$ & $\begin{array}{l}\text { \# Correct } \\
\text { verb /Total of } \\
\text { verbs }\end{array}$ & $\begin{array}{l}\text { \#Total } \\
\text { articles }\end{array}$ & $\begin{array}{l}\text { \# } \\
\text { Articles } \\
\text { Errors }\end{array}$ & $\begin{array}{l}\text { \# Correct } \\
\text { articles /Total of } \\
\text { articles }\end{array}$ \\
\hline 25 & 4 & 1 & $3 / 4$ & 6 & 0 & $6 / 6$ \\
\hline
\end{tabular}

Note: This script was filled up for every L2 student of experimental and control group. Errors different to articles and verbs, and sentences read from notes were not counted in this study. 
Appendix J 26

Script of the video NAME: $26 \quad$ EXP/Control and Topic: Obras de Gaudi

This student did not produce sentences, just read.

This student produced: 0 sentences.

Errors found in sentence: 0

Global Accuracy

\begin{tabular}{|l|l|l|l|l|}
\hline Student & $\begin{array}{l}\text { \# Total of } \\
\text { clauses }\end{array}$ & $\begin{array}{l}\text { \# Clauses with } \\
\text { Errors }\end{array}$ & $\begin{array}{l}\text { \# Error-Free } \\
\text { Clauses }\end{array}$ & $\begin{array}{l}\text { \# Error-Free Clauses } \\
\text { / Total of Clauses }\end{array}$ \\
\hline 26 & 0 & 0 & 0 & 0 \\
\hline
\end{tabular}

Specific Accuracy

\begin{tabular}{|l|l|l|l|l|l|l|}
\hline Student & $\begin{array}{l}\text { \# Total } \\
\text { of Verbs }\end{array}$ & $\begin{array}{l}\text { \# Verb } \\
\text { Errors }\end{array}$ & $\begin{array}{l}\text { \# Correct } \\
\text { verb /Total of } \\
\text { verbs }\end{array}$ & $\begin{array}{l}\text { \#Total } \\
\text { articles }\end{array}$ & $\begin{array}{l}\text { \# } \\
\text { Articles } \\
\text { Errors }\end{array}$ & $\begin{array}{l}\text { \# Correct } \\
\text { articles /Total of } \\
\text { articles }\end{array}$ \\
\hline 26 & 0 & 0 & 0 & 0 & 0 & 0 \\
\hline
\end{tabular}

Note: This script was filled up for every L2 student of experimental and control group. Errors different to articles and verbs, and sentences read from notes were not counted in this study. 
Appendix J 27

Script of the video NAME: 27 EXP/Control and Topic: Tradiciones de España

1) xxx no es un tipo de comida pero una forma de comer.

2) Es una pequeña porción de algo.

3) xxx significa comer $\underline{00}$ tapa diferente en cada bar.

4)El flamenco no es un baile.

5)Es un estilo musical con énfasis en la guitarra, la voz y la ritmo

This student produced: 5 sentences.

Errors found in sentence: 3,5

Global Accuracy

\begin{tabular}{|l|l|l|l|l|}
\hline Student & $\begin{array}{l}\text { \# Total of } \\
\text { clauses }\end{array}$ & $\begin{array}{l}\text { \# Clauses with } \\
\text { Errors }\end{array}$ & $\begin{array}{l}\text { \# Error-Free } \\
\text { Clauses }\end{array}$ & $\begin{array}{l}\text { \# Error-Free Clauses } \\
\text { / Total of Clauses }\end{array}$ \\
\hline 27 & 5 & 2 & 3 & $3 / 5$ \\
\hline
\end{tabular}

Specific Accuracy

\begin{tabular}{|l|l|l|l|l|l|l|}
\hline Student & $\begin{array}{l}\text { \# Total } \\
\text { of Verbs }\end{array}$ & $\begin{array}{l}\text { \# Verb } \\
\text { Errors }\end{array}$ & $\begin{array}{l}\text { \# Correct } \\
\text { verb /Total of } \\
\text { verbs }\end{array}$ & $\begin{array}{l}\text { \#Total } \\
\text { articles }\end{array}$ & $\begin{array}{l}\text { \# } \\
\text { Articles } \\
\text { Errors }\end{array}$ & $\begin{array}{l}\text { \# Correct } \\
\text { articles /Total of } \\
\text { articles }\end{array}$ \\
\hline 27 & 7 & 0 & $7 / 7$ & 9 & 2 & $7 / 9$ \\
\hline
\end{tabular}

Note: This script was filled up for every L2 student of experimental and control group. Errors different to articles and verbs, and sentences read from notes were not counted in this study. 
Appendix J 28

Script of the video NAME: 28 EXP/Control and Topic: Venezuela

1) $96 \%$ practican la catolicismo.

This student produced: 1 sentence.

Errors found in sentence: 1

Global Accuracy

\begin{tabular}{|l|l|l|l|l|}
\hline Student & $\begin{array}{l}\text { \# Total of } \\
\text { clauses }\end{array}$ & $\begin{array}{l}\text { \# Clauses with } \\
\text { Errors }\end{array}$ & $\begin{array}{l}\text { \# Error-Free } \\
\text { Clauses }\end{array}$ & $\begin{array}{l}\text { \# Error-Free Clauses } \\
\text { / Total of Clauses }\end{array}$ \\
\hline 28 & 1 & 1 & 0 & $0 / 1$ \\
\hline
\end{tabular}

Specific Accuracy

\begin{tabular}{|l|l|l|l|l|l|l|}
\hline Student & $\begin{array}{l}\text { \# Total } \\
\text { of Verbs }\end{array}$ & $\begin{array}{l}\text { \# Verb } \\
\text { Errors }\end{array}$ & $\begin{array}{l}\text { \# Correct } \\
\text { verb /Total of } \\
\text { verbs }\end{array}$ & $\begin{array}{l}\text { \#Total } \\
\text { articles }\end{array}$ & $\begin{array}{l}\text { \# } \\
\text { Articles } \\
\text { Errors }\end{array}$ & $\begin{array}{l}\text { \# Correct } \\
\text { articles /Total of } \\
\text { articles }\end{array}$ \\
\hline 28 & 1 & 0 & $1 / 1$ & 1 & 1 & $0 / 1$ \\
\hline
\end{tabular}

Note: This script was filled up for every L2 student of experimental and control group. Errors different to articles and verbs, and sentences read from notes were not counted in this study. 
Appendix J 29

Script of the video NAME: 29 EXP/Control and Topic: Venezuela Hallacas

1) Le recomiendo que ordene los hallacas.

This student produced: 1 sentence.

Errors found in sentence: 1

Global Accuracy

\begin{tabular}{|l|l|l|l|l|}
\hline Student & $\begin{array}{l}\text { \# Total of } \\
\text { clauses }\end{array}$ & $\begin{array}{l}\text { \# Clauses with } \\
\text { Errors }\end{array}$ & $\begin{array}{l}\text { \# Error-Free } \\
\text { Clauses }\end{array}$ & $\begin{array}{l}\text { \# Error-Free Clauses } \\
\text { / Total of Clauses }\end{array}$ \\
\hline 29 & 1 & 1 & 0 & $0 / 1$ \\
\hline
\end{tabular}

Specific Accuracy

\begin{tabular}{|l|l|l|l|l|l|l|}
\hline Student & $\begin{array}{l}\text { \# Total } \\
\text { of Verbs }\end{array}$ & $\begin{array}{l}\text { \# Verb } \\
\text { Errors }\end{array}$ & $\begin{array}{l}\text { \# Correct } \\
\text { verb /Total of } \\
\text { verbs }\end{array}$ & $\begin{array}{l}\text { \#Total } \\
\text { articles }\end{array}$ & $\begin{array}{l}\text { \# } \\
\text { Articles } \\
\text { Errors }\end{array}$ & $\begin{array}{l}\text { \# Correct } \\
\text { articles /Total of } \\
\text { articles }\end{array}$ \\
\hline 29 & 1 & 0 & $1 / 1$ & 1 & 1 & $0 / 1$ \\
\hline
\end{tabular}

Note: This script was filled up for every L2 student of experimental and control group. Errors different to articles and verbs, and sentences read from notes were not counted in this study. 
Appendix J 30

Script of the video NAME: 30 EXP/Control and Topic: Platos de comida peruana

This student did not produce sentences, just read.

This student produced: 0 sentences.

Errors found in sentence: 0

Global Accuracy

\begin{tabular}{|l|l|l|l|l|}
\hline Student & $\begin{array}{l}\text { \# Total of } \\
\text { clauses }\end{array}$ & $\begin{array}{l}\text { \# Clauses with } \\
\text { Errors }\end{array}$ & $\begin{array}{l}\text { \# Error-Free } \\
\text { Clauses }\end{array}$ & $\begin{array}{l}\text { \# Error-Free Clauses } \\
\text { / Total of Clauses }\end{array}$ \\
\hline 30 & 0 & 0 & 0 & $0 / 0$ \\
\hline
\end{tabular}

Specific Accuracy

\begin{tabular}{|l|l|l|l|l|l|l|}
\hline Student & $\begin{array}{l}\text { \# Total } \\
\text { of Verbs }\end{array}$ & $\begin{array}{l}\text { \# Verb } \\
\text { Errors }\end{array}$ & $\begin{array}{l}\text { \# Correct } \\
\text { verb /Total of } \\
\text { verbs }\end{array}$ & $\begin{array}{l}\text { \#Total } \\
\text { articles }\end{array}$ & $\begin{array}{l}\text { \# } \\
\text { Articles } \\
\text { Errors }\end{array}$ & $\begin{array}{l}\text { \# Correct } \\
\text { articles /Total of } \\
\text { articles }\end{array}$ \\
\hline 30 & 0 & 0 & 0 & 0 & 0 & $0 / 0$ \\
\hline
\end{tabular}

Note: This script was filled up for every L2 student of experimental and control group. Errors different to articles and verbs, and sentences read from notes were not counted in this study. 


\section{Appendix J 31}

Script of the video NAME: 31 EXP/Control and Topic: La masamorra morada

This student did not produce sentences, just read.

This student produced: 0 sentences.

Errors found in sentence: 0

Global Accuracy

\begin{tabular}{|l|l|l|l|l|}
\hline Student & $\begin{array}{l}\text { \# Total of } \\
\text { clauses }\end{array}$ & $\begin{array}{l}\text { \# Clauses with } \\
\text { Errors }\end{array}$ & $\begin{array}{l}\text { \# Error-Free } \\
\text { Clauses }\end{array}$ & $\begin{array}{l}\text { \# Error-Free Clauses } \\
\text { / Total of Clauses }\end{array}$ \\
\hline 31 & 0 & 0 & 0 & 0 \\
\hline
\end{tabular}

Specific Accuracy

\begin{tabular}{|l|l|l|l|l|l|l|}
\hline Student & $\begin{array}{l}\text { \# Total } \\
\text { of Verbs }\end{array}$ & $\begin{array}{l}\text { \# Verb } \\
\text { Errors }\end{array}$ & $\begin{array}{l}\text { \# Correct } \\
\text { verb /Total of } \\
\text { verbs }\end{array}$ & $\begin{array}{l}\text { \#Total } \\
\text { articles }\end{array}$ & $\begin{array}{l}\text { \# } \\
\text { Articles } \\
\text { Errors }\end{array}$ & $\begin{array}{l}\text { \# Correct } \\
\text { articles /Total of } \\
\text { articles }\end{array}$ \\
\hline 31 & 0 & 0 & 0 & 0 & 0 & 0 \\
\hline
\end{tabular}

Note: This script was filled up for every L2 student of experimental and control group. Errors different to articles and verbs, and sentences read from notes were not counted in this study. 


\section{Appendix $\mathbf{J} 32$}

Script of the video NAME: 32 EXP/Control and Topic: Los carteles Méjico y

\section{Colombia}

1) El cartel es muy famoso en Méjico y Colombia.

This student produced: 1 sentence.

Errors found in sentence: 0

Global Accuracy

\begin{tabular}{|l|l|l|l|l|}
\hline Student & $\begin{array}{l}\text { \# Total of } \\
\text { clauses }\end{array}$ & $\begin{array}{l}\text { \# Clauses with } \\
\text { Errors }\end{array}$ & $\begin{array}{l}\text { \# Error-Free } \\
\text { Clauses }\end{array}$ & $\begin{array}{l}\text { \# Error-Free Clauses } \\
\text { / Total of Clauses }\end{array}$ \\
\hline 32 & 1 & 0 & 1 & $1 / 1$ \\
\hline
\end{tabular}

Specific Accuracy

\begin{tabular}{|l|l|l|l|l|l|l|}
\hline Student & $\begin{array}{l}\text { \# Total } \\
\text { of Verbs }\end{array}$ & $\begin{array}{l}\text { \# Verb } \\
\text { Errors }\end{array}$ & $\begin{array}{l}\text { \# Correct } \\
\text { verb /Total of } \\
\text { verbs }\end{array}$ & $\begin{array}{l}\text { \#Total } \\
\text { articles }\end{array}$ & $\begin{array}{l}\text { \# } \\
\text { Articles } \\
\text { Errors }\end{array}$ & $\begin{array}{l}\text { \# Correct } \\
\text { articles /Total of } \\
\text { articles }\end{array}$ \\
\hline 32 & 1 & 0 & $1 / 1$ & 1 & 0 & $1 / 1$ \\
\hline
\end{tabular}

Note: This script was filled up for every L2 student of experimental and control group. Errors different to articles and verbs, and sentences read from notes were not counted in this study. 
Appendix J 33

Script of the video NAME: 33 EXP/Control and Topic: El gobierno de España

1) España tiene un gobierno tipo parlamento.

2) Es un sistema que comprende un monarca o rey y un presidente.

3) Los españoles votan por los políticos que los representan.

4) Ellos les ayudan con las problemas por ejemplo económicos y criminales.

5) Un monarca es un presidente no electo.

This student produced: 5 sentences.

Errors found in sentence: 4

Global Accuracy

\begin{tabular}{|l|l|l|l|l|}
\hline Student & $\begin{array}{l}\text { \# Total of } \\
\text { clauses }\end{array}$ & $\begin{array}{l}\text { \# Clauses with } \\
\text { Errors }\end{array}$ & $\begin{array}{l}\text { \# Error-Free } \\
\text { Clauses }\end{array}$ & $\begin{array}{l}\text { \# Error-Free Clauses } \\
\text { / Total of Clauses }\end{array}$ \\
\hline 33 & 5 & 1 & 4 & $4 / 5$ \\
\hline
\end{tabular}

Specific Accuracy

\begin{tabular}{|l|l|l|l|l|l|l|}
\hline Student & $\begin{array}{l}\text { \# Total } \\
\text { of Verbs }\end{array}$ & $\begin{array}{l}\text { \# Verb } \\
\text { Errors }\end{array}$ & $\begin{array}{l}\text { \# Correct } \\
\text { verb /Total of } \\
\text { verbs }\end{array}$ & $\begin{array}{l}\text { \#Total } \\
\text { articles }\end{array}$ & $\begin{array}{l}\# \\
\text { Articles } \\
\text { Errors }\end{array}$ & $\begin{array}{l}\text { \# Correct } \\
\text { articles /Total of } \\
\text { articles }\end{array}$ \\
\hline 33 & 6 & 0 & $6 / 6$ & 10 & 1 & $9 / 10$ \\
\hline
\end{tabular}

Note: This script was filled up for every L2 student of experimental and control group. Errors different to articles and verbs, and sentences read from notes were not counted in this study. 
Appendix $\mathbf{J} 34$

Script of the video NAME: 34 EXP/Control and Topic: $\quad$ AREPAS

This student did not produce sentences, just read.

This student produced: 0 sentences.

Errors found in sentence: 0

Global Accuracy

\begin{tabular}{|l|l|l|l|l|}
\hline Student & $\begin{array}{l}\text { \# Total of } \\
\text { clauses }\end{array}$ & $\begin{array}{l}\text { \# Clauses with } \\
\text { Errors }\end{array}$ & $\begin{array}{l}\text { \# Error-Free } \\
\text { Clauses }\end{array}$ & $\begin{array}{l}\text { \# Error-Free Clauses } \\
\text { / Total of Clauses }\end{array}$ \\
\hline 34 & 0 & 0 & 0 & $0 / 0$ \\
\hline
\end{tabular}

Specific Accuracy

\begin{tabular}{|l|l|l|l|l|l|l|}
\hline Student & $\begin{array}{l}\text { \# Total } \\
\text { of Verbs }\end{array}$ & $\begin{array}{l}\text { \# Verb } \\
\text { Errors }\end{array}$ & $\begin{array}{l}\text { \# Correct } \\
\text { verb /Total of } \\
\text { verbs }\end{array}$ & $\begin{array}{l}\text { \#Total } \\
\text { articles }\end{array}$ & $\begin{array}{l}\text { \# } \\
\text { Articles } \\
\text { Errors }\end{array}$ & $\begin{array}{l}\text { \# Correct } \\
\text { articles /Total of } \\
\text { articles }\end{array}$ \\
\hline 34 & 0 & 0 & 0 & 0 & 0 & $0 / 0$ \\
\hline
\end{tabular}

Note: This script was filled up for every L2 student of experimental and control group. Errors different to articles and verbs, and sentences read from notes were not counted in this study. 
Appendix J 35

Script of the video NAME: $35 \quad$ EXP/Control and Topic: $\quad$ AREPAS

This student did not produce sentences, just read.

This student produced: 0 sentences.

Errors found in sentence: 0

Global Accuracy

\begin{tabular}{|l|l|l|l|l|}
\hline Student & $\begin{array}{l}\text { \# Total of } \\
\text { clauses }\end{array}$ & $\begin{array}{l}\text { \# Clauses with } \\
\text { Errors }\end{array}$ & $\begin{array}{l}\text { \# Error-Free } \\
\text { Clauses }\end{array}$ & $\begin{array}{l}\text { \# Error-Free Clauses } \\
\text { / Total of Clauses }\end{array}$ \\
\hline 35 & 0 & 0 & 0 & $0 / 0$ \\
\hline
\end{tabular}

Specific Accuracy

\begin{tabular}{|l|l|l|l|l|l|l|}
\hline Student & $\begin{array}{l}\text { \# Total } \\
\text { of Verbs }\end{array}$ & $\begin{array}{l}\text { \# Verb } \\
\text { Errors }\end{array}$ & $\begin{array}{l}\text { \# Correct } \\
\text { verb /Total of } \\
\text { verbs }\end{array}$ & $\begin{array}{l}\text { \#Total } \\
\text { articles }\end{array}$ & $\begin{array}{l}\text { \# } \\
\text { Articles } \\
\text { Errors }\end{array}$ & $\begin{array}{l}\text { \# Correct } \\
\text { articles /Total of } \\
\text { articles }\end{array}$ \\
\hline 35 & 0 & 0 & 0 & 0 & 0 & $0 / 0$ \\
\hline
\end{tabular}

Note: This script was filled up for every L2 student of experimental and control group. Errors different to articles and verbs, and sentences read from notes were not counted in this study. 
Appendix J 36

Script of the video NAME: 36 EXP/Control and Topic: Historia antigua de España

1) Nuestra xxx es sobre España.

2) Mi parte es sobre una historia básica de España.

3) En el siglo XI antes de Cristo los finicios descrubrieron a España.

4)El imperio conquistó la península.

This student produced: 4 sentences.

Errors found in sentence: 3

Global Accuracy

\begin{tabular}{|l|l|l|l|l|}
\hline Student & $\begin{array}{l}\text { \# Total of } \\
\text { clauses }\end{array}$ & $\begin{array}{l}\text { \# Clauses with } \\
\text { Errors }\end{array}$ & $\begin{array}{l}\text { \# Error-Free } \\
\text { Clauses }\end{array}$ & $\begin{array}{l}\text { \# Error-Free Clauses } \\
\text { / Total of Clauses }\end{array}$ \\
\hline 36 & 4 & 1 & 3 & $3 / 4$ \\
\hline
\end{tabular}

Specific Accuracy

\begin{tabular}{|l|l|l|l|l|l|l|}
\hline Student & $\begin{array}{l}\text { \# Total } \\
\text { of Verbs }\end{array}$ & $\begin{array}{l}\text { \# Verb } \\
\text { Errors }\end{array}$ & $\begin{array}{l}\text { \# Correct } \\
\text { verb /Total of } \\
\text { verbs }\end{array}$ & $\begin{array}{l}\text { \#Total } \\
\text { articles }\end{array}$ & $\begin{array}{l}\text { \# } \\
\text { Articles } \\
\text { Errors }\end{array}$ & $\begin{array}{l}\text { \# Correct } \\
\text { articles /Total of } \\
\text { articles }\end{array}$ \\
\hline 36 & 4 & 1 & $3 / 4$ & 5 & 0 & $5 / 5$ \\
\hline
\end{tabular}

Note: This script was filled up for every L2 student of experimental and control group. Errors different to articles and verbs, and sentences read from notes were not counted in this study. 


\section{Appendix $\mathbf{J} 37$}

Script of the video NAME: 37 EXP/Control and Topic: Venezuela (Pabellón)

This student did not produce sentences, just read.

This student produced: 0 sentences.

Errors found in sentence: 0

Global Accuracy

\begin{tabular}{|l|l|l|l|l|}
\hline Student & $\begin{array}{l}\text { \# Total of } \\
\text { clauses }\end{array}$ & $\begin{array}{l}\text { \# Clauses with } \\
\text { Errors }\end{array}$ & $\begin{array}{l}\text { \# Error-Free } \\
\text { Clauses }\end{array}$ & $\begin{array}{l}\text { \# Error-Free Clauses } \\
\text { / Total of Clauses }\end{array}$ \\
\hline 37 & 0 & 0 & 0 & $0 / 0$ \\
\hline
\end{tabular}

Specific Accuracy

\begin{tabular}{|l|l|l|l|l|l|l|}
\hline Student & $\begin{array}{l}\text { \# Total } \\
\text { of Verbs }\end{array}$ & $\begin{array}{l}\text { \# Verb } \\
\text { Errors }\end{array}$ & $\begin{array}{l}\text { \# Correct } \\
\text { verb /Total of } \\
\text { verbs }\end{array}$ & $\begin{array}{l}\text { \#Total } \\
\text { articles }\end{array}$ & $\begin{array}{l}\text { \# } \\
\text { Articles } \\
\text { Errors }\end{array}$ & $\begin{array}{l}\text { \# Correct } \\
\text { articles /Total of } \\
\text { articles }\end{array}$ \\
\hline 37 & 0 & 0 & $0 / 0$ & 0 & 0 & $0 / 0$ \\
\hline
\end{tabular}

Note: This script was filled up for every L2 student of experimental and control group. Errors different to articles and verbs, and sentences read from notes were not counted in this study. 
Appendix J 38

Script of the video NAME: 39 EXP/Control and Topic: $\quad$ Gaudi

This student did not produce sentences, just read.

This student produced: 0 sentences.

Errors found in sentence: 0

Global Accuracy

\begin{tabular}{|l|l|l|l|l|}
\hline Student & $\begin{array}{l}\text { \# Total of } \\
\text { clauses }\end{array}$ & $\begin{array}{l}\text { \# Clauses with } \\
\text { Errors }\end{array}$ & $\begin{array}{l}\text { \# Error-Free } \\
\text { Clauses }\end{array}$ & $\begin{array}{l}\text { \# Error-Free Clauses } \\
\text { / Total of Clauses }\end{array}$ \\
\hline 38 & 0 & 0 & 0 & $0 / 0$ \\
\hline
\end{tabular}

Specific Accuracy

\begin{tabular}{|l|l|l|l|l|l|l|}
\hline Student & $\begin{array}{l}\text { \# Total } \\
\text { of Verbs }\end{array}$ & $\begin{array}{l}\text { \# Verb } \\
\text { Errors }\end{array}$ & $\begin{array}{l}\text { \# Correct } \\
\text { verb /Total of } \\
\text { verbs }\end{array}$ & $\begin{array}{l}\text { \#Total } \\
\text { articles }\end{array}$ & $\begin{array}{l}\text { \# } \\
\text { Articles } \\
\text { Errors }\end{array}$ & $\begin{array}{l}\text { \# Correct } \\
\text { articles /Total of } \\
\text { articles }\end{array}$ \\
\hline 38 & 0 & 0 & $0 / 0$ & 0 & 0 & $0 / 0$ \\
\hline
\end{tabular}

Note: This script was filled up for every L2 student of experimental and control group. Errors different to articles and verbs, and sentences read from notes were not counted in this study. 
Appendix J 39

Script of the video NAME: HW EXP/Control and Topic: Comida del Perú

This student did not produce sentences, just read.

This student produced: 0 sentences.

Errors found in sentence: 0

Global Accuracy

\begin{tabular}{|l|l|l|l|l|}
\hline Student & $\begin{array}{l}\text { \# Total of } \\
\text { clauses }\end{array}$ & $\begin{array}{l}\text { \# Clauses with } \\
\text { Errors }\end{array}$ & $\begin{array}{l}\text { \# Error-Free } \\
\text { Clauses }\end{array}$ & $\begin{array}{l}\text { \# Error-Free Clauses } \\
\text { / Total of Clauses }\end{array}$ \\
\hline 39 & 0 & 0 & 0 & $0 / 0$ \\
\hline
\end{tabular}

Specific Accuracy

\begin{tabular}{|l|l|l|l|l|l|l|}
\hline Student & $\begin{array}{l}\text { \# Total } \\
\text { of Verbs }\end{array}$ & $\begin{array}{l}\text { \# Verb } \\
\text { Errors }\end{array}$ & $\begin{array}{l}\text { \# Correct } \\
\text { verb /Total of } \\
\text { verbs }\end{array}$ & $\begin{array}{l}\text { \#Total } \\
\text { articles }\end{array}$ & $\begin{array}{l}\text { \# } \\
\text { Articles } \\
\text { Errors }\end{array}$ & $\begin{array}{l}\text { \# Correct } \\
\text { articles /Total of } \\
\text { articles }\end{array}$ \\
\hline 39 & 0 & 0 & $0 / 0$ & 0 & 0 & $0 / 0$ \\
\hline
\end{tabular}

Note: This script was filled up for every L2 student of experimental and control group. Errors different to articles and verbs, and sentences read from notes were not counted in this study. 
Appendix J 40

Script of the video NAME: 40 EXP/Control and Topic: El Cono Sur /Paraguay

1) Ese es el presidente.

This student produced: 1 sentence.

Errors found in sentence: 0

Global Accuracy

\begin{tabular}{|l|l|l|l|l|}
\hline Student & $\begin{array}{l}\text { \# Total of } \\
\text { clauses }\end{array}$ & $\begin{array}{l}\text { \# Clauses with } \\
\text { Errors }\end{array}$ & $\begin{array}{l}\text { \# Error-Free } \\
\text { Clauses }\end{array}$ & $\begin{array}{l}\text { \# Error-Free Clauses } \\
\text { / Total of Clauses }\end{array}$ \\
\hline 40 & 1 & 0 & 1 & $1 / 1$ \\
\hline
\end{tabular}

Specific Accuracy

\begin{tabular}{|l|l|l|l|l|l|l|}
\hline Student & $\begin{array}{l}\text { \# Total } \\
\text { of Verbs }\end{array}$ & $\begin{array}{l}\text { \# Verb } \\
\text { Errors }\end{array}$ & $\begin{array}{l}\text { \# Correct } \\
\text { verb /Total of } \\
\text { verbs }\end{array}$ & $\begin{array}{l}\text { \#Total } \\
\text { articles }\end{array}$ & $\begin{array}{l}\text { \# } \\
\text { Articles } \\
\text { Errors }\end{array}$ & $\begin{array}{l}\text { \# Correct } \\
\text { articles /Total of } \\
\text { articles }\end{array}$ \\
\hline 40 & 1 & 0 & $1 / 1$ & 1 & 0 & $1 / 1$ \\
\hline
\end{tabular}

Note: This script was filled up for every L2 student of experimental and control group. Errors different to articles and verbs, and sentences read from notes were not counted in this study. 
Appendix J 41

Script of the video NAME: 41 EXP/Control and Topic: El Cono Sur

This student did not produce sentences, just read.

This student produced: 0 sentences.

Errors found in sentence: 0

Global Accuracy

\begin{tabular}{|l|l|l|l|l|}
\hline Student & $\begin{array}{l}\text { \# Total of } \\
\text { clauses }\end{array}$ & $\begin{array}{l}\text { \# Clauses with } \\
\text { Errors }\end{array}$ & $\begin{array}{l}\text { \# Error-Free } \\
\text { Clauses }\end{array}$ & $\begin{array}{l}\text { \# Error-Free Clauses } \\
\text { / Total of Clauses }\end{array}$ \\
\hline 41 & 0 & 0 & 0 & $0 / 0$ \\
\hline
\end{tabular}

Specific Accuracy

\begin{tabular}{|l|l|l|l|l|l|l|}
\hline Student & $\begin{array}{l}\text { \# Total } \\
\text { of Verbs }\end{array}$ & $\begin{array}{l}\text { \# Verb } \\
\text { Errors }\end{array}$ & $\begin{array}{l}\text { \# Correct } \\
\text { verb /Total of } \\
\text { verbs }\end{array}$ & $\begin{array}{l}\text { \#Total } \\
\text { articles }\end{array}$ & $\begin{array}{l}\text { \# } \\
\text { Articles } \\
\text { Errors }\end{array}$ & $\begin{array}{l}\text { \# Correct } \\
\text { articles /Total of } \\
\text { articles }\end{array}$ \\
\hline 41 & 0 & 0 & $0 / 0$ & 0 & 0 & $0 / 0$ \\
\hline
\end{tabular}

Note: This script was filled up for every L2 student of experimental and control group. Errors different to articles and verbs, and sentences read from notes were not counted in this study. 
Appendix J 42

Script of the video NAME: 42 EXP/Control and Topic: La comida de

Ecuador

This student did not produce sentences, just read.

This student produced: 0 sentences.

Errors found in sentence: 0

Global Accuracy

\begin{tabular}{|l|l|l|l|l|}
\hline Student & $\begin{array}{l}\text { \# Total of } \\
\text { clauses }\end{array}$ & $\begin{array}{l}\text { \# Clauses with } \\
\text { Errors }\end{array}$ & $\begin{array}{l}\text { \# Error-Free } \\
\text { Clauses }\end{array}$ & $\begin{array}{l}\text { \# Error-Free Clauses } \\
\text { / Total of Clauses }\end{array}$ \\
\hline 42 & 0 & 0 & 0 & $0 / 0$ \\
\hline
\end{tabular}

Specific Accuracy

\begin{tabular}{|l|l|l|l|l|l|l|}
\hline Student & $\begin{array}{l}\text { \# Total } \\
\text { of Verbs }\end{array}$ & $\begin{array}{l}\text { \# Verb } \\
\text { Errors }\end{array}$ & $\begin{array}{l}\text { \# Correct } \\
\text { verb /Total of } \\
\text { verbs }\end{array}$ & $\begin{array}{l}\text { \#Total } \\
\text { articles }\end{array}$ & $\begin{array}{l}\text { \# } \\
\text { Articles } \\
\text { Errors }\end{array}$ & $\begin{array}{l}\text { \# Correct } \\
\text { articles /Total of } \\
\text { articles }\end{array}$ \\
\hline 42 & 0 & 0 & $0 / 0$ & 0 & 0 & $0 / 0$ \\
\hline
\end{tabular}

Note: This script was filled up for every L2 student of experimental and control group. Errors different to articles and verbs, and sentences read from notes were not counted in this study. 
Appendix J 43

Script of the video NAME: $43 \quad$ EXP/Control and Topic: $\quad$ Cuba

This student did not produce sentences, just read.

This student produced: 0 sentences.

Errors found in sentence: 0

Global Accuracy

\begin{tabular}{|l|l|l|l|l|}
\hline Student & $\begin{array}{l}\text { \# Total of } \\
\text { clauses }\end{array}$ & $\begin{array}{l}\text { \# Clauses with } \\
\text { Errors }\end{array}$ & $\begin{array}{l}\text { \# Error-Free } \\
\text { Clauses }\end{array}$ & $\begin{array}{l}\text { \# Error-Free Clauses } \\
\text { / Total of Clauses }\end{array}$ \\
\hline 43 & 0 & 0 & 0 & $0 / 0$ \\
\hline
\end{tabular}

Specific Accuracy

\begin{tabular}{|l|l|l|l|l|l|l|}
\hline Student & $\begin{array}{l}\text { \# Total } \\
\text { of Verbs }\end{array}$ & $\begin{array}{l}\text { \# Verb } \\
\text { Errors }\end{array}$ & $\begin{array}{l}\text { \# Correct } \\
\text { verb /Total of } \\
\text { verbs }\end{array}$ & $\begin{array}{l}\text { \#Total } \\
\text { articles }\end{array}$ & $\begin{array}{l}\# \\
\text { Articles } \\
\text { Errors }\end{array}$ & $\begin{array}{l}\text { \# Correct } \\
\text { articles /Total of } \\
\text { articles }\end{array}$ \\
\hline 43 & 0 & 0 & $0 / 0$ & 0 & 0 & $0 / 0$ \\
\hline
\end{tabular}

Note: This script was filled up for every L2 student of experimental and control group. Errors different to articles and verbs, and sentences read from notes were not counted in this study. 
Appendix $\mathbf{J} 44$

Script of the video NAME: $44 \quad$ EXP/Control and Topic: La comida de

Ecuador

This student did not produce sentences, just read.

This student produced: 0 sentences.

Errors found in sentence: 0

Global Accuracy

\begin{tabular}{|l|l|l|l|l|}
\hline Student & $\begin{array}{l}\text { \# Total of } \\
\text { clauses }\end{array}$ & $\begin{array}{l}\text { \# Clauses with } \\
\text { Errors }\end{array}$ & $\begin{array}{l}\text { \# Error-Free } \\
\text { Clauses }\end{array}$ & $\begin{array}{l}\text { \# Error-Free Clauses } \\
\text { / Total of Clauses }\end{array}$ \\
\hline 44 & 0 & 0 & 0 & $0 / 0$ \\
\hline
\end{tabular}

Specific Accuracy

\begin{tabular}{|l|l|l|l|l|l|l|}
\hline Student & $\begin{array}{l}\text { \# Total } \\
\text { of Verbs }\end{array}$ & $\begin{array}{l}\text { \# Verb } \\
\text { Errors }\end{array}$ & $\begin{array}{l}\text { \# Correct } \\
\text { verb /Total of } \\
\text { verbs }\end{array}$ & $\begin{array}{l}\text { \#Total } \\
\text { articles }\end{array}$ & $\begin{array}{l}\# \\
\text { Articles } \\
\text { Errors }\end{array}$ & $\begin{array}{l}\text { \# Correct } \\
\text { articles /Total of } \\
\text { articles }\end{array}$ \\
\hline 44 & 0 & 0 & $0 / 0$ & 0 & 0 & $0 / 0$ \\
\hline
\end{tabular}

Note: This script was filled up for every L2 student of experimental and control group. Errors different to articles and verbs, and sentences read from notes were not counted in this study. 


\section{Appendix J 45}

Script of the video NAME: 45 EXP/Control and Topic: Las corridas de toros

1) Se practica en España, Méjico y algunos otros países.

2) El mozo de espada. ¿Tú entiendes qué es un mozo de espada?

3) Es un niño de la espada.

4) El matador observa el toro.

5) Los picadores hice $x x x$.

This student produced: 5 sentences.

Errors found in sentence: 5

Global Accuracy

\begin{tabular}{|l|l|l|l|l|}
\hline Student & $\begin{array}{l}\text { \# Total of } \\
\text { clauses }\end{array}$ & $\begin{array}{l}\text { \# Clauses with } \\
\text { Errors }\end{array}$ & $\begin{array}{l}\text { \# Error-Free } \\
\text { Clauses }\end{array}$ & $\begin{array}{l}\text { \# Error-Free Clauses } \\
\text { / Total of Clauses }\end{array}$ \\
\hline 45 & 5 & 1 & 4 & $4 / 5$ \\
\hline
\end{tabular}

Specific Accuracy

\begin{tabular}{|l|l|l|l|l|l|l|}
\hline Student & $\begin{array}{l}\text { \# Total } \\
\text { of Verbs }\end{array}$ & $\begin{array}{l}\text { \# Verb } \\
\text { Errors }\end{array}$ & $\begin{array}{l}\text { \# Correct } \\
\text { verb /Total of } \\
\text { verbs }\end{array}$ & $\begin{array}{l}\text { \#Total } \\
\text { articles }\end{array}$ & $\begin{array}{l}\text { \# } \\
\text { Articles } \\
\text { Errors }\end{array}$ & $\begin{array}{l}\text { \# Correct } \\
\text { articles /Total of } \\
\text { articles }\end{array}$ \\
\hline 45 & 6 & 1 & $5 / 6$ & 7 & 0 & $7 / 7$ \\
\hline
\end{tabular}

Note: This script was filled up for every L2 student of experimental and control group. Errors different to articles and verbs, and sentences read from notes were not counted in this study. 


\section{Appendix J46}

Script of the video NAME: 46 /Control and Topic: Sanfermines

1) Toda la comida se cocin con productos frescos cultivados en el mercado.

2) Muchas personas beben vino y cervezas.

3) Se puede disfrutar en varios restaurantes y cantinas.

4) La música es una parte importante del festival.

5) La música se toca en las calles.

This student produced: 5 sentences.

Errors found in sentence: 1

Global Accuracy

\begin{tabular}{|l|l|l|l|l|}
\hline Student & $\begin{array}{l}\text { \# Total of } \\
\text { clauses }\end{array}$ & $\begin{array}{l}\text { \# Clauses with } \\
\text { Errors }\end{array}$ & $\begin{array}{l}\text { \# Error-Free } \\
\text { Clauses }\end{array}$ & $\begin{array}{l}\text { \# Error-Free Clauses } \\
\text { / Total of Clauses }\end{array}$ \\
\hline 46 & 5 & 1 & 4 & $4 / 5$ \\
\hline
\end{tabular}

Specific Accuracy

\begin{tabular}{|l|l|l|l|l|l|l|}
\hline Student & $\begin{array}{l}\text { \# Total } \\
\text { of Verbs }\end{array}$ & $\begin{array}{l}\text { \# Verb } \\
\text { Errors }\end{array}$ & $\begin{array}{l}\text { \# Correct } \\
\text { verb /Total of } \\
\text { verbs }\end{array}$ & $\begin{array}{l}\text { \#Total } \\
\text { articles }\end{array}$ & $\begin{array}{l}\text { \# } \\
\text { Articles } \\
\text { Errors }\end{array}$ & $\begin{array}{l}\text { \# Correct } \\
\text { articles /Total of } \\
\text { articles }\end{array}$ \\
\hline 46 & 7 & 1 & $6 / 7$ & 7 & 0 & $7 / 7$ \\
\hline
\end{tabular}

Note: This script was filled up for every L2 student of experimental and control group. Errors different to articles and verbs, and sentences read from notes were not counted in this study. 
Appendix J 47

Script of the video NAME: 47 EXP/Control and Topic: Sanfermines

1) Es el principal evento.

2) Hay muchas actividades durante los sanfermines.

This student produced: 2 sentences.

Errors found in sentence: 0

Global Accuracy

\begin{tabular}{|l|l|l|l|l|}
\hline Student & $\begin{array}{l}\text { \# Total of } \\
\text { clauses }\end{array}$ & $\begin{array}{l}\text { \# Clauses with } \\
\text { Errors }\end{array}$ & $\begin{array}{l}\text { \# Error-Free } \\
\text { Clauses }\end{array}$ & $\begin{array}{l}\text { \# Error-Free Clauses } \\
\text { / Total of Clauses }\end{array}$ \\
\hline 47 & 2 & 0 & 2 & $2 / 2$ \\
\hline
\end{tabular}

Specific Accuracy

\begin{tabular}{|l|l|l|l|l|l|l|}
\hline Student & $\begin{array}{l}\text { \# Total } \\
\text { of Verbs }\end{array}$ & $\begin{array}{l}\text { \# Verb } \\
\text { Errors }\end{array}$ & $\begin{array}{l}\text { \# Correct } \\
\text { verb /Total of } \\
\text { verbs }\end{array}$ & $\begin{array}{l}\text { \#Total } \\
\text { articles }\end{array}$ & $\begin{array}{l}\text { \# } \\
\text { Articles } \\
\text { Errors }\end{array}$ & $\begin{array}{l}\text { \# Correct } \\
\text { articles /Total of } \\
\text { articles }\end{array}$ \\
\hline 47 & 2 & 0 & $2 / 2$ & 2 & 0 & $2 / 2$ \\
\hline
\end{tabular}

Note: This script was filled up for every L2 student of experimental and control group. Errors different to articles and verbs, and sentences read from notes were not counted in this study. 


\section{Appendix $\mathbf{J} 48$}

Script of the video NAME: 48 EXP/Control and Topic: Festival del Sol

1) Se celebra cada 24 de junio por una semana.

2) Es una ceremonia religiosa.

3) Se llama el sapa inca.

4) El sapa inca es el xxx del Cuzco.

5) El sapa inca saluda y da gracias al sol.

This student produced: 5 sentences.

Errors found in sentence 0

Global Accuracy

\begin{tabular}{|l|l|l|l|l|}
\hline Student & $\begin{array}{l}\text { \# Total of } \\
\text { clauses }\end{array}$ & $\begin{array}{l}\text { \# Clauses with } \\
\text { Errors }\end{array}$ & $\begin{array}{l}\text { \# Error-Free } \\
\text { Clauses }\end{array}$ & $\begin{array}{l}\text { \# Error-Free Clauses } \\
\text { / Total of Clauses }\end{array}$ \\
\hline 48 & 5 & 0 & 5 & $5 / 5$ \\
\hline
\end{tabular}

Specific Accuracy

\begin{tabular}{|l|l|l|l|l|l|l|}
\hline Student & $\begin{array}{l}\text { \# Total } \\
\text { of Verbs }\end{array}$ & $\begin{array}{l}\text { \# Verb } \\
\text { Errors }\end{array}$ & $\begin{array}{l}\text { \# Correct } \\
\text { verb /Total of } \\
\text { verbs }\end{array}$ & $\begin{array}{l}\text { \#Total } \\
\text { articles }\end{array}$ & $\begin{array}{l}\text { \# } \\
\text { Articles } \\
\text { Errors }\end{array}$ & $\begin{array}{l}\text { \# Correct } \\
\text { articles /Total of } \\
\text { articles }\end{array}$ \\
\hline 48 & 6 & 0 & $6 / 6$ & 7 & 0 & $7 / 7$ \\
\hline
\end{tabular}

Note: This script was filled up for every L2 student of experimental and control group. Errors different to articles and verbs, and sentences read from notes were not counted in this study. 
Appendix J 49

Script of the video NAME: 49 EXP/Control and Topic: La comida de Ecuador

This student did not produce sentences, just read.

This student produced: 0 sentences.

Errors found in sentence: 0

Global Accuracy

\begin{tabular}{|l|l|l|l|l|}
\hline Student & $\begin{array}{l}\text { \# Total of } \\
\text { clauses }\end{array}$ & $\begin{array}{l}\text { \# Clauses with } \\
\text { Errors }\end{array}$ & $\begin{array}{l}\text { \# Error-Free } \\
\text { Clauses }\end{array}$ & $\begin{array}{l}\text { \# Error-Free Clauses } \\
\text { / Total of Clauses }\end{array}$ \\
\hline 49 & 0 & 0 & 0 & $0 / 0$ \\
\hline
\end{tabular}

Specific Accuracy

\begin{tabular}{|l|l|l|l|l|l|l|}
\hline Student & $\begin{array}{l}\text { \# Total } \\
\text { of Verbs }\end{array}$ & $\begin{array}{l}\text { \# Verb } \\
\text { Errors }\end{array}$ & $\begin{array}{l}\text { \# Correct } \\
\text { verb /Total of } \\
\text { verbs }\end{array}$ & $\begin{array}{l}\text { \#Total } \\
\text { articles }\end{array}$ & $\begin{array}{l}\text { \# } \\
\text { Articles } \\
\text { Errors }\end{array}$ & $\begin{array}{l}\text { \# Correct } \\
\text { articles /Total of } \\
\text { articles }\end{array}$ \\
\hline 49 & 0 & 0 & $0 / 0$ & 0 & 0 & $0 / 0$ \\
\hline
\end{tabular}

Note: This script was filled up for every L2 student of experimental and control group. Errors different to articles and verbs, and sentences read from notes were not counted in this study. 
Appendix J 50

Script of the video NAME: 50 EXP/Control and Topic: La corrida de toros

1) Las corridas de toros se utilizan para el deporte.

This student produced: 1 sentence.

Errors found in sentence: 0

Global Accuracy

\begin{tabular}{|l|l|l|l|l|}
\hline Student & $\begin{array}{l}\text { \# Total of } \\
\text { clauses }\end{array}$ & $\begin{array}{l}\text { \# Clauses with } \\
\text { Errors }\end{array}$ & $\begin{array}{l}\text { \# Error-Free } \\
\text { Clauses }\end{array}$ & $\begin{array}{l}\text { \# Error-Free Clauses } \\
\text { / Total of Clauses }\end{array}$ \\
\hline 50 & 1 & 0 & 0 & $1 / 1$ \\
\hline
\end{tabular}

Specific Accuracy

\begin{tabular}{|l|l|l|l|l|l|l|}
\hline Student & $\begin{array}{l}\text { \# Total } \\
\text { of Verbs }\end{array}$ & $\begin{array}{l}\text { \# Verb } \\
\text { Errors }\end{array}$ & $\begin{array}{l}\text { \# Correct } \\
\text { verb /Total of } \\
\text { verbs }\end{array}$ & $\begin{array}{l}\text { \#Total } \\
\text { articles }\end{array}$ & $\begin{array}{l}\# \\
\text { Articles } \\
\text { Errors }\end{array}$ & $\begin{array}{l}\text { \# Correct } \\
\text { articles /Total of } \\
\text { articles }\end{array}$ \\
\hline 50 & 1 & 0 & $1 / 1$ & 2 & 0 & $2 / 2$ \\
\hline
\end{tabular}

Note: This script was filled up for every L2 student of experimental and control group. Errors different to articles and verbs, and sentences read from notes were not counted in this study. 


\section{Appendix J 51}

Script of the video NAME: 51 EXP/Control and Topic: $\quad$ Los galápagos

This student did not produce sentences, just read.

This student produced: 0 sentences.

Errors found in sentence: 0

Global Accuracy

\begin{tabular}{|l|l|l|l|l|}
\hline Student & $\begin{array}{l}\text { \# Total of } \\
\text { clauses }\end{array}$ & $\begin{array}{l}\text { \# Clauses with } \\
\text { Errors }\end{array}$ & $\begin{array}{l}\text { \# Error-Free } \\
\text { Clauses }\end{array}$ & $\begin{array}{l}\text { \# Error-Free Clauses } \\
\text { / Total of Clauses }\end{array}$ \\
\hline 51 & 0 & 0 & 0 & $0 / 0$ \\
\hline
\end{tabular}

Specific Accuracy

\begin{tabular}{|l|l|l|l|l|l|l|}
\hline Student & $\begin{array}{l}\text { \# Total } \\
\text { of Verbs }\end{array}$ & $\begin{array}{l}\text { \# Verb } \\
\text { Errors }\end{array}$ & $\begin{array}{l}\text { \# Correct } \\
\text { verb /Total of } \\
\text { verbs }\end{array}$ & $\begin{array}{l}\text { \#Total } \\
\text { articles }\end{array}$ & $\begin{array}{l}\# \\
\text { Articles } \\
\text { Errors }\end{array}$ & $\begin{array}{l}\text { \# Correct } \\
\text { articles /Total of } \\
\text { articles }\end{array}$ \\
\hline 51 & 0 & 0 & $0 / 0$ & 0 & 0 & $0 / 0$ \\
\hline
\end{tabular}

Note: This script was filled up for every L2 student of experimental and control group. Errors different to articles and verbs, and sentences read from notes were not counted in this study. 


\section{Appendix $\mathbf{J} 52$}

Script of the video NAME: 52 EXP/Control and Topic: Los galápagos

This student did not produce sentences, just read.

This student produced: 0 sentences.

Errors found in sentence: 0

Global Accuracy

\begin{tabular}{|l|l|l|l|l|}
\hline Student & $\begin{array}{l}\text { \# Total of } \\
\text { clauses }\end{array}$ & $\begin{array}{l}\text { \# Clauses with } \\
\text { Errors }\end{array}$ & $\begin{array}{l}\text { \# Error-Free } \\
\text { Clauses }\end{array}$ & $\begin{array}{l}\text { \# Error-Free Clauses } \\
\text { / Total of Clauses }\end{array}$ \\
\hline 52 & 0 & 0 & 0 & $0 / 0$ \\
\hline
\end{tabular}

Specific Accuracy

\begin{tabular}{|l|l|l|l|l|l|l|}
\hline Student & $\begin{array}{l}\text { \# Total } \\
\text { of Verbs }\end{array}$ & $\begin{array}{l}\text { \# Verb } \\
\text { Errors }\end{array}$ & $\begin{array}{l}\text { \# Correct } \\
\text { verb /Total of } \\
\text { verbs }\end{array}$ & $\begin{array}{l}\text { \#Total } \\
\text { articles }\end{array}$ & $\begin{array}{l}\text { \# } \\
\text { Articles } \\
\text { Errors }\end{array}$ & $\begin{array}{l}\text { \# Correct } \\
\text { articles /Total of } \\
\text { articles }\end{array}$ \\
\hline 52 & 0 & 0 & $0 / 0$ & 0 & 0 & $0 / 0$ \\
\hline
\end{tabular}

Note: This script was filled up for every L2 student of experimental and control group. Errors different to articles and verbs, and sentences read from notes were not counted in this study. 


\section{Appendix $\mathrm{J} 53$}

Script of the video NAME: $53 \quad$ EXP/Control and Topic: El Cono Sur Chile

1) Me llamo Jonathan.

2) Mi xxx es Chile.

This student produced 2 sentences.

Errors found in sentence: 0

Global Accuracy

\begin{tabular}{|l|l|l|l|l|}
\hline Student & $\begin{array}{l}\text { \# Total of } \\
\text { clauses }\end{array}$ & $\begin{array}{l}\text { \# Clauses with } \\
\text { Errors }\end{array}$ & $\begin{array}{l}\text { \# Error-Free } \\
\text { Clauses }\end{array}$ & $\begin{array}{l}\text { \# Error-Free Clauses } \\
\text { / Total of Clauses }\end{array}$ \\
\hline 53 & 1 & 0 & 1 & $1 / 1$ \\
\hline
\end{tabular}

Specific Accuracy

\begin{tabular}{|l|l|l|l|l|l|l|}
\hline Student & $\begin{array}{l}\text { \# Total } \\
\text { of Verbs }\end{array}$ & $\begin{array}{l}\text { \# Verb } \\
\text { Errors }\end{array}$ & $\begin{array}{l}\text { \# Correct } \\
\text { verb /Total of } \\
\text { verbs }\end{array}$ & $\begin{array}{l}\text { \#Total } \\
\text { articles }\end{array}$ & $\begin{array}{l}\# \\
\text { Articles } \\
\text { Errors }\end{array}$ & $\begin{array}{l}\text { \# Correct } \\
\text { articles /Total of } \\
\text { articles }\end{array}$ \\
\hline 53 & 2 & 0 & $2 / 2$ & 0 & 0 & $0 / 0$ \\
\hline
\end{tabular}

Note: This script was filled up for every L2 student of experimental and control group. Errors different to articles and verbs, and sentences read from notes were not counted in this study. 


\section{Appendix J 54}

Script of the video NAME: 54 EXP/Control and Topic: Sanfermines

1) Hoy presentamos los sanfermines.

2) Los xxx son un festival religioso, festival en honor a San Fermín.

3) Se celebra en Pamplona España.

4) La ropa es muy importante..

5) Es tradición llevar el traje.

This student produced: 5 sentences.

Errors found in sentence: 0

Global Accuracy

\begin{tabular}{|l|l|l|l|l|}
\hline Student & $\begin{array}{l}\text { \# Total of } \\
\text { clauses }\end{array}$ & $\begin{array}{l}\text { \# Clauses with } \\
\text { Errors }\end{array}$ & $\begin{array}{l}\text { \# Error-Free } \\
\text { Clauses }\end{array}$ & $\begin{array}{l}\text { \# Error-Free Clauses } \\
\text { / Total of Clauses }\end{array}$ \\
\hline 54 & 5 & 0 & 5 & $5 / 5$ \\
\hline
\end{tabular}

Specific Accuracy

\begin{tabular}{|l|l|l|l|l|l|l|}
\hline Student & $\begin{array}{l}\text { \# Total } \\
\text { of Verbs }\end{array}$ & $\begin{array}{l}\text { \# Verb } \\
\text { Errors }\end{array}$ & $\begin{array}{l}\text { \# Correct } \\
\text { verb /Total of } \\
\text { verbs }\end{array}$ & $\begin{array}{l}\text { \#Total } \\
\text { articles }\end{array}$ & $\begin{array}{l}\text { \# } \\
\text { Articles } \\
\text { Errors }\end{array}$ & $\begin{array}{l}\text { \# Correct } \\
\text { articles /Total of } \\
\text { articles }\end{array}$ \\
\hline 54 & 6 & 0 & $6 / 6$ & 5 & 0 & $5 / 5$ \\
\hline
\end{tabular}

Note: This script was filled up for every L2 student of experimental and control group. Errors different to articles and verbs, and sentences read from notes were not counted in this study. 


\section{Appendix J 55}

Script of the video NAME: 55 EXP/Control and Topic: Takamaki

1) Todo el pueblo va a campo grande para la lucha.

2) La mayoría de los luchadores son borrachos.

3) Porque ellos beben mucho alcohol antes de la lucha.

4) Los hombres luchan.

5) Las mujeres y los niños luchan también.

This student produced: 5 sentences.

Errors found in sentence: 2

Global Accuracy

\begin{tabular}{|l|l|l|l|l|}
\hline Student & $\begin{array}{l}\text { \# Total of } \\
\text { clauses }\end{array}$ & $\begin{array}{l}\text { \# Clauses with } \\
\text { Errors }\end{array}$ & $\begin{array}{l}\text { \# Error-Free } \\
\text { Clauses }\end{array}$ & $\begin{array}{l}\text { \# Error-Free Clauses } \\
\text { / Total of Clauses }\end{array}$ \\
\hline 55 & 5 & 1 & 4 & $4 / 5$ \\
\hline
\end{tabular}

Specific Accuracy

\begin{tabular}{|l|l|l|l|l|l|l|}
\hline Student & $\begin{array}{l}\text { \# Total } \\
\text { of Verbs }\end{array}$ & $\begin{array}{l}\text { \# Verb } \\
\text { Errors }\end{array}$ & $\begin{array}{l}\text { \# Correct } \\
\text { verb /Total of } \\
\text { verbs }\end{array}$ & $\begin{array}{l}\text { \#Total } \\
\text { articles }\end{array}$ & $\begin{array}{l}\text { \# } \\
\text { Articles } \\
\text { Errors }\end{array}$ & $\begin{array}{l}\text { \# Correct } \\
\text { articles /Total of } \\
\text { articles }\end{array}$ \\
\hline 55 & 5 & 1 & $4 / 5$ & 8 & 0 & $8 / 8$ \\
\hline
\end{tabular}

Note: This script was filled up for every L2 student of experimental and control group. Errors different to articles and verbs, and sentences read from notes were not counted in this study. 


\section{Appendix J56}

Script of the video NAME: 56 EXP/Control and Topic: La ciudad de Madrid

1) Esta es la bandera de Madrid.

2) Córdova construyó un palacio en el sitio de Madrid.

3) El sitio se llamaba Maderit.

4) Con el tiempo el nombre cambió a Madrid.

5) Muchos de los edificios medievales fueron construidos xxx.

This student produced: 5 sentences.

Errors found in sentence: 0

Global Accuracy

\begin{tabular}{|l|l|l|l|l|}
\hline Student & $\begin{array}{l}\text { \# Total of } \\
\text { clauses }\end{array}$ & $\begin{array}{l}\text { \# Clauses with } \\
\text { Errors }\end{array}$ & $\begin{array}{l}\text { \# Error-Free } \\
\text { Clauses }\end{array}$ & $\begin{array}{l}\text { \# Error-Free Clauses } \\
\text { / Total of Clauses }\end{array}$ \\
\hline 56 & 5 & 0 & 5 & $5 / 5$ \\
\hline
\end{tabular}

Specific Accuracy

\begin{tabular}{|l|l|l|l|l|l|l|}
\hline Student & $\begin{array}{l}\text { \# Total } \\
\text { of Verbs }\end{array}$ & $\begin{array}{l}\text { \# Verb } \\
\text { Errors }\end{array}$ & $\begin{array}{l}\text { \# Correct } \\
\text { verb /Total of } \\
\text { verbs }\end{array}$ & $\begin{array}{l}\text { \#Total } \\
\text { articles }\end{array}$ & $\begin{array}{l}\text { \# } \\
\text { Articles } \\
\text { Errors }\end{array}$ & $\begin{array}{l}\text { \# Correct } \\
\text { articles /Total of } \\
\text { articles }\end{array}$ \\
\hline 56 & 6 & 0 & $6 / 6$ & 7 & 0 & $7 / 7$ \\
\hline
\end{tabular}

Note: This script was filled up for every L2 student of experimental and control group. Errors different to articles and verbs, and sentences read from notes were not counted in this study. 


\section{Appendix J57}

Script of the video NAME: 57 EXP/Control and Topic: El fútbol

\section{1) 00 fútbol es muy importante.}

This student produced: 1 sentence.

Errors found in sentence: 1

Global Accuracy

\begin{tabular}{|l|l|l|l|l|}
\hline Student & $\begin{array}{l}\text { \# Total of } \\
\text { clauses }\end{array}$ & $\begin{array}{l}\text { \# Clauses with } \\
\text { Errors }\end{array}$ & $\begin{array}{l}\text { \# Error-Free } \\
\text { Clauses }\end{array}$ & $\begin{array}{l}\text { \# Error-Free Clauses } \\
\text { / Total of Clauses }\end{array}$ \\
\hline 57 & 1 & 0 & 1 & $1 / 1$ \\
\hline
\end{tabular}

Specific Accuracy

\begin{tabular}{|l|l|l|l|l|l|l|}
\hline Student & $\begin{array}{l}\text { \# Total } \\
\text { of Verbs }\end{array}$ & $\begin{array}{l}\text { \# Verb } \\
\text { Errors }\end{array}$ & $\begin{array}{l}\text { \# Correct } \\
\text { verb /Total of } \\
\text { verbs }\end{array}$ & $\begin{array}{l}\text { \#Total } \\
\text { articles }\end{array}$ & $\begin{array}{l}\text { \# } \\
\text { Articles } \\
\text { Errors }\end{array}$ & $\begin{array}{l}\text { \# Correct } \\
\text { articles /Total of } \\
\text { articles }\end{array}$ \\
\hline 57 & 1 & 0 & $1 / 1$ & 1 & 1 & $0 / 1$ \\
\hline
\end{tabular}

Note: This script was filled up for every L2 student of experimental and control group. Errors different to articles and verbs, and sentences read from notes were not counted in this study. 